UNIVERSIDADE FEDERAL DE MINAS GERAIS

ESCOLA DE ENFERMAGEM

MESTRADO EM SAÚDE E ENFERMAGEM

\title{
os sentidos do Trabalho para profissionais da saúde do CTI de um Hospital universitario
}

Carolina da Silva Caram

Belo Horizonte, 
Carolina da Silva Caram

OS SENTIDOS DO TRABALHO PARA PROFISSIONAIS DA SAÚDE DO CTI DE UM HOSPITAL UNIVERSITÁRIO

Dissertação apresentada ao Curso de Mestrado da Escola de Enfermagem da Universidade Federal de Minas Gerais.

Área de concentração: Saúde e Enfermagem

Orientadora: Profa. Dra. Maria José Menezes Brito

Belo Horizonte, 2013 


\section{Caram, Carolina da Silva.}

C259s Os sentidos do trabalho para profissionais da saúde do CTI de um Hospital Universitário [manuscrito]. / Carolina da Silva Caram. - - Belo Horizonte: 2013.

131f.: il.

Orientadora: Maria José Menezes Brito.

Área de concentração: Saúde e Enfermagem.

Dissertação (mestrado): Universidade Federal de Minas Gerais, Escola de Enfermagem.

1. Unidades de Terapia Intensiva. 2. Recursos Humanos em Saúde. 3. Trabalho. 4. Valor Social. 5. Enfermagem. 6. Dissertações Acadêmicas. I. Brito, Maria José Menezes. II. Universidade Federal de Minas Gerais, Escola de Enfermagem. III. Título.

NLM: WX 218 
Dedico este trabalho a todos os meus familiares e amigos que contribuíram para o meu crescimento e me acompanharam durante essa prazerosa vivência 
Ao papai, mamãe e Gui por serem minha maior plateia e torcerem sempre, vivenciando minhas vitórias como se fossem deles e me amparando nos momentos de fraqueza. Amor demais!

À minha amiga-mãe-orientadora Prof. Maria José Menezes Brito, por ser muito mais do que um exemplo a ser seguido, com quem aprendi que a caminhada pode ser prazerosa, feliz e muito produtiva sempre ao lado das pessoas, com amor, carinho e amizade. Obrigada por acreditar acima de tudo, por todos os ensinamentos e por compartilhar essa sabedoria, só pode ser um anjo!

Ao Greg pela compreensão das ausências e pelo preenchimento dos momentos de distração, além de ser minha motivação. Obrigada meu amor!

Aos professores da escola de enfermagem da UFMG, especialmente, à Prof. Marília Alves que sempre tem uma palavra na hora certa e por "preencher" a sala 514 e à Prof. Cláudia Penna por ter um papel importante no meu crescimento pessoal, pelos momentos de grande aprendizado em suas disciplinas que nunca vou me esquecer (Antropologia da Saúde é um divisor de águas) e dos momentos de descontração.

Aos amigos do mestrado, em especial Pâmela e Lane, pelos desesperos, risadas, fofocas, mas acima de tudo uma amizade importantíssima para dar leveza à trajetória.

Aos amigos do NUPAE e da Escola de Enfermagem: Daniele Soares, Heloiza Rennó, Tereza Cristina Peixoto e Beatriz Caçador (nossa viagem para Floripa será inesquecível), Amanda Soares, Fabiana Lopes, Camila Campos, Rafael Carvalho, Lucas Lobato, Glaucia, Roberta Souto, Ludmila Rocha, Andrea Guerra, Meiriele Tavares, Hellen Ribeiro, Valéria Cristina, Letícia Freitas.

Às anjas da minha vida, Lívia Montenegro por compartilhar dos sentimentos, pela amizade e por ser sempre generosa; À Lílian Rezende pela amizade, trabalho árduo, confusões, apoio e ajuda sempre; À Heloiza Rennó por sempre ter uma palavra acolhedora e por acreditar no meu potencial; À Beatriz Caçador por ser a flor mais colorida do jardim, pela amizade, por ser exemplo de força, dedicação e compromisso; À Marcela e Samara por serem sempre 
disponíveis e por terem carinho com o meu trabalho, sou imensamente grata a vocês; À Cecília, Dani e Hanna por estarem presentes, pela sensibilidade e carinho.

Às minhas amigas da vida Elaine Campos, Thaína Alves, Shaiana Alves, Ana Claúdia Reis, Ana Luiza Gomes, Lorena Lara e Luciana Milagres.

À minha família Caram e Silva pela torcida especial e, principalmente, à Vovó Geralda por me colocar sempre em suas orações e pelo cuidado.

À CAPES por me oferecer subsídios para "simplesmente” estudar.

À Deus por colocar benções na minha vida, por me dar força e coragem para realizar esse sonho e acima de tudo por colocar essas pessoas na minha vida! 
CARAM, C.S. Os sentidos do trabalho para profissionais da saúde do CTI de um Hospital Universitário. 2013. -f. Dissertação [Mestrado em Enfermagem] - Escola de Enfermagem, Universidade Federal de Minas Gerais, Belo Horizonte, 2013.

As pessoas dão vida e dinâmica à organização, ou seja, a subjetividade das pessoas movimenta o trabalho e as relações inerentes a ela. Na saúde o trabalho se diferencia dos demais, principalmente, no que concerne às relações interpessoais e à subjetividade dos trabalhadores e clientes. Os Centros de Terapia Intensiva nos quais atuam profissionais de diferentes categorias na prestação de cuidados intensivos à pacientes em estados críticos de saúde, possui um modo de vida singular que faz com que os profissionais atribuam sentidos ao trabalho de forma diferenciada. Para que o serviço prestado seja coerente tanto com a organização quanto com os princípios e valores do profissional é necessário que os trabalhadores atribuam sentidos ao trabalho realizado. O termo sentido refere-se à compreensão da razão de ser dos profissionais ao realizarem seu trabalho. Visto o exposto, este estudo teve como objetivo compreender os sentidos do trabalho para profissionais da saúde que atuam no CTI de um hospital universitário em Belo Horizonte. Trata-se de um estudo de natureza qualitativa desenvolvido em um Centro de Terapia Intensiva (CTI) de um Hospital Universitário em Belo Horizonte, Minas Gerais. Os sujeitos da pesquisa foram 31 profissionais da saúde que atuavam na assistência direta ao paciente no CTI, sendo eles: enfermeiros, técnicos de enfermagem, médicos, fisioterapeutas, fonoaudiólogos, nutricionistas e psicólogos. Os dados foram coletados após aprovação do projeto nos Comitês de Ética em Pesquisa das instituições envolvidas e após a assinatura do Termo de Consentimento Livre e Esclarecido (TCLE) pelos sujeitos. A coleta foi realizada em dois momentos: 1) questionário para identificar o perfil dos sujeitos; 2) entrevista com roteiro semiestruturado e aplicação da Técnica do Gibi. A entrevista juntamente a Técnica do Gibi foram submetidas à Análise de Conteúdo de Bardin. Os resultados foram elaborados tomando-se como base as dimensões do sentido do trabalho: individual, social, organizacional e fazer cotidiano. A dimensão individual está relacionada com aspectos profissionais dos sujeitos que possuem proporções significativas na vida particular dele. É nesta dimensão que o indivíduo valoriza o reconhecimento profissional que recebe dos outros e de si mesmo do trabalho que realiza. Ademais, ele percebe também que por meio do trabalho ele é capaz de crescer pessoal e profissionalmente além de se satisfazer com a prática profissional. A dimensão organizacional está associada à identificação que o profissional tem com a organização. . Dessa forma, foram observados nessa dimensão a estrutura organizacional, o trabalho em equipe, os 
relacionamentos interpessoais inerentes ao trabalho e o papel desses na vida social do profissional, o comprometimento organizacional e o reconhecimento da instituição devido ao trabalho prestado. A dimensão fazer cotidiano enfoca o trabalho profissional em ato, ou seja, o fazer profissional e os resultantes do mesmo, tais como: o prazer em ver o seu trabalho realizado e a recuperação do paciente, a percepção da efetivação e utilidade do trabalho em ato. Além das formas de realizar o trabalho e de tratar o indivíduo com singularidade e humanidade. A dimensão social analisa o valor social do trabalho bem como a inserção dele na sociedade. Nesta seção, buscou-se apresentar como o profissional enxerga a contribuição do seu trabalho para a sociedade. A compreensão do sentido do trabalho para profissionais da saúde que atuam em um CTI de um Hospital Universitário no qual atuam diferentes categoriais profissionais que se articulam e ressignificam o trabalho torna-se relevante na organização do processo de trabalho e das práticas gerencias. Além disso, pode contribuir para projetar meios de revalorizar o trabalho e lhe dar sentido, de forma que os profissionais atuem em consonância com os objetivos organizacionais, evitando assim, os desvios de comportamentos que comprometem a assistência e também, contribuir para o resgate do ser humano em sua dimensão subjetiva nas práticas em saúde.

Palavra chave: Unidade de Terapia Intensiva; Recursos Humanos em Saúde; Enfermagem; Trabalho. 
CARAM, CS. The meanings of work for health professionals from the ICU of a university hospital. In 2013. 131f. Dissertation [Master] - School of Nursing, Federal University of Minas Gerais, Belo Horizonte, 2013.

The People give life and dynamic to organization, the subjectivity of people moving the work and relationships inherent in to it. In health the work differs from the others, especially regarding to interpersonal relations and subjectivity of workers and customers. The Intensive Care Unit which operate in different categories of professionals in providing intensive care to patients in critical health conditions, have a unique way of life that makes the professionals attributing meaning of work differently. For the service provided is consistent with both the organization and the principles and values of the professional is necessary for workers to attribute meaning of work. The term meaning refers to the understanding of the rationale to be of the professionals to do their jobs. Given the above, this study aimed to understand the meanings of work for health professionals who work in the ICU of a university hospital in Belo Horizonte. This is a qualitative study conducted in an Intensive Care Unit of a university hospital in Belo Horizonte, Minas Gerais. The subjects were 31 health professionals who worked in direct patient care in the Intensive Care Unit, namely: nurses, nursing technicians, doctors, physiotherapists, speech therapists, nutritionists and psychologists. Data was collected through interviews with semi-structured analyzed by content analysis of Bardin. We analyzed four dimensions of meaning of work: the individual dimension, organizational, social and daily activities. The individual dimension is related to the professional aspects of the subjects that have significant proportions in personal life. The individual values the professional recognition they receive from others and yourself. Also, realize that through the labor he is able to grow personally and professionally in addition to satisfy. The organizational dimension associated with the identification of the professional organization . Thus, it was observed that dimension organizational structure, teamwork, interpersonal relationships and the role of these in the social life of the professional, organizational commitment and recognition of the institution. The dimension to everyday professional work focuses on the act, do work and those resulting from the same, as the pleasure in seeing your work and patient recovery, the perception of the effectiveness and usefulness of it. The social dimension analyzes the social value of work as well as his contribution and inclusion in society. The meaning of work for health professionals working in an ICU in which they act different categorical professionals articulate and reframe the work becomes relevant in the organization of the work process and managerial practices. Moreover, can contribute to design ways to revalue the work and give direction to act in line with organizational goals 
avoiding deviations of behaviors that endanger the assistance beyond the redemption of the human being in its subjective dimension in health practices.

Keyword: Intensive Care Unit, Health Manpower; Nursing; Work. 


\section{LISTA DEFIGURAS}

QUADRO 1 : Dimensões do Trabalho propostas por Hackman e Oldham (1975).

QUADRO 2: Padrões de definição do trabalho determinados por England e Whitley (1990)

FIGURA 1: Dimensões do Sentido do Trabalho

FIGURA 2: Dimensões do Sentido do Trabalho na Saúde. .55

FIGURA 3: Imagem oriunda da Técnica do Gibi 56

FIGURA 4: Imagem oriunda da Técnica do Gibi .73

FIGURA 5: Imagem oriunda da Técnica do Gibi .91

FIGURA 6: Imagem oriunda da Técnica do Gibi. . .96 


\section{LISTADETABELAS}

TABELA 1: Perfil dos sujeitos da pesquisa realizada no CTI de um Hospital Universitário na cidade de Bel Horizonte. 


\section{LISTA DEABREVIATURAS}

COEP - Comitê de Ética em Pesquisa de Seres Humanos

CTI - Centro de Terapia Intensiva

CTT - Composição Técnica do Trabalho

FHEMIG - Fundação Hospitalar do Estado de Minas Gerais

FUNDEP - Fundação de Desenvolvimento e Pesquisa

MOW - Meaning of Work

NEPE - Núcleo de Ensino, Pesquisa e Extensão

SUS - Sistema Único de Saúde

TCLE - Termo de Consentimento Livre e Esclarecido

UFMG - Universidade Federal de Minas Gerais 


\section{SUMÁRIO}

1. INTRODUÇÃ

1.1. Objetivo

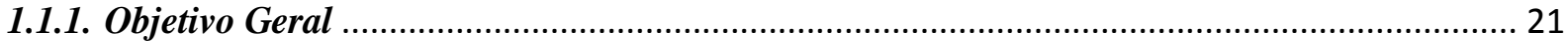

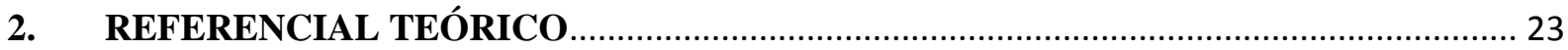

2.1. Relação do homem com o trabalho ao longo do tempo ……............................................. 23

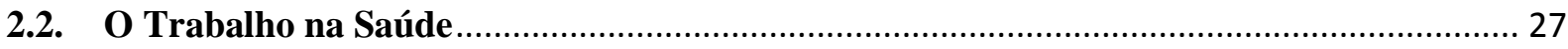

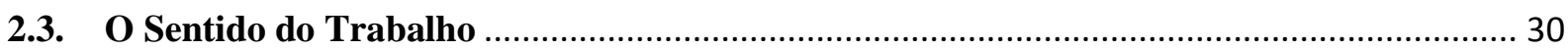

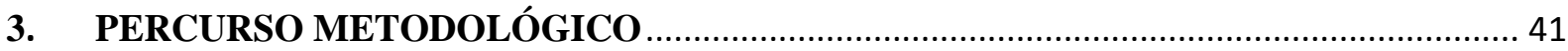

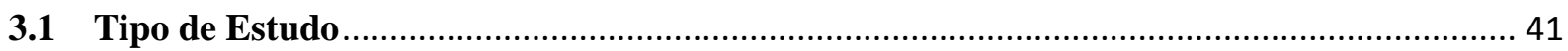

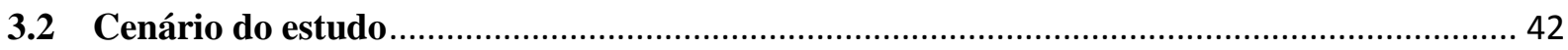

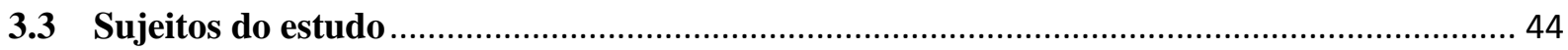

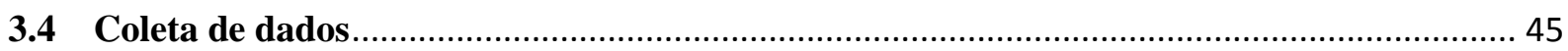

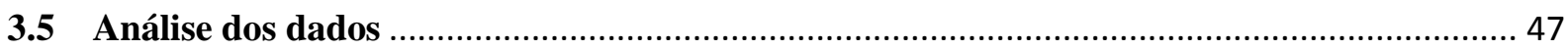

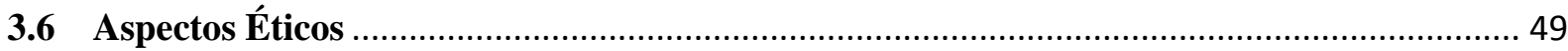

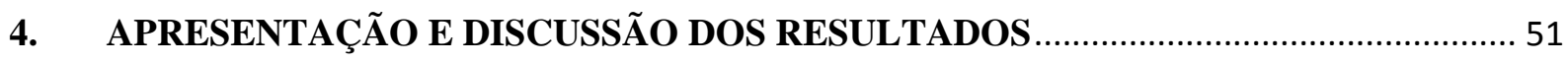

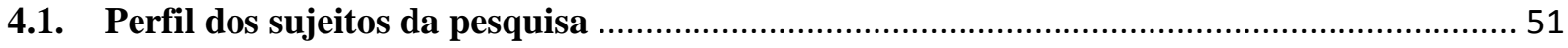

4.2. Perspectiva Analítica do Sentido do trabalho …............................................................. 53

4.2.1. Os Sentidos do Trabalho - A Dimensão Individual .................................................................. 56

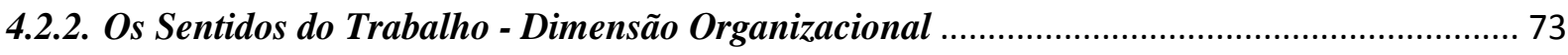

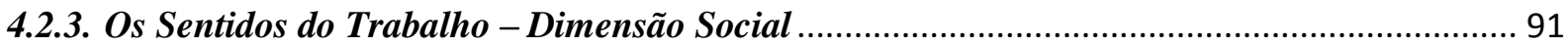

4.2.4. Os Sentidos do Trabalho - Dimensão Fazer Cotidiano ......................................................... 96

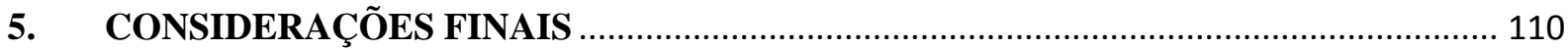

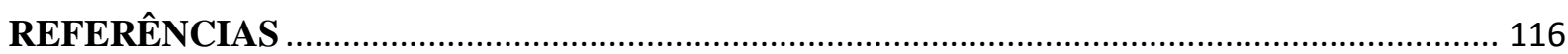

APÊNDICES

ANEXOS 
"O senhor... Mire veja: o mais importante e bonito, do mundo, é isto: que as pessoas não estão sempre iguais, ainda não foram terminadas - mas que elas vão sempre mudando. Afinam ou desafinam. Verdade maior. É o que a vida me ensinou. Isso que me alegra, montão".

(Riobaldo Tatarana em Grande Sertão: Veredas;joão

quimarães Rosa) 


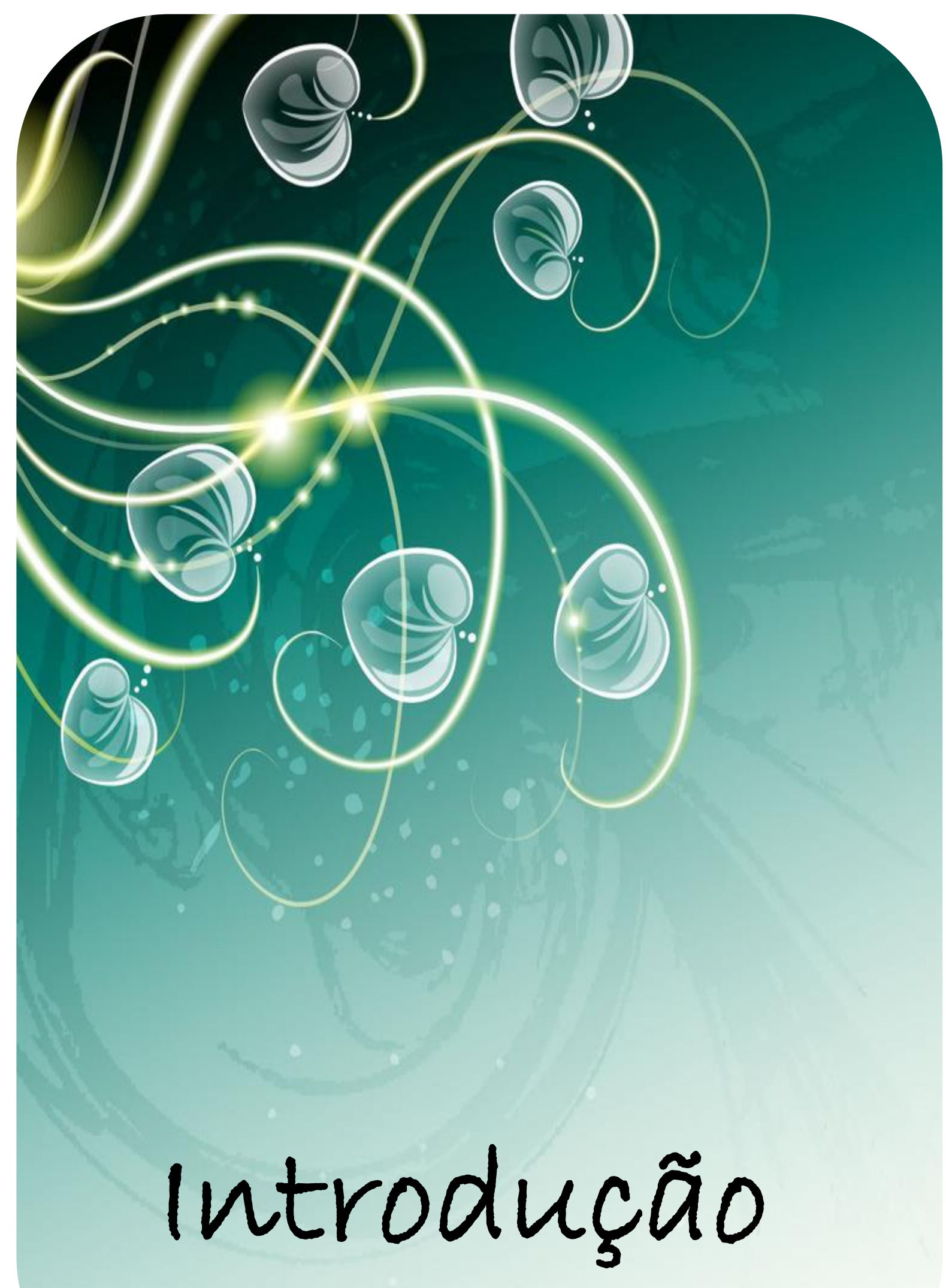




\section{INTRODUÇÃO}

Ao longo da história da humanidade, o trabalho passou por variações em suas formas e concepções, sendo vivenciado e interpretado de diferentes formas pela sociedade e pelo trabalhador. O conceito de trabalho evolui de acordo com o contexto histórico e econômico. Um dos principais autores a abordar a temática foi Karl Marx, que conceitua o trabalho como a capacidade que o homem possui de transformar a natureza para atender à suas necessidades (MARX, 1982). Na década de 1990, Codo (1997) traz contribuições sobre o conceito de trabalho ao pressupor uma relação de dupla transformação entre o homem e a natureza capaz de gerar significados. No século XXI, Silva e Cunha (2002) referem que a atividade produtiva deixa de ser apenas fruto da força física do trabalhador, passando a depender principalmente do conhecimento. Nesse contexto, surgem exigências para que o trabalhador seja um sujeito criativo, crítico e pensante, preparado para se adequar às constantes mudanças.

As organizações se configuram como um dos principais lócus de produção, isto é, onde o trabalho se realiza e é concretizado e, para tal, possuem duas dimensões: a objetiva e a subjetiva. A primeira diz respeito àquilo que está prescrito, normatizado. O trabalho prescrito ainda é hegemônico e está presente na gestão organizacional orientando práticas que, por meio das tarefas, buscam controlar os modos de pensar e agir dos trabalhadores (FERREIRA, 2004). De acordo com Leal (2005), o objetivo principal são as estruturas formais, legalmente prescritas e a conformidade do comportamento individual a tais estruturas. Ferreira (2004) salienta que a dimensão prescrita do trabalho busca uniformizar os trabalhadores a fim de que todos se submetam as mesmas regras e, portanto, se comportem igualmente.

A dimensão subjetiva é determinada pelas relações, afetos e sentimentos. Além disso, não é voltada racionalmente apenas para os resultados, mas para o conteúdo e os meios utilizados para alcança-los. Essa dimensão considera como cada indivíduo percebe a si e o mundo ao seu redor bem como orienta as relações estabelecidas nas organizações e, em função disso, direciona a tomada de decisão dos indivíduos no mundo do trabalho. Dessa forma, Faria (1999) afirma que "o trabalho transforma o homem subjetivamente e transforma a natureza objetivamente", ou seja, a relação não é estática em apenas um âmbito, mas, transita entre as questões concretas e espirituais do homem.

Nesse sentido, Ferreira (2004) ressalta que o bem-estar do trabalhador é encontrado quando existe um equilíbrio entre a o trabalho prescrito e o real. O prescrito deve ser racionalizado nas compatibilidades com as características reais do trabalho cotidiano, assim, 
construindo um novo paradigma na gestão organizacional de caráter antropocêntrico. Pois, são as pessoas que dão vida e dinâmica às organizações uma vez que a subjetividade das pessoas movimenta o trabalho e as suas relações. O trabalho nas organizações de saúde, também é movido pelas dimensões objetivas e subjetivas. O setor saúde se diferencia dos demais, principalmente, no que concerne às relações interpessoais e aos modos de subjetivação dos trabalhadores, pacientes e familiares, destacando-se, portanto, a dimensão subjetiva do trabalho. Segundo Pires (2008, p.159), o "trabalho em saúde é um trabalho essencial para a vida humana e é parte do setor de serviços. É um trabalho da esfera da produção não material, que se completa no ato de sua realização", ou seja, na assistência. Ainda de acordo com a autora, o ato assistencial demanda profissionais com conhecimentos e técnicas específicas para produzir o cuidado às pessoas com necessidades especiais de saúde. Logo, o trabalho em saúde é materializado coletivamente, baseado em saberes e na busca de um propósito comum.

Apesar de a prática em saúde necessitar de conhecimento técnico, prático e específico o objeto de atenção é o ser humano, complexo em sua subjetividade. Portanto, é um trabalho que precisa da racionalidade prescritiva, no que concernem as práticas, as normas, o ambiente e as estruturas necessárias para que ele aconteça. Entretanto, por ser um trabalho feito por indivíduos, direcionado e focado nos sujeitos, a dimensão subjetiva sobressai à objetiva. A subjetividade, para Ramminger e Nardi (2008), refere-se à experiência de ser sujeito, "aquele que é submetido e aquele que realiza a ação" (p. 340). Portanto, como aponta Carvalhaes, Kuriki e Silva (2011), a lógica do trabalho pautada na subjetividade, além de encontrar na organização um lócus para que o profissional desenvolva suas potencialidades como seres humanos, valorizando os recursos humanos envolvidos no trabalho e, também, as características individuais do trabalhador no seu fazer profissional.

No contexto hospitalar, os Centros de Terapia Intensiva (CTI) são unidades especializadas nas quais atuam profissionais de diferentes categorias na prestação de cuidados intensivos à pacientes em estados críticos de saúde. Cabe salientar que se trata de um ambiente no qual as tecnologias de saúde propostas por Mehry (1997) são expressas de forma clara. As tecnologias leves se demonstram nas relações entre os profissionais e deles com os pacientes/familiares, as leve-duras se expressam nos saberes teóricos científicos necessários para o cuidado ao doente crítico e para manusear os equipamentos de alta tecnologia presentes no setor, justificando a presença da tecnologia dura. De acordo com Fischer (1996), além da absorção tecnológica imprescindível, essas unidades complexas possuem um modo singular 
de vida interna que configuram condições favoráveis para a formação e manutenção de padrões culturais específicos.

Algumas especificidades do CTI podem ser elencadas, dentre as quais se destacam: a delimitação do espaço físico propiciando relações mais próximas, tanto entre profissionais quanto entre eles e pacientes/familiares; a utilização exacerbada de tecnologias duras; o predomínio de atividades que demandam articulação e o trabalho em equipe; o convívio com o risco iminente de morte e com situações de sofrimento de pacientes/familiares e; um local onde os problemas éticos e morais são constantes.

Em face aos aspectos mencionados, o CTI é um local cujas relações entre os indivíduos são estreitas podendo resultar em processos de subjetivação bem como possíveis conflitos. Neste aspecto, Gutierrez e Ciampone (2006) salientam que o ambiente do CTI propicia maior tensão entre os profissionais o que pode influenciar negativamente na qualidade da assistência, acarretando prejuízos para o paciente. Ademais, desgastes advindos da carga de trabalho e da tensão do ambiente de trabalho podem afetar a saúde física e mental dos profissionais gerando absenteísmo, rotatividade, falta de atenção e compromisso com as atividades realizadas, desmotivação e descrença com o trabalho. Considerando os desvios de comportamento apontados, Morin (2008) afirma que eles acontecem quando as estratégias defensivas dos profissionais contra a sua visão negativa do trabalho se esgotam e ele passa a não ter sentido para o sujeito.

Em contrapartida, também é um ambiente que oferece aos profissionais subsídios para que cuidem adequadamente dos pacientes, além de possuírem uma equipe multiprofissional com quem compartilham o trabalho e as responsabilidades. Nesse sentido, Safar e Grenvik (2012) expõem que o CTI é um local onde existe monitoramento sofisticado para suporte de vida avançado, bem como conta com sistema que atua em equipe especializada. Além disso, propicia prazer na recuperação da vida do sujeito, corroborando com Almeida e Pires (2007) que asseveram que os profissionais da saúde possuem satisfação com a possibilidade de aliviar a dor, o sofrimento e salvar vidas humanas e, também, por terem a oportunidade de exercer sua profissão de forma completa, do caráter desafiador e dinâmico do trabalho e de ser fonte contínua de aprendizado para o profissional.

Diante do exposto, o CTI é um setor que produz sentimentos ambíguos nos profissionais determinados pelas condições estruturais das organizações, do trabalho em si e pela subjetividade do profissional. Almeida e Pires (2007) reforçam que o trabalho é permeado por normas, isto é, pela dimensão objetiva, mas não basta por si só. O trabalho, 
como uma atividade humana "compreende a subjetividade de cada sujeito e pode ser fonte de sofrimento e de fadiga para uns e de prazer para outros" (p. 621).

Nas organizações em geral, mas enfocando nas de saúde, para que o serviço prestado seja de qualidade e coerente com a os princípios e valores organizacionais e do profissional é necessário que o trabalho tenha sentido para quem o realiza. Morin e Gagné (2009) sustentam que o sentido que a pessoa confere ao trabalho pode ter efeitos positivos sobre a sua saúde psíquica e no seu comprometimento com a organização, pois um trabalho com sentido é percebido como importante pelo profissional, passa a ter valor e faz com que ele envide esforços para concretizá-lo. Portanto, o sentido do trabalho depende da consistência entre a pessoa e o seu trabalho, as expectativas, valores e suas ações no cotidiano de trabalho (MORIN; GAGNÉ, 2009).

Cabe esclarecer que os termos sentidos e significado do trabalho permeiam os trabalhos ora como sinônimos e, outras vezes, são discutidas sua possível diferença. Para fins deste estudo, optou-se por trabalhar com o termo sentidos do trabalho uma vez que o objetivo desta pesquisa não é aprofundar nesta dicotomia. Ademais, o significado neste estudo será considerado parte constituinte da estrutura do sentido do trabalho que se refere à compreensão da razão de ser dos profissionais realizarem o seu trabalho. Dessa forma, este estudo será baseado no sentido do trabalho definido por Morin (2001; 2002; 2004; 2008). Segundo a autora, os sentidos do trabalho são compostos como uma estrutura afetiva formada por três componentes: o significado; a orientação e a coerência.

O significado diz respeito às representações que o sujeito tem da atividade que realiza, assim como o valor que lhe atribui. Já a orientação, refere-se à inclinação do sujeito pelo trabalho, o que ele busca na sua atividade laboral e o que guia suas ações durante a realização delas. E, a coerência é a harmonia ou o equilíbrio que ele espera de sua relação com o trabalho (MORIN, 2004). Sendo então, uma estrutura complexa que agrega componentes da subjetividade do indivíduo, da atividade que ele realiza bem como a congruência entre o trabalho e o trabalhador.

Ainda no que concerne à perspectiva analítica dos sentidos do trabalho, Morin, Tonelli e Pliopas (2007) evidenciam três dimensões a serem consideradas, são elas: a dimensão individual que está ligada à satisfação pessoal (social e profissional), à autonomia e sobrevivência (independência financeira), aprendizado e crescimento, bem como a formação da identidade; a dimensão organizacional se refere à utilidade do trabalho e aos relacionamentos inerentes a ele; e a dimensão social está relacionada à inserção do trabalho na sociedade e sua contribuição para ela. 
As dimensões englobam as estruturas do trabalho e permitem uma análise dos sentidos do trabalho sob uma ótica geral que abarca questões do indivíduo para/com o trabalho, o trabalho dele para a organização e para a sociedade. Ressalta-se que elas coexistem nos sentidos do trabalho e demonstram os aspectos importantes que influenciam o trabalhador no seu fazer profissional.

Nessa perspectiva, Morin (2002) afirma que o trabalho que possui sentido detém algumas características, dentre as quais se destacam: é realizado de forma eficiente e leva a um resultado útil; precisa ser satisfatório por si só, sendo capaz de gerar prazer durante a realização das atividades; permite ao profissional usar do seu talento e potencial com autonomia para resolver problemas; é moralmente aceitável devendo ser realizado de forma socialmente correta, justa e responsável; precisa ser fonte de relações interpessoais satisfatórias passíveis de construir laços de afeição; possibilita segurança associada a um salário digno que garanta a sobrevivência e; é aquele que mantém as pessoas em atividade constante, que ocupa o tempo evitando o ócio (MORIN, 2002).

Portanto, para que o trabalho na área da saúde aconteça de forma coerente torna-se necessário que o profissional encontre sentido em sua realização para que as ações sejam concretizadas de forma segura e a assistência prestada com responsabilidade e qualidade.

Assim, a compreensão dos sentidos do trabalho para profissionais da saúde do CTI, local onde atuam diferentes categoriais de trabalhadores que se articulam e ressignificam o trabalho, torna-se relevante na organização do processo de trabalho e das práticas gerencias. Ademais, estudos dessa natureza podem contribuir para propiciar a revalorização do trabalho conferindo-lhe sentido, de forma que os profissionais ajam em consonância com os objetivos organizacionais, evitando assim, os desvios de comportamentos que comprometem a assistência, bem como contribuir para o resgate do ser humano em sua dimensão subjetiva nas práticas em saúde articulando o trabalho aos objetivos e valores pessoais dos profissionais.

A motivação para esta pesquisa decorre de inquietações pessoais e profissionais da observação da pesquisadora da forma, muitas vezes, descompromissada e sem sentido com que os profissionais da saúde têm conduzido suas práticas profissionais no cotidiano do trabalho.

Tendo em vista as considerações apresentadas buscar-se-á responder à seguinte questão norteadora da investigação: Quais são os sentidos do trabalho para profissionais da saúde que atuam no CTI de um hospital universitário? 


\subsection{Objetivo}

\subsubsection{Objetivo Geral}

Compreender os sentidos do trabalho para profissionais da saúde que atuam no CTI de um Hospital Universitário em Belo Horizonte. 


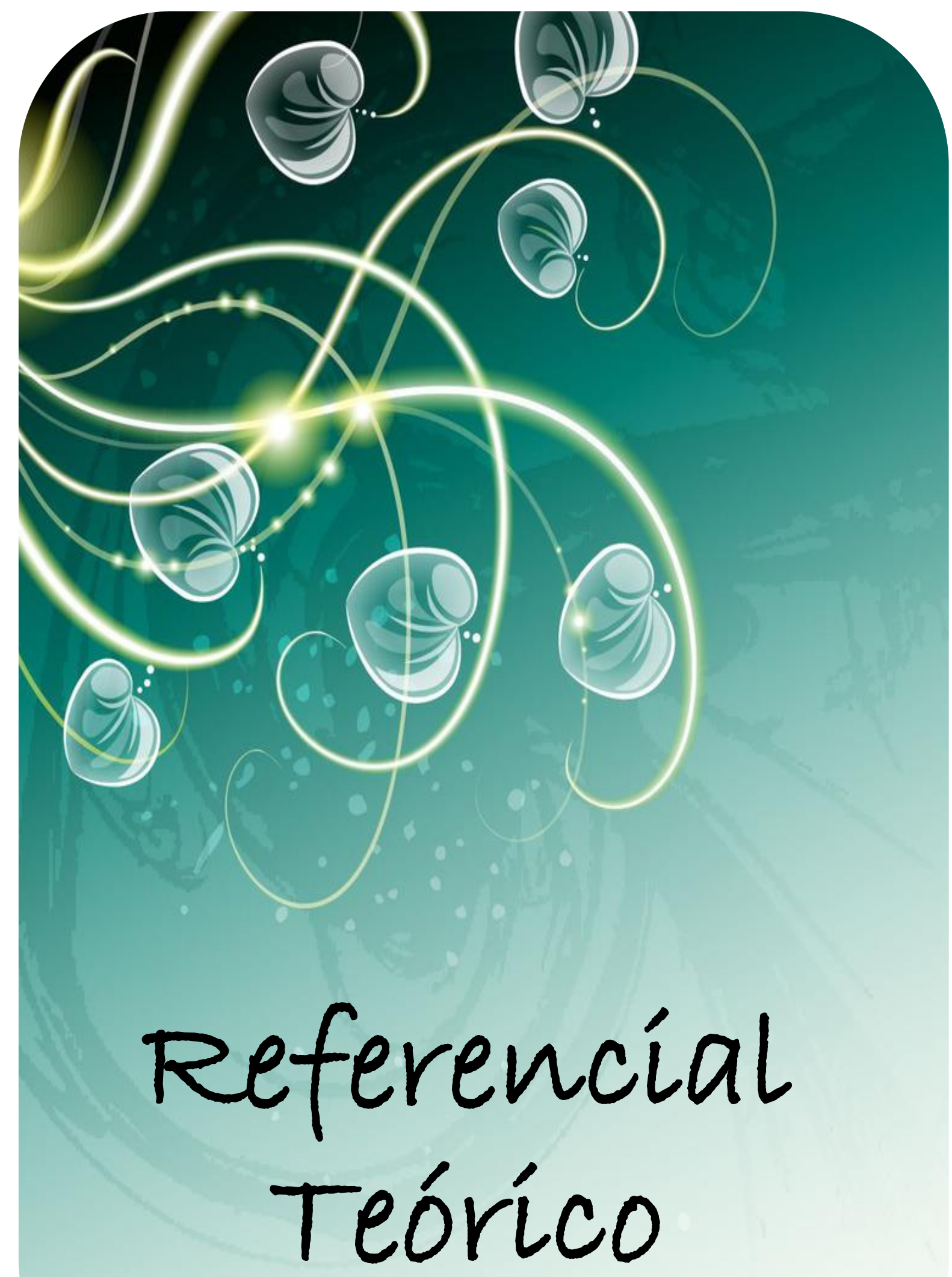




\section{REFERENCIAL TEÓRICO}

\subsection{Relação do homem com o trabalho ao longo do tempo}

A história do homem como um ser capaz de transformar algo em um produto útil para a sociedade ou para si próprio - o trabalho - possui longa evolução. Assim, é importante demonstrar um panorama da relação do homem com o trabalho ao longo do tempo uma vez que essa sofreu diversas transformações e é de extrema importância para entender as relações que o homem atualmente estabelece com o trabalho.

No início do século XIX, as revoluções que assolavam a sociedade fez com que os homens começassem a refletir acerca das questões políticas que norteavam a vida cotidiana da sociedade. Assim, um dos principais filósofos que iniciou a conscientização do sujeito enquanto objeto e, a relação dele com o trabalho, foi Friedrich Hegel (1770-1831). Esse filósofo acreditava, baseado em uma concepção idealista, que em meio a Revolução Francesa e a emergente Revolução Industrial, o trabalho era o que impulsionava o desenvolvimento do ser humano, era nele que homem se produzia (KONDER, 1981). Dessa forma, ele afirmava que por meio do trabalho o homem era capaz de racionalizar, crescer e evoluir em determinada sociedade. Esse filósofo, também defendia a ideia da intencionalidade do trabalho, sendo ele fruto daquilo que o homem almejou (MELO JÚNIOR, 2008). Assim, Friedrich Hegel argumentava suas ideais acerca do trabalho intelectual no qual o homem é capaz de pensar suas atividades antes de realizá-la, defendia assim, o trabalho como um ato de pensar e não apenas como uma ação.

No final do século XIX, a concepção idealista do trabalho foi superada pela visão materialista de Karl Marx (1818-1883). Marx, assim como Hegel, também visualizava o trabalho como a força propulsora do homem, entretanto, ele expôs o trabalho físico e material (KONDER, 1981). Esse pensador defendia o trabalho como a ação do homem materializada no trabalho, como uma forma de executar uma ação. Marx sustentou sua argumentação em meio à sociedade capitalista e, dessa forma, afirmava que o homem possui disposição para o trabalho e este é construído como parte do capital. Assim, Marx afirmava que o trabalho é socialmente necessário, isto é, produz algo que satisfaz a necessidade humana, é útil de alguma forma (MARX, 1982).

Diante do exposto, Marx diferenciou o trabalho em trabalho útil e trabalho abstrato. $\mathrm{O}$ trabalho útil está relacionado à utilidade dele na vida cotidiana que é definida pela matéria prima das mercadorias que lhe dá o valor de uso e, consequentemente, o valor de troca, isto é, 
a produção de lucro em cima do trabalho útil. Dessa forma, o trabalho útil é a manifestação concreta e material do trabalho. Já o trabalho abstrato diz respeito ao esforço do trabalho humano para se alcançar o trabalho útil, ou seja, para produzir valor de uso. É a própria força de trabalho que existe no corpo e na vida de uma pessoa. Entretanto, essa força de trabalho para Marx possui limitações tanto físicas, o que concerne ao esgotamento da força vital necessitando de repouso, quanto às barreiras morais relacionadas à satisfação de necessidades intelectuais e sociais (MARX, 1982). Portanto, é uma visão do trabalho voltada para o ser humano em um contexto no qual o modo de exploração capitalista da força de trabalho reinava desconsiderando o sujeito em sua complexidade sendo apenas como mão de obra.

No século XX, Braverman (1987) retoma o conceito de trabalho baseado na obra de Marx confrontando o trabalho humano versus o trabalho animal. Para esse autor, a espécie humana compartilha com as demais a capacidade de transformar a natureza a seu favor a partir do trabalho. Entretanto, o que se destaca com relação ao trabalho humano é a sua diferença com o trabalho dos outros animais. Em face dessa distinção, Braverman (1987, p. 50) afirma que "o trabalho humano é consciente e proposital, ao passo que o trabalho dos outros animais é instintivo". O ser humano é capaz de planejar antecipadamente os resultados do seu trabalho, isto é, consegue vislumbrar o produto antes mesmo de concebê-lo. Esse mesmo autor expõe que o homem possui o "poder do pensamento conceptual" considerado como a capacidade de pensar inerente ao ser humano. Logo, o trabalho para ele é uma atividade intencional, planejada, orientada pelo intelecto e gera um produto específico. $\mathrm{O}$ trabalho surge então, como misto de pensar e agir. De acordo com Codo (1997) que existe uma relação dúbia entre o homem e a natureza capaz de gerar significados, isto é, essa relação vai além de transformar matéria em algo útil, ela é capaz de produzir significados tanto para o homem quanto para o processo de trabalho.

No século XXI, o conceito de trabalho e a relação do homem com ele são reinterpretados em decorrência da globalização, da nova configuração da sociedade do conhecimento e, ainda, dos avanços tecnológicos. Associando as transformações do século XXI e o conceito de trabalho, Melo Júnior (2008) afirma que o trabalho é um local de intensa relação entre o homem e o meio em que vive e este é, constantemente, modificado, recriado e reinventado. Dessa forma, pode-se inferir que o trabalho deixa de ser considerado apenas como força de trabalho cujo objetivo é produzir um material útil para a sociedade, em um local onde existe troca simbiótica entre aquele que o produz (o homem) e o que foi produzido (produto final) no quais fatores como o relacionamento interpessoal, a cultura, os valores e crenças interferem no processo de produção e nos resultados. 
As transformações no mundo do trabalho no século XXI podem ser analisadas do ponto de vista macro (externas) e micro (internas). Do ponto de vista macro podem ser destacadas questões como a globalização e as inovações tecnológicas, a competitividade e a flexibilização das relações de mercado de trabalho. De acordo com Silva e Cunha (2002) a globalização dos mercados fez emergir a sociedade do conhecimento, transformou o trabalho em uma atividade que valoriza o conhecimento e fez com que o trabalhador se tornasse um ser multifacetado no sentido de ser criativo, crítico, pensante, ter iniciativa e saber agir diante das constantes mudanças pelas quais a sociedade globalizada está sujeita. Além de se adaptarem as inovações tecnológicas que incrementaram o desenvolvimento das máquinas substituindo a mão de obra dos seres humanos, também agilizaram a comunicação e o próprio processo produtivo (SILVA; CUNHA, 2002). Logo, percebe-se que a globalização fez com que os trabalhadores incrementassem conhecimento e características perspicazes para aumentar à produtividade e acompanhar o desenvolvimento mercadológico.

O aumento da competitividade entre as empresas surge neste cenário exigindo cada vez mais do trabalhador enquanto gerador de produtividade e de inovação. Já no contexto micro, tem-se a ruptura no paradigma tradicional do trabalho devido a fatores externos que implicam em novas formas de identificação com o trabalho; investimento no compromisso com a organização o desenvolvimento do trabalho em equipe. O que concerne a identificação do profissional com o trabalho, Pagés et al (1987) refere que o profissional se vincula à organização por meio de laços de identificação materiais/econômicos, afetivos, profissionais, ideológicos e/ou psicológicos de forma que passa a tomar as decisões em função da instituição, ou seja, "veste a camisa da empresa". Assim, a organização possui a capacidade de influenciar o inconsciente do profissional de forma a conectá-lo fortemente à organização.

Os laços de identificação fortalecem o comprometimento que o profissional estabelece com a organização buscando alcançar os além de reforçar o desejo do profissional em manterse como parte dela. O profissional atua de forma congruente aos objetivos organizacionais, ou seja, ele é comprometido com ela de tal forma que volta suas ações em prol das necessidades da organização.

De acordo com Robbins, Judge e Sobral (2010), as organizações modernas passaram por uma reestruturação para competirem no mundo globalizado e, escolheram o trabalho em equipe como forma de utilizar melhor as qualidades profissionais. Isso, porque as equipes são consideradas mais flexíveis, reagem melhor às mudanças, elas participam de forma conjunta à tomada de decisão compartilhando a responsabilidade, além de ser uma forma de democratização das organizações. 
Considerando a evolução da relação do homem com o trabalho desde o século XIX aos dias atuais, é possível classificá-lo de três formas: homo economicus, homo sapiens e homo pragmaticus. Essa classificação foi exposta por Costa (2009) para falar do comportamento dos investidores e também das pessoas comuns diante dos investimentos. Apesar de ser específico para investimentos, é possível utilizar desta classificação para relacionar a forma como os trabalhadores em geral agem diante do contexto econômico e, consequentemente, diante do trabalho.

O termo homo econômicus é abstrato e surgiu no século XIX quando os economistas assumiram que o estudo das ações econômicas e da economia política poderia ser feito abstraindo as dimensões morais, éticas, religiosas, políticas, culturais e psicológicas do comportamento humano. Assim, o homem seria motivado apenas por questões econômicas, preocupando-se em obter o máximo lucro, ele agiria racionalmente em busca da riqueza (COSTA, 2009). Esta visão é justificada pelo capitalismo emergente do século XIX no qual o trabalho era socialmente necessário e a produção do capital prioridade, o sujeito e sua subjetividade não era considerados.

O termo homo sapiens, em contrapartida, considera o homem de forma completa, tal como ele é. Este termo passou a ser usado pelos psicólogos experimentais demonstrando que o comportamento individual, em todas as suas dimensões, viola a racionalidade (COSTA, 2009). Este termo surgiu após homo economicus advindo de questionamentos acerca da fragmentação do homem restando apenas à dimensão econômica e ignorando as demais. Essa evolução do homem demonstra que a subjetividade e os fatores emocionais fazem, de fato, parte do homem como um todo e sua relação com o trabalho e esta, vai além de questões financeiras.

Já o homo pragmaticus está relacionado ao homem voltado para objetivos práticos, àquele que adota ponto de vista, modo de pensar, resolução, isto é, que possui considerações apenas de ordem prática. Este homem sacrifica também, os princípios ideológicos para a consecução de objetivos em curto prazo, ou seja, busca seus objetivos acima de qualquer coisa. É um indivíduo pronto para negócios, voltados para o agir. Do latim pragmaticus derivou para o português pragmático que significa ter experiência, habilidade em negócios, relacionado à ação e ao êxito (COSTA, 2009). Este tipo de homem é encontrado nas grandes empresas nos dias atuais, é aquele imerso na globalização e no capitalismo disposto a tudo para atingir os objetivos da empresa.

A exposição das ideias principais desses pensadores se dá devido à importância das reflexões feitas por eles no que concerne à relação do homem com o trabalho ao longo do 
tempo. Então, após a realização dessa síntese, percebe-se que essa relação é influenciada pelo contexto histórico-econômico por que passa a sociedade e, também, conclui-se que a sociedade atual herdou parte dessas ideias a considerar que o trabalho, atualmente, é fruto tanto da intencionalidade (o pensar) quando da praticidade (o agir). Logo, é relevante conhecer as transformações do homem frente ao trabalho para entendermos as relações que, atualmente, permeiam o mundo do trabalho.

\subsection{O Trabalho na Saúde}

A área da saúde se diferencia das demais, principalmente, no que concerne as relações interpessoais e a subjetividade dos trabalhadores e clientes. É um espaço no qual se articulam diferentes categorias profissionais em prol do paciente, permeado por complexas relações entre profissionais e entre eles e pacientes e familiares, além de ser um lócus de inserção tecnológica e de conhecimento.

O setor saúde é um local de intensas relações e de produção de serviços com os sujeitos e para os sujeitos. As relações são consideradas como parte do processo de trabalho em saúde, abordando a dimensão humana dos atos de saúde, humanizando o trabalhador e também o paciente (MERHY; FRANCO, 1997). Os autores afirmam ainda, que o setor da saúde é o lugar de encontro entre prestadores de serviços e usuários e onde existe intensa atividade de cuidado, sendo considerando uma rede que entrelaça saberes, fazeres e linhas de cuidado. Segundo Pires (2008, p.159), o "trabalho em saúde é um trabalho essencial para a vida humana e é parte do setor de serviços. É um trabalho da esfera da produção não material, que se completa no ato de sua realização”, ou seja, na assistência e nos cuidados em geral ao paciente e aos seus familiares.

A autora refere ainda, que o ato assistencial necessita de profissionais com conhecimentos e técnicas específicas para produzir cuidado para as pessoas com necessidades especiais de saúde. Apesar da prática em saúde necessitar de conhecimento técnico, prático e específico o objeto de atenção é o ser humano, totalmente complexo em sua subjetividade. Assim, Merhy e Franco (1997) apontam que a produção do cuidado acontece envolvendo sujeitos individuais e coletivos previamente acumulados de intencionalidades e impulsionados por suas subjetividades que os conduzem definindo suas ações e as relações produzidas no ato do cuidado. 
Visto que o trabalho em saúde ultrapassa as esferas materiais e objetivas considerada como a dimensão prescrita do trabalho, Merhy (1997) divide as tecnologias de produção em saúde em tecnologia dura, leve-dura e leve. A tecnologia dura está relacionada aos equipamentos e máquinas; a leve-dura com os saberes tecnológicos, clínicos e epidemiológicos e; a leve com os modos relacionais de agir na produção dos atos de saúde. Então, é a coexistência das tecnologias em saúde nas organizações de saúde que regem o cuidado e, para que o serviço seja prestado com qualidade, as tecnologias precisam ser utilizadas em iguais proporções.

Em contrapartida, Merhy e Franco (1997) apontam que as tecnologias duras prevalecem atualmente no processo de produção do cuidado, considerando o modelo médico hegemônico ainda predominante. As tecnologias duras assolam a produção do cuidado se sobressaindo às tecnologias leves que propõem centralidade no usuário e suas necessidades. Isso acontece devido aos interesses financeiros e das coorporativas que lucram com a venda das tecnologias duras em saúde. Esse modelo que rege o trabalho na saúde se estrutura de forma contrária à autonomia dos sujeitos uma vez que são barreiras de contenção da subjetividade. Portanto, se configura como a soberania das estruturas sobre o sujeito, das tecnologias duras sobre as leves.

As tecnologias de produção em saúde possuem importância no trabalho em saúde, entretanto, a tecnologia leve é mais complexa uma vez que está relacionada com a subjetividade das relações em saúde. De acordo com Merhy (1997), adotar um modelo voltado para as necessidades subjetivas dos usuários deve ser centrado nas tecnologias leveduras e, principalmente, nas leves. As tecnologias leves se dão no acolhimento, no vínculo estabelecido entre pacientes e profissionais, na autonomia dos processos de trabalho e no compartilhamento do mesmo entre os profissionais com o enfoque para a qualidade do cuidado ao paciente (MERHY, 1997). Portanto, as tecnologias leves de produção em saúde enfocam o ser humano (usuários e profissionais) e suas necessidades.

A produção em saúde se realiza em ato, seja no exato momento em que se presta o cuidado ao paciente como também, na interação com diferentes tecnologias, instrumentos, materiais e máquinas que foram produzidas em um trabalho anterior àquele do cuidado. Nesta perspectiva, Merhy e Franco (2003) referem que o processo do cuidado em saúde depende da forma como o trabalho vivo e o morto se comporta tendenciado para as relações ou para as tecnologias instrumentais. Com relação ao trabalho vivo, o profissional realiza o trabalho juntamente ao paciente, em ato e, o trabalho morto é aquele anterior ao trabalho vivo realizado para a produção de insumos e tecnologias (trabalho morto). Quando houver 
predomínio do trabalho morto significa que o cuidado será baseado na utilização das tecnologias duras e, quando prevalecer o trabalho vivo em ato, a produção do cuidado será baseada em tecnologias leves de cuidado. No primeiro caso, a proposta terapêutica será fundamentada no modelo prescritivo e instrumental do cuidado no qual o paciente tem pouca ou nenhuma autonomia sobre o processo do cuidado, enquanto no segundo caso, o paciente é considerando um sujeito condicionado pela construção social, composto por suas relações sociais e familiares, imerso de uma subjetividade e, cuja proposta deve estimular a autonomia do paciente para que ele seja sujeito ativo no processo do cuidado (MERHY; FRANCO, 2003).

O modelo de produção da saúde ideal é aquele capaz de atender as reais necessidades do paciente. Dessa forma, Merhy e Franco (2003) apontam que os serviços de saúde devem prover todos os recursos tecnológicos necessário para o cuidado, mesmo que isso implique em altos insumos tecnológicos, mas também utilizar do trabalho vivo em ato garantindo a integralidade da atenção à saúde considerando a autonomia do paciente. Logo, um recurso não deve sobrepor o outro, mas coexistirem no fazer profissional, não sendo envidados esforços no que condiz ao uso de tecnologias duras e a potencialidade das tecnologias leves.

Considerando ainda a produção de um modelo ideal de produção em saúde, o trabalho deve ser realizado coletivamente de forma que um profissional, independente de sua formação, dependa do trabalho do outro para dar continuidade ao cuidado integral. O campo da saúde envolve a interação entre pessoas, tanto entre os profissionais quanto entre os profissionais e pacientes, tornando-se um espaço no qual os conflitos são constantes uma vez que existem interesses diversos, tais como: os pessoais e profissionais dos funcionários, os dos pacientes e familiares além dos interesses financeiros das organizações e das corporações. Nesse sentido, Merhy e Franco (2003) afirmam que o local no qual se produz saúde é um lugar de constante tensão uma vez que diversos interesses e valores dos sujeitos se confrontam além das vontades individuais dos próprios trabalhadores, dos usuários, do governo e dos mercados.

Entretanto, o interesse que deve prevalecer é o cuidado ao paciente de forma que os profissionais voltem suas ações em prol deles para que sejam assistidos da melhor forma possível. Além disso, os profissionais precisam valorizar e estimular os relacionamentos interpessoais e articular seus valores e princípios com o seu trabalho para que realize o cuidado de forma coerente com o objetivo do setor saúde. 


\subsection{O Sentido do Trabalho}

O trabalho é considerado central na vida das pessoas, como uma condição existencial. No contexto das organizações, são as pessoas que movimentas as relações e a produção de serviços e, para que as atividades aconteçam em consonância com os princípios e valores organizacionais e profissionais é necessário que os trabalhadores atribuam sentidos ao trabalho que realizam.

A palavra "sentido" no dicionário da língua portuguesa nos remete a razão de ser, pensamento, consciência; filosoficamente é conhecer de um modo imediato e intuitivo, senso. E a palavra "significado" remete ao conceito ou à noção de algo (FERREIRA, 1995). Assim, percebe-se que o sentido possui uma representatividade mais ampla do que significado, sendo algo mais complexo e até mesmo engloba o conceito da palavra significado.

Observou-se na literatura que, apesar dos autores na maioria das vezes, optarem por um dos dois termos isso não significa que eles estão diferenciando-os, visto que eles utilizam o mesmo referencial teórico para tratar tanto do significado quanto dos sentidos do trabalho. Como exemplo, as pesquisas desenvolvidas nesta temática por Estelle Morin (2001; 2002; 2004; 2008; 2009) que considera o termo "sentidos do trabalho" são fortemente influenciadas pelo grupo Meaning of Work MOW (1987) que trabalha com o termo significado do trabalho.

Neste aspecto, Tolfo e Piccinini (2007) conceituam sentido e significado de forma diferente. Para as autoras, o significado é algo construído coletivamente e em um determinado contexto histórico, cultural e social e; o sentido é construído pessoalmente em função daquilo que o indivíduo apreendeu coletivamente no cotidiano. Entretanto, as autoras apontam que os resultados das pesquisas dos principais autores que estudam essa temática, independente do termo que utilizam, contribuem para a discussão acerca da importância do trabalho na vida das pessoas. Portanto, a escolha e a utilização do termo não são centrais na discussão acerca deste tema. Ademais, o termo sentido ou significado sofrem transformações e são construídos a partir de uma relação dialética com a realidade. Assim, Tolfo e Piccinini (2007), referem que os estudos que envolvem tanto o sentido quando o significado deve ser estudado de forma multidisciplinar visto a natureza e dinâmica do trabalho:

O fenômeno de atribuir sentidos e significados ao trabalho precisa ser estudado em uma perspectiva multidisciplinar, pois se trata de um construto psicológico multidimensional e dinâmico, e que resulta da interação entre variáveis pessoais e sociais relacionadas ao trabalho (TOLFO; PICCININI, 2007 p.45). 
Diante do exposto, este estudo não irá se ater em tal dicotomia ou justificá-la optandose assim, por trabalhar com o termo "sentido" considerando-o como sinônimo de "significado" uma vez que os dois termos referem-se à compreensão da razão de ser dos profissionais ao realizarem seu trabalho.

O trabalho é significante na vida pessoal dos trabalhadores. Ele influencia na qualidade de vida uma vez que é multidimensional, assim sendo, o trabalho e a vida se sobrepõem (TOLFO; PICCININI, 2001). É necessário que o profissional encontre sentido tanto exterior quanto interiormente no trabalho para que ele realize suas atividades produtivamente. Nesse sentido, Antunes (2011) afirma que é incompatível ter uma vida sem sentido no trabalho e com sentido na vida pessoal. Esses caminham juntos e precisam estar interconectados.

Os estudos de Hackman e Oldham (1975) foram pioneiros nesta temática. Eles consideram que o trabalho possui sentidos quando o profissional percebe a importância, a utilidade e a legitimidade do trabalho que realiza, estando intimamente conectado com a qualidade de vida e com as diferenças individuais o que influencia na motivação, satisfação e produtividade do profissional.

Esses autores apresentaram o instrumento denominado de Job Diagnostic Survey (Pesquisa de Diagnóstico do Trabalho) para mensurar a qualidade de vida no trabalho. Eles defendem que resultados positivos no trabalho, tais como alta motivação interna no trabalho, satisfação elevada no trabalho, desempenho de alta qualidade, baixo absenteísmo e rotatividade, são obtidos quando três "estados psicológicos críticos" estão determinados no profissional. Essas três condições subjetivas do trabalhador são: significância da experiência do trabalho, responsabilidade percebida pelos resultados do seu trabalho e conhecimento dos resultados do trabalho. Os "estados psicológicos críticos" são processos individuais não influenciados pela gestão do trabalho, mas sim, pelas cinco "dimensões essenciais do trabalho" que são características que um trabalho precisa ter para que possua sentido, dentre as quais: variedade de habilidades, identidade da tarefa, significado da tarefa, autonomia e feedback. Portanto, as características subjetivas do profissional e as do trabalho são mediadas pela necessidade de crescimento pessoal revelando assim, o potencial motivador (HACKMAN; OLDHAM, 1975).

As cinco "dimensões essenciais do trabalho" são características determinantes de um trabalho que faz com que os profissionais sintam-se motivados em exercer suas atividades uma vez que estão em consonância com as suas ambições, valores, objetivos de vida e necessidades de atuação. Logo, o trabalho passa a ter sentido quando atende certos princípios 
e valores dos indivíduos o que, consequentemente, faz com que esse profissional atenda às demandas e necessidades organizacionais. Com relação a essas dimensões, Hackman e Oldham (1975) caracterizam cinco principais dimensões e outras duas dimensões complementares e as conceitua conforme o Quadro 1 abaixo:

\section{Quadro 1 - Dimensões do Trabalho propostas por Hackman e Oldham (1975), Belo Horizonte, 2013.}

(continua)

\begin{tabular}{|c|c|}
\hline Dimensões do Trabalho & Conceito \\
\hline Variedade de habilidade & $\begin{array}{l}\text { O trabalho precisa requerer do profissional uma } \\
\text { variedade de atividades fazendo com que ele utilize } \\
\text { diversas habilidades e talentos; }\end{array}$ \\
\hline Identidade da tarefa & $\begin{array}{l}\text { O profissional precisa se reconhecer nos resultados do } \\
\text { trabalho além da sua contribuição, isto é, ele precisa } \\
\text { visualizar o trabalho do início ao fim; }\end{array}$ \\
\hline Significado da tarefa & $\begin{array}{l}\text { O trabalho precisar exercer impacto substancial na } \\
\text { própria vida do trabalhador ou no trabalho de outras } \\
\text { pessoas, seja imediatamente na organização ou fora } \\
\text { dela; }\end{array}$ \\
\hline Autonomia & $\begin{array}{l}\text { O profissional deve ter liberdade substancial, } \\
\text { independência e descrição na realização do seu trabalho } \\
\text { e na determinação dos procedimentos a serem utilizados } \\
\text { em sua realização; }\end{array}$ \\
\hline Feedback do trabalho em si & $\begin{array}{l}\text { O profissional precisa ter retorno dos resultados do seu } \\
\text { trabalho obtendo informação direta e clara sobre a } \\
\text { eficácia do seu desempenho; }\end{array}$ \\
\hline
\end{tabular}


(conclusão)

\begin{tabular}{|l|l|}
\hline Dimensões Complementares & Conceito \\
\hline O feedback dos agentes & $\begin{array}{l}\text { O profissional recebe informações claras sobre seu } \\
\text { desempenho pelos supervisores ou colegas de trabalho. } \\
\text { Esta é uma complementação da dimensão do feedback; }\end{array}$ \\
\hline Lidar com os outros & $\begin{array}{l}\text { O trabalho requer do empregado que ele estabeleça } \\
\text { estreita colaboração com outras pessoas na realização } \\
\text { das atividades (incluindo relações com outros membros } \\
\text { da organização e com clientes). }\end{array}$ \\
\hline
\end{tabular}

Fonte: Elaborada para fins deste estudo baseado em Hackman e Oldham (1975)

Considerando as dimensões do trabalho que são essenciais para que um trabalho tenha sentido, Hackman e Oldham (1975) afirmam que o potencial motivador que as dimensões podem causar não afeta a todos os profissionais da mesma forma. As dimensões produzem efeito em pessoas que possuem sentimento de autovalorização e desejo de crescimento.

Percebe-se que esses autores definiram cinco principais características que estimulam o profissional a realizarem suas atividades, isto é, dimensões do trabalho que fazem com que os profissionais encontrem sentido no trabalho. Ademais, essas características surtem efeito quando o profissional possui vontade de crescer e ser um sujeito ativo em sua atividade profissional, emergindo assim, o tipo de profissional que as empresas exigem atualmente, mesmo se tratando de um estudo feito na década de 1970.

Posteriormente, no início da década de 1980, a equipe de investigação internacional Meaning of Work (MOW) passou a se destacar na condução de pesquisas na temática do sentido do trabalho em vários países, entre eles: Bélgica, Inglaterra, Alemanha, Israel, Japão, Holanda, Estados Unidos e ex-Iugoslávia. De acordo com Goulart (2009), essa equipe partiu do pressuposto de que o significado do trabalho exerce influencia na forma como o profissional vivencia suas atividades no trabalho e possui interferência histórica/filosófica na vida dos indivíduos. O trabalho para MOW (1987) se apresenta de forma central na vida das pessoas indo além da dimensão econômica, e integra três eixos principais: a centralidade do trabalho, as normas sociais sobre o trabalho e as metas e os resultados do trabalho.

Considerando os três eixos principais do trabalho como norteador do significado do trabalho para o indivíduo, Goulart (2009) em seu estudo sintetiza esses eixos baseado nos trabalhos do grupo MOW. De acordo com Goulart (2009), a centralidade do trabalho refere-se à importância que o profissional atribui a sua atividade bem como a condição existencial que 
lhe é conferida, demonstrando o significado do trabalho que o indivíduo adquire ao longo da sua experiência. Já o segundo eixo, as normas sociais sobre o trabalho, refere-se aos direitos e deveres associados ao trabalho relacionando-os aos valores que o profissional atribui à sua atividade. O direito é aquilo que o funcionário deve exigir da organização que presta serviço no que concerne às condições e características do trabalho, e o dever são as obrigações que ele deve cumprir tanto com a organização quanto com a sociedade. Quanto ao terceiro eixo, as metas e os resultados laborais, as metas indicam as características das atividades desenvolvidas e os resultados referem-se ao que o funcionário busca no trabalho (GOULART, 2009). Esses eixos representam a razão de ser das atividades desenvolvidas pelos profissionais no trabalho além de demonstrar o cerne do valor do trabalho atribuído por eles.

O grupo MOW (1987) definiu, ainda, características generalizáveis que constituem o trabalho nas regiões em que foi realizada. Entretanto, destacaram que as características podem variar dependendo do tipo de profissão, cultura, e os próprios conceitos individuais. Para definir os padrões de trabalho, MOW (1987) desenvolveu uma série de questionários, ainda hoje utilizados, e chegou-se em seis padrões classificados de A a F, como pode ser observado no Quadro 2.

\section{QUADRO 2 - Padrões de definição do trabalho determinados por England e Whitley $(\mathbf{1 9 9 0})^{1}$,}

(continua)

\begin{tabular}{|c|c|c|}
\hline Padrão A & Padrão B & Padrão C \\
\hline $\begin{array}{l}\text { - Acrescenta valor a qualquer } \\
\text { coisa } \\
\text { - Você deve prestar conta } \\
\text { disso } \\
\text { - Faz parte das suas tarefas } \\
\text { - Você recebe dinheiro para } \\
\text { fazer isso }\end{array}$ & $\begin{array}{l}\text { - Realizando isto, você tem } \\
\text { sentimento de vinculação } \\
\text { - Você recebe dinheiro para } \\
\text { realizar isto } \\
\text { - Você faz para contribuir à } \\
\text { sociedade } \\
\text { - Faz parte de suas tarefas }\end{array}$ & $\begin{array}{l}\text { - Outros se beneficiam disto } \\
\text { - Você recebe dinheiro para } \\
\text { realizar isto } \\
\text { - Você faz para contribuir à } \\
\text { sociedade } \\
\text { - Acrescenta valor a } \\
\text { qualquer coisa } \\
\text { - É fisicamente exigente }\end{array}$ \\
\hline
\end{tabular}

${ }^{1}$ Esses autores fazem parte da equipe Meaning of Work (MOW). ENGLAND, G.W; WHITELEY, W.T. Crossnational meanings of working. In: BRIEF, A.P; NORD, W.R. Meanings of occupational work. Toronto: Lexington Book, 1990, p.65-106. 
(conclusão)

\begin{tabular}{|l|l|l|}
\hline Padrão D & Padrão E \\
\hline $\begin{array}{l}\text { - Você recebe dinheiro para } \\
\text { fazer isto }\end{array}$ & - É mentalmente exigente \\
- Faz parte de suas tarefas & - É fisicamente exigente \\
- Você realiza em um local de & - Você recebe dinheiro para \\
trabalho & fazer isto \\
- Você deve fazer isso & - Faz parte de suas tarefas \\
- Alguém lhe diz o que fazer & - Isto não está agradando \\
- Não é agradável & $\begin{array}{l}\text { Padrão F } \\
\text { horário }\end{array}$ \\
\hline & $\begin{array}{l}\text { - Você realiza em um local } \\
\text { de trabalho } \\
\text { - Você recebe dinheiro para } \\
\text { fazer isto } \\
\text { Faz parte de suas tarefas }\end{array}$ \\
\hline
\end{tabular}

Fonte: Morin (2001)

Percebe-se que em todos os padrões o salário aparece como um elemento importante, mas, não central. De acordo com Morin (2001), os padrões A, B e C correspondem a uma visão positiva do trabalho e valorizam o caráter social dele, $\mathrm{D}$ e E correspondem às visões negativas do trabalho uma vez que é apresentado como uma obrigação do indivíduo para sobreviver. Já o padrão F apresenta uma concepção neutra do trabalho, na qual o indivíduo não possui uma posição determinada.

A partir desses padrões, foi possível identificar o significado que os sujeitos atribuem ao trabalho. Nesse aspecto, Tolfo e Piccinini (2007) referem que a equipe MOW passou então, a conceituar o significado do trabalho como "um construto psicológico multidimensional e dinâmico, formado da interação entre variáveis pessoais e ambientais e influenciado pelas mudanças no indivíduo, ao seu redor ou no trabalho" (TOLFO; PICCININI 2007, p. 39).

Portanto, para MOW (1987) o significado do trabalho é um constructo a partir de uma realidade social em determinado contexto histórico influenciado por variáveis indivíduas e sociais. Ademais afirmam que o significado influencia as condutas dos profissionais em suas atividades laborais e, principalmente, na produtividade, pois o significado do trabalho provoca as representações e crenças dos indivíduos acerca do que é aceito ou não no ambiente de trabalho. 
Para fins desse estudo, optou-se por trabalhar com o sentido do trabalho definido por Morin (2001, 2002, 2004, 2008). Para Morin (2001), a realização de estudos nesta temática se torna importante uma vez que os problemas de desempenho podem ser solucionados a partir desta perspectiva. Pois, a organização do trabalho deve conduzir o comportamento do profissional de forma que ele desenvolva suas atividades de forma positiva tanto para organização quanto para ele, assim Morin (2001), afirma:

\footnotetext{
A organização do trabalho deve oferecer aos trabalhadores a possibilidade de realizar algo que tenha sentido, de praticar e desenvolver suas competências, de exercer seus julgamentos e seu livre arbítrio, de conhecer a evolução dos seus desempenhos e de se ajustar (MORIN, 2001 p. 9).
}

Percebe-se o importante papel da organização do trabalho na instituição uma vez que ela é a responsável por grande parte do sentido conferido ao trabalho fazendo com que os profissionais adequem suas condutas às necessidades da instituição. Logo, o comprometimento organizacional depende do grau de correspondência entre as características das pessoas e as propriedades das atividades desempenhadas (MORIN, 2002). Nesse sentido, Morin e Tonelli (2007) afirmam que as características do trabalho devem sem coerentes com os motivos que estimulam os profissionais ao fazer profissional.

Morin (2001) em seu estudo acerca dos sentidos do trabalho, afirmou que para um trabalho possuir sentido ele deve ser feito de maneira eficiente, conduzir a alguma coisa específica, beneficiar outras pessoas, atender aos objetivos pessoais do trabalhador e permitir constante aprendizado (MORIN, 2001).

Entretanto, não somente das dimensões objetivas da organização que o sentido do trabalho é construído. Considerando que o trabalho é fundamental na vida do indivíduo moderno, para compreender essa relação e, a atribuição de sentido conferida a ele é necessário conjecturar variáveis, como afirma Dourado et al (2010), desde estruturais até fatores psicológicos. Portanto, os fatores psicológicos também fazem parte da construção de sentidos. Segundo Morin (2004), o sentido do trabalho é conceituado como uma estrutura afetiva formada por três componentes, sendo eles: o significado, a coerência e a orientação. $\mathrm{O}$ significado diz respeito às representações que o sujeito possui da atividade que realiza, assim como o valor que the atribui e a centralidade dela na vida. Já a orientação, refere-se à inclinação do sujeito pelo trabalho, o que ele busca na atividade e o que guia suas ações. . E a coerência é a harmonia ou o equilíbrio que o sujeito possui com o seu trabalho (MORIN, 2004). 
O sentido do trabalho está relacionado com o compromisso que o profissional possui com a organização, isto é, a forma como os profissionais conduzem suas atividades e atitudes em consonância com os objetivos organizacionais e também, com seus objetivos e perspectivas de vida, valores e princípios. Nessa perspectiva e levando em consideração os componentes do sentido do trabalho, Morin (2001) afirma que o processo de trabalho faz com que o profissional encontre e forme constantemente sua identidade. Portanto, o trabalho precisa ter sentido para que o profissional se reconheça em ato e seja capaz de crescer como pessoa e profissional.

Nesse mesmo aspecto, Morin, Tonelli e Pliopas (2007) destacam que na perspectiva analítica do sentido do trabalho três dimensões devem ser consideradas, como esquematizado na Figura 1:

\section{Figura 1 - Dimensões do Sentido do Trabalho, Belo Horizonte, 2013}

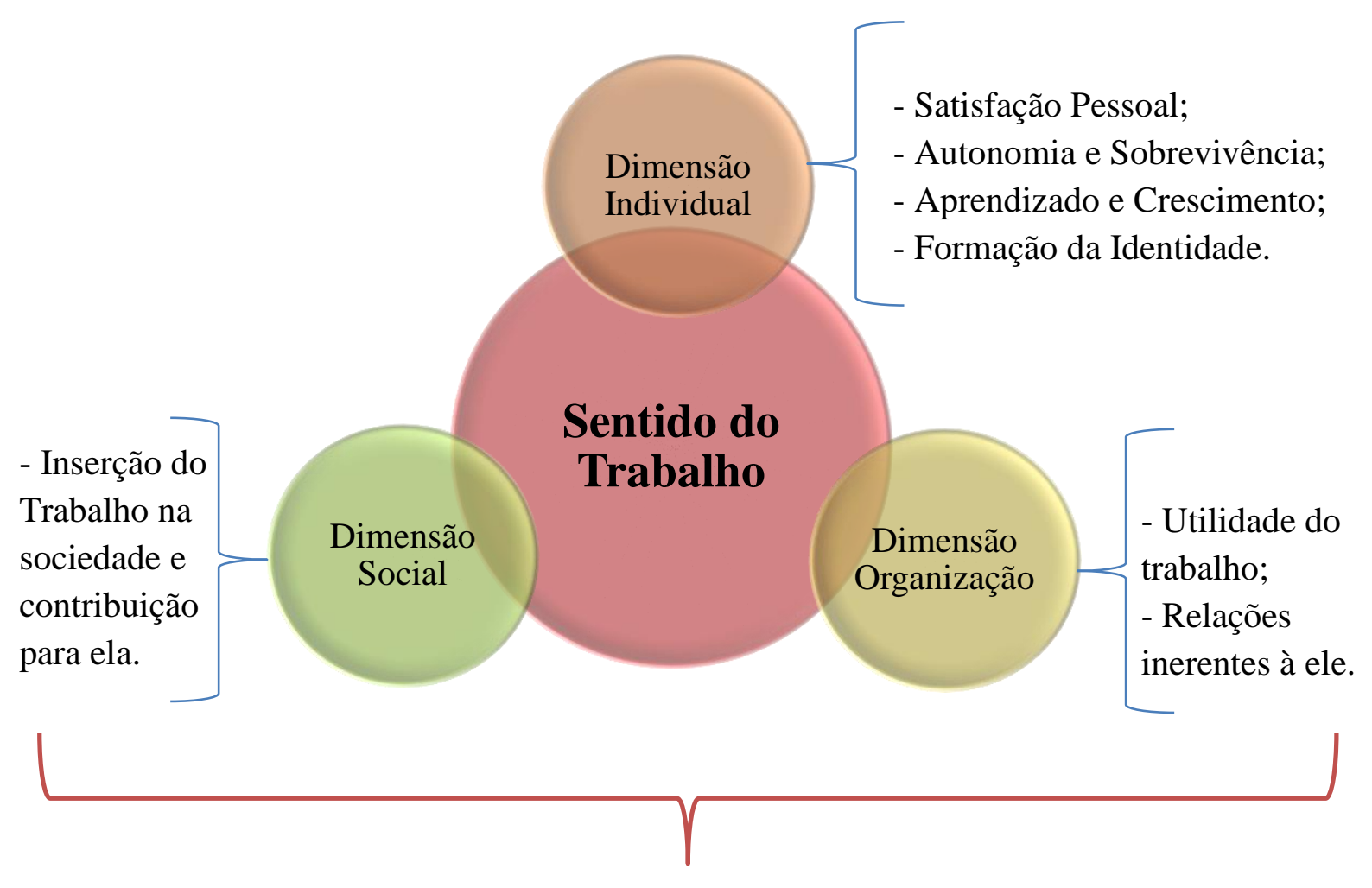

Coexistem no sentido do trabalho

Fonte: Elaborada para fins deste estudo baseada no estudo de Morin, Tonelli e Pliopas (2007)

A dimensão individual está associada tanto aos aspectos sociais e particulares do indivíduo como sua vida profissional. A satisfação pessoal está relacionada com o prazer do 
profissional em exercer suas atividades, isto é, ele gosta do que faz e percebe sua contribuição para o serviço. A autonomia e sobrevivência são referentes à remuneração como fruto do trabalho e as possibilidades de independência que proporciona. Entretanto, a questão salarial frequentemente é acompanhada de outro elemento, não sendo considerada como o ponto principal. $\mathrm{O}$ aprendizado e crescimento são relacionados, pois os profissionais se preocupam com uma possível estagnação em suas profissões e a aquisição de conhecimento proporciona a oportunidade de crescer hierarquicamente além de aprimorar suas competências para realizarem o trabalho com qualidade. A identidade se refere ao orgulho do profissional quanto ao trabalho realizado, à identificação com ele e também a constante formação da identidade pessoal e profissional (MORIN; TONELLI; PLIOPAS 2007).

A dimensão organizacional está associada a utilidade do profissional para concretizar os objetivos organizacionais e as relações inerentes ao ambiente de trabalho. A utilidade, o profissional percebe por meio do produto gerado pelo trabalho o seu propósito. Para tal, o profissional precisa ter a visão total do processo que e ele participa dele do inicio ao fim. Os relacionamentos estão associados à interação do profissional com outras pessoas, ao trabalho em equipe e ao reconhecimento da instituição pelo seu trabalho (MORIN; TONELLI; PLIOPAS 2007).

A dimensão social está relacionada à inserção do profissional na sociedade e a contribuição do trabalho para a mesma. O trabalho faz com que o indivíduo se sinta pertencente à sociedade, pois trabalhar é um papel que o ser humano deve desenvolver dentro de um grupo social. Além disso, deve contribuir de alguma forma para a sociedade, precisa ser considerado moralmente ético e aceitável pela sociedade (MORIN; TONELLI; PLIOPAS 2007).

Morin (2002) identifica seis características que concede sentidos ao trabalho, são elas: o trabalho é feito de forma eficiente e leva a um resultado útil; precisa ser satisfatório por si só sendo capaz de gerar prazer durante a realização das atividades; permite ao profissional usar do seu talento e potencial com autonomia para resolver problemas; é moralmente aceitável devendo ser realizado de forma socialmente correta, justa e responsável; precisa ser fonte de relações interpessoais satisfatórias sendo passível de construir laços de afeição; possibilita segurança pois, está associado a um salário digno que garanta a sobrevivência e; é aquele que mantém as pessoas em atividade constante e ocupa o tempo evitando o ócio.

Para que o trabalho contemple as dimensões do sentido do trabalho, é importante que os profissionais conheçam os objetivos organizacionais de forma clara e que tenham significado para que sejam valorizados pelo trabalhador. Assim, suas condutas refletirão um 
desempenho positivo para a organização fazendo com que o profissional possua prazer e se realize no trabalho.

Estudos voltados para o sentido do trabalho foram desenvolvidos por psicólogos, sociólogos, administradores e professores da comunicação social em busca do sentido/significado do trabalho (TOLFO; PICCININI, 2007). Entretanto, pouco se estudou sobre essa temática na área da saúde sendo importante se aprofundar considerando as contribuições que pode proporcionar. Além disso, os estudos comumente realizados utilizam de questionários estruturados para definir sentido do trabalho de acordo com um padrão préestabelecido. Neste estudo, optou por trabalhar com o discurso do sujeito por considera-lo representação da prática por meio da linguagem. Portanto, captando a subjetividade e a individualidade do sujeito inserido em determinado contexto e realidade. 


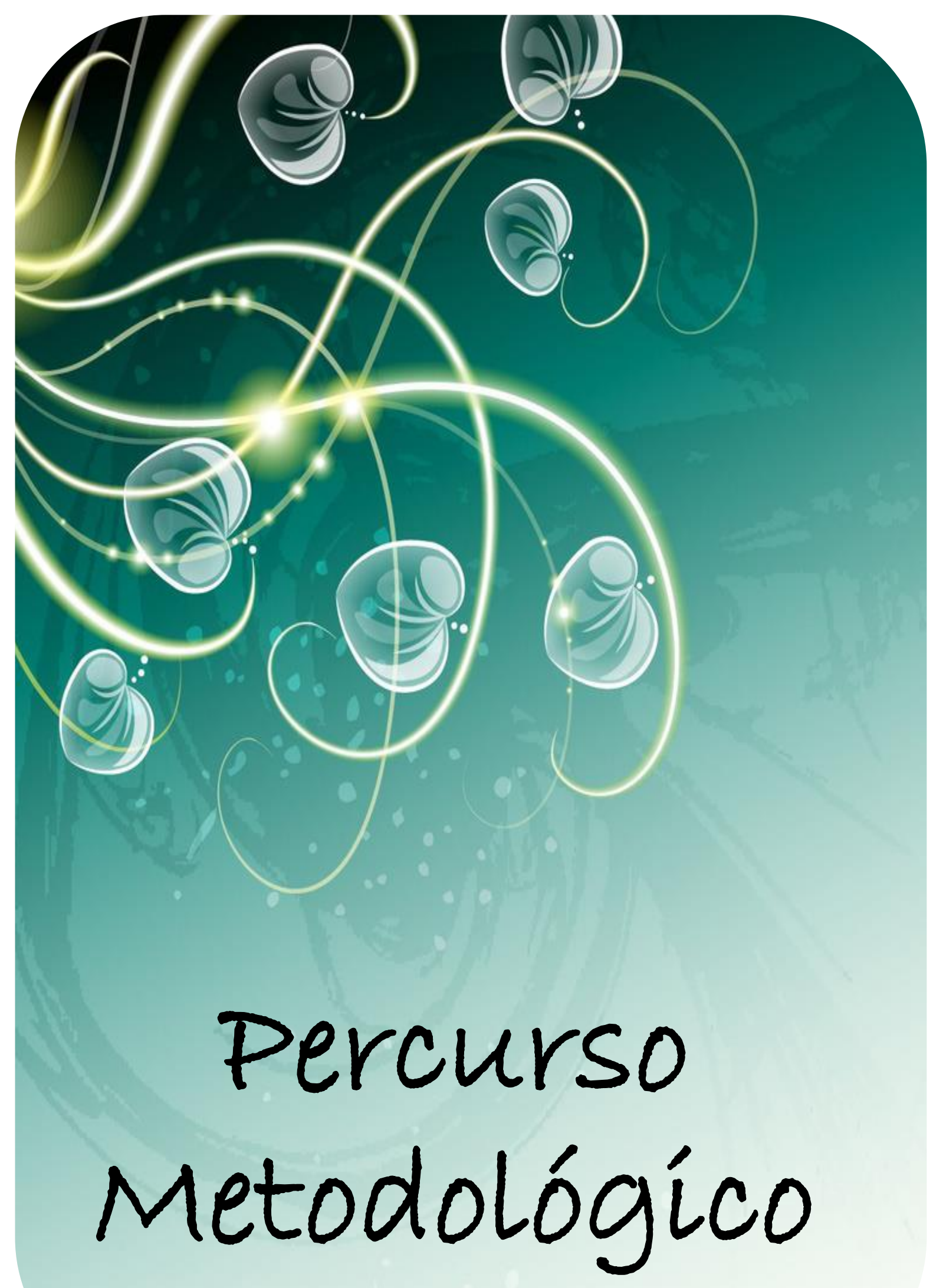




\section{PERCURSO METODOLÓGICO}

\subsection{Tipo de Estudo}

Trata-se de um estudo de natureza qualitativa, em virtude da possibilidade de investigar determinada realidade social ultrapassando sua superficialidade e indo além de dados quantificáveis. A abordagem qualitativa possibilita visualizar o objeto de estudo considerando seus condicionantes, sua especificidade e as relações que o permeiam, permitindo analisá-lo e interpretá-lo. Além disso, esta abordagem é capaz de incorporar a questão do significado e da intencionalidade como inerente aos atos, às relações e às estruturas sociais, sendo essas últimas tomadas tanto no seu advento quanto na sua transformação e nas construções humanas significativas (MINAYO, 2010).

A pesquisa qualitativa possibilita uma visão do indivíduo inserido em determinado contexto e realidade que são potenciais de transformação do ambiente e da sociedade na qual faz parte. Esse tipo de abordagem tem como pressuposto fundamental a investigação de fenômenos humanos os quais são repletos de singularidades que, por sua vez, permitem aos indivíduos atribuir significados aos fatos e às pessoas em interações sociais que podem ser descritas e analisadas e não mensuradas quantitativamente (CHIZZOTTI, 2003). O pesquisador é convidado a compreender profundamente a realidade que emerge da percepção e experiência de vida dos informantes e dessa forma, a quantificação se torna desnecessária, pois não capta a representatividade e a dinâmica presente no discurso do sujeito.

Para Minayo (2010), a pesquisa qualitativa, por se ocupar dos significados, ganha espaço na atualidade visto que trabalha com a subjetividade do indivíduo por meio do fortalecimento da introspecção do homem e da observação de si mesmo, fazendo com que saltem aos olhos, questões não alcançadas pelos métodos quantitativos.

A subjetividade da temática relacionada aos sentidos do trabalho fez com que fosse adotada a abordagem qualitativa haja vista a possibilidade de abarcar aspectos da psique e do comportamento humano e assim, trouxe à tona aspectos psicológicos revelados pelo indivíduo. Considerando que essa pesquisa buscou captar a subjetividade de profissionais da saúde, a pesquisa qualitativa permitiu trabalhar com o universo de significados, motivações, aspirações, crenças, valores e atitudes, o que corresponde a um espaço mais profundo das relações dos processos e dos fenômenos (YIN, 2010). 
Considerando o exposto, ressalta-se que o sentido do trabalho é um objeto subjetivo, dinâmico e condicionado a determinado contexto e, portanto, foi coerente utilizar um percurso metodológico que abarcasse as singularidades dos profissionais e representações que estes possuíam acerca do sentido do trabalho que realizam.

\subsection{Cenário do estudo}

O cenário deste estudo foi o Centro de Terapia Intensiva (CTI) de um Hospital Universitário localizado na cidade de Belo Horizonte, Minas Gerais.

O hospital, cenário deste estudo, foi inaugurado em 1998 com intuito de possibilitar a regionalização do atendimento de urgência e emergência e a descentralização desses serviços com o objetivo de criar uma rede integrada de cuidado, sendo uma instituição 100\% inserida na rede de saúde pública. Iniciou-se sendo gerenciado pela Fundação Hospitalar do Estado de Minas Gerais (FHEMIG) e, a partir de 2005, foi feita uma parceria com a Universidade Federal de Minas Gerais (UFMG) e, tendo como referência essa universidade, a Fundação de Desenvolvimento da Pesquisa (FUNDEP) assumiu a gestão do hospital, permanecendo até hoje. A parceria UFMG e FUNDEP, além de promover a ampliação do papel social do hospital nas políticas públicas de produção da saúde e do ensino, aumentou também, a integração com a sociedade e com o Sistema Único de Saúde (SUS) (HRTN, 2013). A concretização desse projeto possibilitou a inserção de residentes, alunos e docentes de diversas unidades acadêmicas nas práticas diárias do hospital.

O Hospital Universitário se caracteriza pela junção entre ensino, pesquisa e assistência à saúde. Além disso, apresentam características de hospitais de grande porte para o atendimento de alta complexidade, com equipamentos e tecnologia avançada para exames e intervenções contando com altos investimentos governamentais. Se tratando de um hospital vinculado à UFMG as oportunidades são ainda maiores, como a presença de estagiários de vários cursos da saúde, o ambiente ser permeado por pesquisas científicas, de extensão e de outras naturezas.

O Hospital Universitário é um ambiente no qual são estabelecidas relações múltiplas, haja vista que ele está ligado à instituição de ensino. Logo, são centros de formação de recursos humanos e de desenvolvimento de tecnologia para a área de saúde (BRASIL, 2009). Portanto, os profissionais que atuam nessas instituições precisam articular as atividades de ensino e assistência para que aconteçam concomitantemente, além de criar possibilidades para 
que uma equipe de profissionais diversificada se relacione de forma integrada em prol dos objetivos de ensino, pesquisa e assistência propostos pelo hospital.

O Centro de Terapia Intensiva (CTI) é um setor alocado no hospital destinado ao atendimento de pacientes críticos que necessitam de cuidados específicos, contínuos e de alta complexidade. A opção pelo Centro de Tratamento de Terapia Intensiva foi devido às peculiaridades deste setor no qual predominam tecnologias duras em saúde com atividades que demandam articulação e trabalho em equipe (tecnologias leves). A estruturação física do espaço propicia relações mais próximas, tanto entre profissionais quanto entre profissionais e pacientes/familiares, sendo um local no qual os profissionais lidam com um momento crítico vivenciado pelo paciente convivendo com a dor e sofrimento deles e de seus familiares. Ademais, o CTI se caracteriza como um ambiente estressante devido ao risco iminente de morte, aos dilemas éticos que são constantes e intensos, além do assédio moral passível de ocorrer. De acordo com Fischer (1996) esse lócus se caracteriza como uma unidade complexa que possui um "sistema peculiar de vida interna, onde todas as esferas da viver social e do conviver grupal ocorrem nos limites do mesmo espaço físico, configuram as condições propícias para a formação e manutenção de padrões culturais específicos (...)” (FISCHER, 1996, p.70).

O CTI, se comparado a outros setores do hospital, é permeado por grande aporte tecnológico sendo um setor onde impera a utilização da tecnologia dura em saúde. Essa situação pode deslocar a atenção dos profissionais das relações interpessoais (tecnologias leves) interferindo na assistência à saúde. Nesse sentido, Silva e Ferreira (2009) afirmam que no CTI as tecnologias em saúde trazem repercussões tanto para o cuidado ao paciente quanto para o profissional, além de produzir saberes que influenciam as ações dos profissionais. Ademais, esse ambiente também é estigmatizado por clientes e familiares, em face da complexa tecnologia, fazendo com que eles articulem o aparato tecnológico à noção de gravidade do paciente desencadeando o medo e a aproximação com a morte (SILVA; FERREIRA, 2009).

Além das peculiaridades apresentadas, o CTI exige a atuação de uma equipe multiprofissional que precisa estar preparada para atuar em um ambiente de plantões agitados, necessitando de atenção rigorosa e monitorização constate. Outro aspecto que merece destaque é a questão da morte, considerada um dos aspectos mais difíceis de lidar além de ser um fator estressante para a equipe uma vez que demonstra a impotência dela diante de determinadas situações do cotidiano de trabalho (LEITE; VILA, 2005; SILVA; FERREIRA, 2009). 
Desse modo, realizar um estudo sobre o sentido do trabalho em um ambiente com tais características tornou o trabalho mais instigante e relevante.

\subsection{Sujeitos do estudo}

Os sujeitos deste estudo foram profissionais da saúde que atuavam na assistência direta ao paciente no CTI do Hospital Universitário cenário dessa pesquisa. Participaram do estudo enfermeiros, técnicos de enfermagem, médicos, fisioterapeutas, nutricionista, psicóloga e fonoaudióloga.

Como critérios de inclusão estabeleceu-se o tempo de atuação dos profissionais na unidade, o vínculo empregatício com a instituição e o turno de trabalho. Assim, definiram-se como sujeitos, profissionais com mais de um ano de atuação na unidade, que não ocupassem cargo de ferista do CTI (profissionais que cobrem férias dos efetivos do CTI) e que assumissem o plantão diurno. O período de um ano foi determinado por entender que profissionais com um tempo maior de atuação na assistência no CTI poderiam contribuir com informações diferenciadas e fidedignas, uma vez que o sentido do trabalho se constrói ao longo do tempo, é dinâmico e depende da realidade na qual o sujeito vivencia. A exclusão dos feristas decorreu do fato desses trabalhadores não permanecem no setor por longos períodos, estabelecendo relações diferenciadas com a instituição e com a equipe sendo, muitas vezes, enfraquecidas podendo provocar distorções quanto aos sentidos atribuídos ao trabalho em comparação aos demais profissionais. Quanto à exclusão dos profissionais do plantão noturno, acredita-se que a dinâmica, as relações e o quantitativo de profissionais poderiam produzir percepções diferenciadas a respeito dos sentidos do trabalho se comparado aos profissionais do diurno.

Os sujeitos que atenderam os critérios de inclusão foram escolhidos intencionalmente. Dessa forma, participaram da pesquisa 1 psicóloga, 1 nutricionista, 1 fonoaudióloga, 7 enfermeiros, 7 técnicos de enfermagem, 7 médicos e 7 fisioterapeutas, totalizando 31 sujeitos. Ressalta-se que foi necessário estabelecer a mesma quantidade de profissionais de cada categoria profissional a fim de que o sentido atribuído ao trabalho fosse uma construção coletiva e não tendenciosa para uma categoria profissional por terem participado quantidade de profissionais diferentes. Dessa forma, como a equipe de fisioterapeutas contava com 9 profissionais, sendo 2 desses feristas, o máximo de profissionais que contemplariam os outros critérios de inclusão seriam 7, o que de fato aconteceu. Portanto, ficou estabelecido que o total 
de sujeitos por categoria profissional seria de 7 , desde que cumprissem os critérios de inclusão previamente determinados.

Ainda no sentido de não haver interferência na interpretação e análise dos dados, os sujeitos foram identificados pela letra "E" de entrevistado e o número correspondente da ordem na qual as entrevistas foram realizadas. Essa estratégia visou a não influência da categoria profissional na atribuição do sentido do trabalho visto que o objetivo deste estudo foi identificar o sentido atribuído ao trabalho no CTI pelo coletivo e não por uma categoria específica.

\subsection{Coleta de dados}

A coleta de dados foi realizada durante o mês de junho de 2013 e foi organizada da seguinte forma: 1) no primeiro momento foi aplicado um questionário estruturado para identificar o perfil dos sujeitos da pesquisa (APÊNDICE B) e; 2) no segundo momento foram realizadas entrevistas gravadas seguindo um roteiro semiestruturado com questões abertas (APÊNDICE C) e posteriormente, como parte da entrevista, foi utilizada a Técnica do Gibi (APÊNDICE D).

Para a realização da coleta de dados foi feito o contato previamente com a coordenação de cada categoria profissional no qual foi apresentado o projeto de pesquisa. Após a anuência dos coordenadores, buscaram-se os sujeitos que cumpriam os critérios de inclusão do estudo e assim, foi feito o contato com o objetivo de explicar a pesquisa e convidá-los a participar. O horário e o local de entrevista foram escolhidos de acordo com a opção apresentada por cada participante. Os dados foram coletados até o esgotamento das reflexões do sujeito acerca do objeto de estudo, de acordo com os instrumentos de coleta de dados.

Quanto aos instrumentos utilizados na coleta de dados, ressalta-se que a entrevista foi escolhida por ser capaz de obter dados objetivos e subjetivos sendo que os valores e as reflexões do sujeito são imprescindíveis para responder aos questionamentos deste estudo (MINAYO, 2010). O roteiro semiestruturado permite ao pesquisador ter uma participação ativa no processo de entrevista podendo ultrapassar as questões pré-estabelecidas no roteiro, quando necessário. Além disso, permite que o entrevistado discorra sobre o tema proposto, sem respostas ou condições pré-fixadas pelo pesquisador (MINAYO, 2010).

Para a realização da Técnica do Gibi, foi disponibilizado o último volume do Almanaque da Turma da Mônica publicado no período de realização das entrevistas sem 
qualquer alteração. O gibi foi escolhido de forma aleatória para que as figuras nele contidas não sofressem interferência ou julgamento por parte do pesquisador. O tipo gibi utilizado foi o mesmo para todos os sujeitos da pesquisa e foram aceitas figuras presentes em toda a revista tipo gibi fornecida, inclusive da contracapa, sendo respeitado o direito de escolha do sujeito de pesquisa (VON RANDOW, 2012).

Durante a realização da Técnica do Gibi foi solicitado ao entrevistado que representasse por meio de uma figura a complementação da seguinte afirmação: "Um trabalho que tem sentido...”. Em seguida, foi solicitado que discorresse acerca do motivo da escolha da figura. Posteriormente, o sujeito foi convidado a repetir o mesmo processo com a seguinte afirmação: “Um trabalho que não tem sentido...". Ressalta-se que a figura foi um recurso auxiliar para que os sujeitos, após a realização da entrevista, elaborassem acerca das questões relacionados ao sentido do trabalho. Os depoimentos oriundos dessa técnica foram incorporados à análise dos dados como parte da entrevista com roteiro semiestruturado.

A Técnica do Gibi foi uma estratégia lúdica utilizada para auxiliar os sujeitos a expressarem suas reflexões e representações por meio de figuras de revistas do tipo gibi. De acordo com Pessoa (2010), as historias em quadrinhos são consideradas multiartes que se utilizam de monoartes como o desenho, a escrita e a narrativa para gerar um meio de comunicação que ao mesmo tempo é de massa e subjetivo, já que sua leitura é um exercício individual. Dessa forma, as figuras escolhidas pelos sujeitos representou a visão de mundo de cada um, sendo uma leitura individual de modo que eles foram capazes de elaborar um discurso próprio e não apenas "falas prontas" criadas no ambiente de trabalho e compartilhadas pela equipe de trabalho.

A técnica do Gibi, utilizada por Arreguy-Sena, Rojas e Souza (2000) em sua pesquisa com abordagem qualitativa, proporcionou ao sujeito entrevistado um momento de descontração, seguido de uma proposta de reflexão sobre o trabalho que realiza. Essa estratégia também se justifica uma vez que as revistas do tipo gibi são, no Brasil, representações de histórias em quadrinhos capazes de propiciar situações e representações da realidade atual e de contextos vivenciados pelos sujeitos.

Os depoimentos dos sujeitos foram, então, gravados e transcritos na íntegra após a assinatura, por parte dos entrevistados, do Termo de Consentimento Livre e Esclarecido (APÊNDICE A) contendo os objetivos e as finalidades do estudo e o compromisso de anonimato e do uso dos dados para a produção técnico-científica.

Além dessas estratégias de coleta de dados, foi realizada também a observação (não participante) registrada em diário de campo na forma de notas de campos, as quais continham 
anotações acerca da percepção da pesquisadora no momento da coleta de dados. Assim, foram captadas impressões sobre a vivência da coleta de dados e a própria observação de situações do cotidiano e espaço de trabalho. As notas de campo foram utilizadas no decorrer da análise como forma de contribuição para compreensão dos depoimentos, e também, da atribuição do sentido ao trabalho.

\subsection{Análise dos dados}

Para a análise dos depoimentos oriundos da entrevista com roteiro semiestruturado e da Técnica do Gibi foi utilizada a técnica de análise de conteúdo. Segundo Bardin (2009), essa estratégia consiste em um conjunto de técnicas de análise das comunicações, visando obter a essência dos relatos por procedimentos sistemáticos e objetivos e a descrição de conteúdo das mensagens, isto é, "um conjunto de técnicas de análise das comunicações que utiliza procedimentos sistemáticos e objetivos de descrição do conteúdo das mensagens." (BARDIN, 2009, p 40).

Historicamente, a análise de conteúdo caracteriza-se como uma técnica que objetiva superar o senso comum e o subjetivismo da interpretação para atingir uma análise crítica diante de textos, biografias, observação ou entrevistas. Do ponto de vista operacional, parte-se de uma literatura de primeiro plano para atingir um nível mais aprofundado (aquele que ultrapassa os significados manifestos). Para isso, a análise de conteúdo, em termos gerais, relaciona estruturas semânticas (significantes) com estruturas sociológicas (significados) dos enunciados, articula a superfície descrita e analisada dos textos com os fatores que determinam suas características, quais sejam, variáveis psicossociais, contexto cultural e processo de produção da mensagem (MINAYO, 2010).

Ainda, a análise de conteúdo possui como objeto a fala em seu aspecto individual e em ato da linguagem. Assim, procura compreender os sujeitos e/ou o ambiente em que ele está inserido em um determinado momento buscando aquilo que está por trás das palavras e outras realidades por meio da mensagem transmitida pela fala (BARDIN, 2009). Logo, nesta técnica a subjetividade dos sujeitos está presente levando em consideração a individualidade do depoimento de cada um.

Considerando o sentido do trabalho, objeto deste estudo, esta técnica permitiu alcançar a complexidade e significados da fala dos sujeitos de forma coerente com a proposta. Assim, a 
análise dos dados foi feita seguindo-se três pólos cronológicos: a pré-análise; a exploração do material; o tratamento dos resultados, inferência e interpretação (BARDIN, 2009).

A pré-análise foi a fase de organização do material em si sistematizando as ideias iniciais. Nesta etapa ocorreu a preparação do material na qual se realizou a leitura flutuante (primeira leitura do documento deixando-se invadir por impressões e orientações) e exaustiva das entrevistas buscando conhecer, analisar e definir os principais pontos chamados de corpus. O corpus foi constituído por meio do desmembramento dos textos em unidades e o agrupamento delas por semelhança caracterizando a delimitação do material.

A fase de exploração do material consistiu na codificação dos pontos identificados na primeira fase e a sua categorização. Na codificação foi feito a correspondência entre as unidades identificadas na fase anterior, atingindo uma representação do conteúdo e de sua expressão. Na categorização, os dados brutos, chamados de corpus, foram transformados em dados organizados uma vez que as unidades são agrupadas por suas características comuns. A categorização é a fase que define os resultados sendo feita diante de dois critérios principais, a repetição e a relevância, e tem como objetivo produzir a representação dos dados.

O critério de repetição consiste na atividade de evidenciar as reincidências, considerando todas as ocorrências nos discursos. Por outro lado, no critério da relevância, consideram-se outros aspectos mencionados pelos sujeitos da investigação sem que, necessariamente, haja repetição no conjunto do material coletado, "mas que, na ótica do pesquisador, constitui-se de uma fala rica ao confirmar ou refutar hipóteses iniciais da investigação" (TURATO, 2003, p. 446).

O tratamento dos resultados, inferência e interpretação foi a última fase na qual os dados categorizados foram tratados de forma a ter significativos, propiciando inferências e interpretações ou descobertas inesperadas (BARDIN, 2009). A inferência foi a fase na qual se realizou a dedução dos dados pelo raciocínio conferindo significados aos dados pela conclusão a partir de estudos realizados previamente. Após, foi feita a interpretação dos dados buscando-se aquilo que está oculto, além do observável nos dados. O importante nesta fase foi não fazer o julgamento dos achados visto que é uma expressão do sujeito e não cabe ao pesquisador defini-la como certa ou errada. Dessa forma, surgiram categorias empíricas centrais.

Ao visualizar que os profissionais de saúde conferem sentido ao trabalho de forma multifacetada, isto é, ele é elaborado por múltiplos fatores desde a estrutura objetiva da organização até a subjetiva, utilizou-se na análise final dos dados a perspectiva do sentido do trabalho elaborada por Morin, Tonelli e Pliopas (2007) como eixo norteador para as 
categorias empíricas centrais. Dessa maneira, os resultados foram elaborados tomando-se como base as dimensões do sentido do trabalho esquematizadas por Morin, Tonelli e Pliopas (2007) e a literatura contemporânea sobre o tema, dos quais emergiram as seguintes categorias analíticas: dimensão individual, dimensão social, dimensão organizacional e dimensão fazer cotidiano.

\subsection{Aspectos Éticos}

O estudo foi aprovado pela Câmara do Departamento de Enfermagem Aplicada da Universidade Federal de Minas Gerais. Após, foi aprovado pelo Núcleo de Ensino, Pesquisa e Extensão (NEPE) do Hospital cenário (Parecer n 08/2013) (ANEXO B) e pelo Comitê de Ética em Pesquisa de Seres Humanos da Universidade Federal de Minas Gerais (COEPUFMG) (Parecer $n^{\circ}$ 329.009) (ANEXO A) em conformidade com a Resolução do Conselho Nacional de Saúde 466/12 que discorre sobre as diretrizes e normas regulamentadoras de pesquisa envolvendo seres humanos do Ministério da Saúde (BRASIL, 2012). Destaca-se que foram reservados todos os direitos dos profissionais, garantindo-lhes a liberdade de recusar a participar ou retirar seu consentimento no decorrer do trabalho.

Considerando os aspectos éticos relacionados aos sujeitos envolvidos na pesquisa, os sujeitos participantes preencheram e assinaram o Termo de Consentimento Livre e Esclarecido (APÊNDICE A) assegurado o caráter anônimo das entrevistas e da instituição. A participação dos sujeitos nesta pesquisa ocorreu de forma voluntária e todas as informações e esclarecimentos a respeito do estudo foram devidamente prestados. 


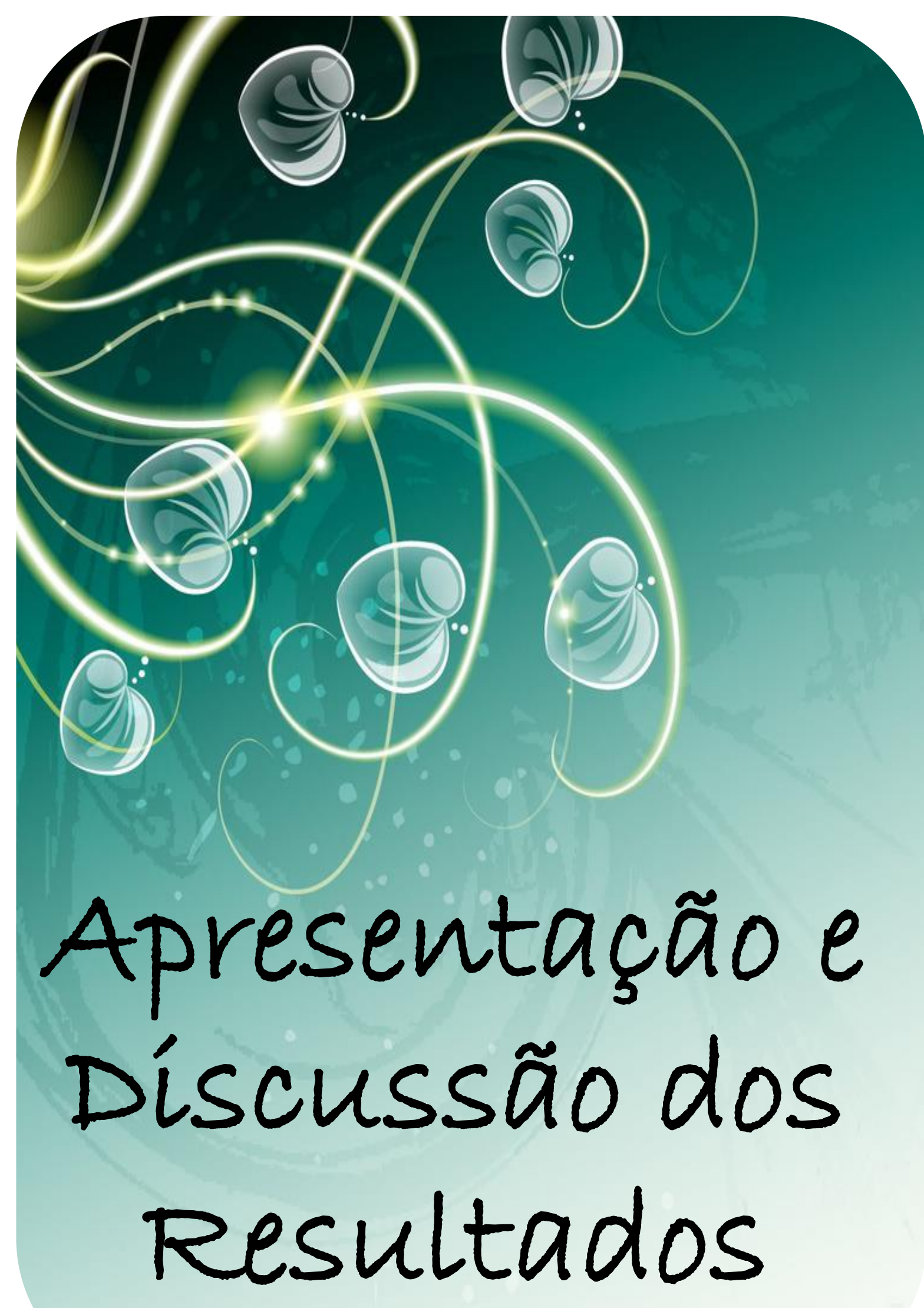




\section{APRESENTAÇÃO E DISCUSSÃO DOS RESULTADOS}

\subsection{Perfil dos sujeitos da pesquisa}

A despeito dos sujeitos da pesquisa, o perfil dos mesmos está apresentado na Tabela 1. Ressalta-se que foram entrevistados 31 profissionais da saúde que atuavam no CTI de um Hospital Universitário, entre eles: 7 fisioterapeutas, 7 médicos, 7 enfermeiros, 7 técnicos de enfermagem, 1 psicóloga, 1 nutricionista e 1 fonoaudióloga.

A maioria dos sujeitos é do sexo feminino $(n=24)$, a maior parte possui idade entre 28 e $33 \operatorname{anos}(36 \%)$ e entre 22 e 27 anos (29\%). Com relação ao estado civil, os profissionais entrevistados são predominantemente solteiros (58\%), sendo 35\% casados e $6 \%$ divorciado e, também, não possuem filhos $(77 \%)$.

Percebe-se pelo perfil dos profissionais que eles são, relativamente, recém-formados uma vez que $52 \%$ concluíram a graduação entre 1 a 5 anos atrás e, além disso, são predominantemente egressos de instituições privadas (65\%). A maioria dos profissionais realizou algum tipo de capacitação profissional (71\%), entre elas destacam-se: a especialização, o mestrado, a residência ou aperfeiçoamento profisssional realizado pelos técnicos de enfermagem. Salienta-se que, todos os profissionais fisioterapeutas e médicos entrevistados realizaram pós-graduação, respectivamente, em Fisioterapia Cardiorrespiratória (Fisioterapia Respiratória com ênfase em Terapia intensiva) e Terapia Intensiva haja vista que era um critério para a seleção de pessoal dessas categorias profissionais para atuarem no setor. Essa condição, entretanto, era exclusiva da categoria profissional Médica e da Fisioterapia, não sendo exigido esse nível de especialização, então, para os demais profissionais da saúde que atuavam no CTI.

Além disso, possuem pouco tempo de atuação na instituição cenário deste estudo, entre 1 ano a 5 anos (77\%), desses que atuam entre 1 a 5 anos, 38\% possuem de 1 a 2 anos de tempo de serviços. Ademais, a maioria trabalha apenas na instituição cenário do presente estudo 51\%, 39\% trabalham em dois empregos, e 10\% possuem três empregos. Destaca-se que a maior parte dos profissionais (48\%) atua em uma carga horária de 36 horas semanais, $29 \%$ possuem a jornada de trabalho de 30 horais semanais, $6 \%$ de 40 horas semanais e $3 \%$ de 44 horas semanais. 
Tabela 1 - Perfil dos sujeitos da pesquisa realizada no CTI de um Hospital

Universitário, Belo Horizonte, 2013.

\begin{tabular}{|c|c|c|}
\hline Variáveis & $\mathbf{n}$ & $\%$ \\
\hline Sexo & & \\
\hline Feminino & 24 & 77 \\
\hline Masculino & 7 & 23 \\
\hline \multicolumn{3}{|l|}{ Idade (anos) } \\
\hline $22 \geq 27$ & 9 & 29 \\
\hline $28 \geq 33$ & 10 & 36 \\
\hline $34 \geq 39$ & 6 & 19 \\
\hline$\geq 40$ & 6 & 19 \\
\hline \multicolumn{3}{|l|}{ Estado Civil } \\
\hline Solteiro & 18 & 58 \\
\hline Casado & 11 & 35 \\
\hline Divorciado & 2 & 6 \\
\hline \multicolumn{3}{|l|}{ Filhos } \\
\hline Sim & 7 & 23 \\
\hline Não & 24 & 77 \\
\hline \multicolumn{3}{|c|}{ Instituição de Formação } \\
\hline Particular & 20 & 65 \\
\hline Privada & 11 & 35 \\
\hline \multicolumn{3}{|l|}{ Tempo de Formação } \\
\hline $1 \geq 5$ & 16 & 52 \\
\hline $6 \geq 11$ & 7 & 23 \\
\hline $12 \geq 17$ & 5 & 16 \\
\hline $18 \geq 22$ & 3 & 10 \\
\hline \multicolumn{3}{|c|}{ Pós-Graduação/Capacitação } \\
\hline Sim & 22 & 71 \\
\hline Não & 9 & 29 \\
\hline \multicolumn{3}{|l|}{ Tempo de Serviço } \\
\hline $1 \geq 5$ & 24 & 77 \\
\hline $6 \geq 11$ & 4 & 13 \\
\hline $8 \geq 14$ & 3 & 10 \\
\hline \multicolumn{3}{|l|}{$\mathrm{N}^{\mathrm{o}}$ de empregos } \\
\hline 1 & 16 & 51 \\
\hline 2 & 12 & 39 \\
\hline 3 & 3 & 10 \\
\hline
\end{tabular}

Fonte: Elaborada com base nos dados da pesquisa para fins deste estudo. 


\subsection{Perspectiva Analítica do Sentido do trabalho}

A forma multifacetada como o sentido do trabalho é visualizada pelos profissionais vem sendo descrita em diversos estudos (HACKMAN; OLDHAM, 1975; MOW, 1987; MORIN, 2001; 2002; 2004; 2008; BORGES; FILHO, 2001; TOLFO; PICCININI, 2007; ARAÚJO; SACHUK, 2007; COUTINHO, 2009; ANTUNES, 2011), mas principalmente nos estudos de Morin, Tonelli e Pliopas (2007). A fim de elaborar uma perspectiva multiprofissional acerca do sentido do trabalho em uma unidade de cuidado intensivo, foi necessário buscar referenciais que apoiassem a organização das categorias analíticas desta pesquisa.

Neste sentido, destaca-se o estudo realizado por Morin, Tonelli e Pliopas (2007) as quais elaboraram as dimensões do sentido do trabalho esquematizando os fatores desencadeadores da seguinte forma: dimensão individual relacionado ao sentido que o trabalho assume para o profissional; a dimensão organizacional da relação do profissional com a organização e a dimensão social que é do profissional com a sociedade. A organização das dimensões dos sentidos do trabalho feita pelas autoras possibilita visualizar a complexidade da atribuição de sentidos ao trabalho e o papel que o trabalho na organização e a subjetividade do indivíduo desempenham para tal. Salienta-se que a utilização das dimensões propostas pelas autoras para esse trabalho sofreu algumas adaptações diante das diferenças de cenário e sujeitos entre as pesquisas, mas a essência delas foi mantida uma vez que se compatibilizaram com os dados encontrados.

No que concerne à organização de saúde, esta exige dos profissionais o resgate da subjetividade visto que é um campo permeado por relações interpessoais, entre os profissionais da equipe e desses com os usuários e familiares. Portanto, a subjetividade se expressa nesse cenário de forma acentuada e se torna um elemento importante quanto à atribuição de sentidos ao trabalho. Na perspectiva de Franco e Merhy $(2007$, p. 4) "todo o lugar no qual se produz práticas de saúde opera no campo dos processos de subjetivação, se expressando na construção de territórios de subjetividades comprometidos com a produção de certos sentidos para aquelas práticas".

O profissional da saúde constitui-se como sujeito no seu fazer profissional, além de ser o ator na produção do cuidado em saúde. Portanto, urge a necessidade de considerar a subjetividade para analisar o trabalho e as vivências nele para a constituição do sujeito como ele é, ou seja, sua subjetividade (MATOS; PIRES; RAMOS, 2010). A subjetividade que 
permeia o modo de ser, viver e trabalhar do profissional de saúde foi importante elemento para identificar nos depoimentos dos entrevistados uma quarta dimensão, fazer cotidiano.

A quarta dimensão, fazer cotidiano, surgiu na análise dos dados como um elemento adicional e complementar uma vez que ela permite ressignificar o trabalho, além de agregar elementos das três dimensões dos sentidos do trabalho propostas Morin, Tonelli e Pliopas (2007), representando a concretização do trabalho em ato, no fazer profissional. Portanto, não somente as dimensões individuais, organizacionais e sociais conferem sentidos ao trabalho dos profissionais da saúde, mas também, a dimensão fazer cotidiano que é criado pela dinâmica do trabalho bem como pela atuação profissional que se efetua nos processos relacionais. A dimensão fazer cotidiano é repleta de significados assim como é ativa na construção do sujeito que realiza e é modificado pelo trabalho.

Nesse sentido, Franco e Merhy (2007) expõem a importância do fazer profissional para se conhecer o significado da dinâmica do trabalho para os profissionais da saúde visto que este é um ambiente de produção:

\footnotetext{
Ora, se a vida se produz de forma tão dinâmica no interior das unidades de saúde, como se estas fossem habitadas por uma autopoiese própria dos organismos vivos, é necessário compreender a importância, no caso da produção da saúde, do significado revelador daquela dinâmica, dos processos de trabalho sob o olhar das tecnologias de trabalho na ação micropolítica do Trabalho Vivo em Ato, agregados dos processos de formação de subjetividades, dos afetos mútuos e dos fluxos de intensidades que operam na formação da realidade (FRANCO; MERHY, 2007, p.4).
}

Dessa forma, a perspectiva analítica deste estudo utilizou a estrutura e a essência de cada dimensão proposta por Morin, Tonelli e Pliopas (2007) como suporte para a agregação das categorias empíricas centrais do sentido do trabalho, entretanto, foi incluída uma nova dimensão, fazer cotidiano, que expressa a dinâmica e a concretização do trabalho na saúde. Nesta perspectiva, a Figura 2 apresenta a síntese da perspectiva analítica do sentido do trabalho na saúde proposta para este estudo. 
Figura 2 - Dimensões dos Sentidos do Trabalho na Saúde, Belo Horizonte, 2013.

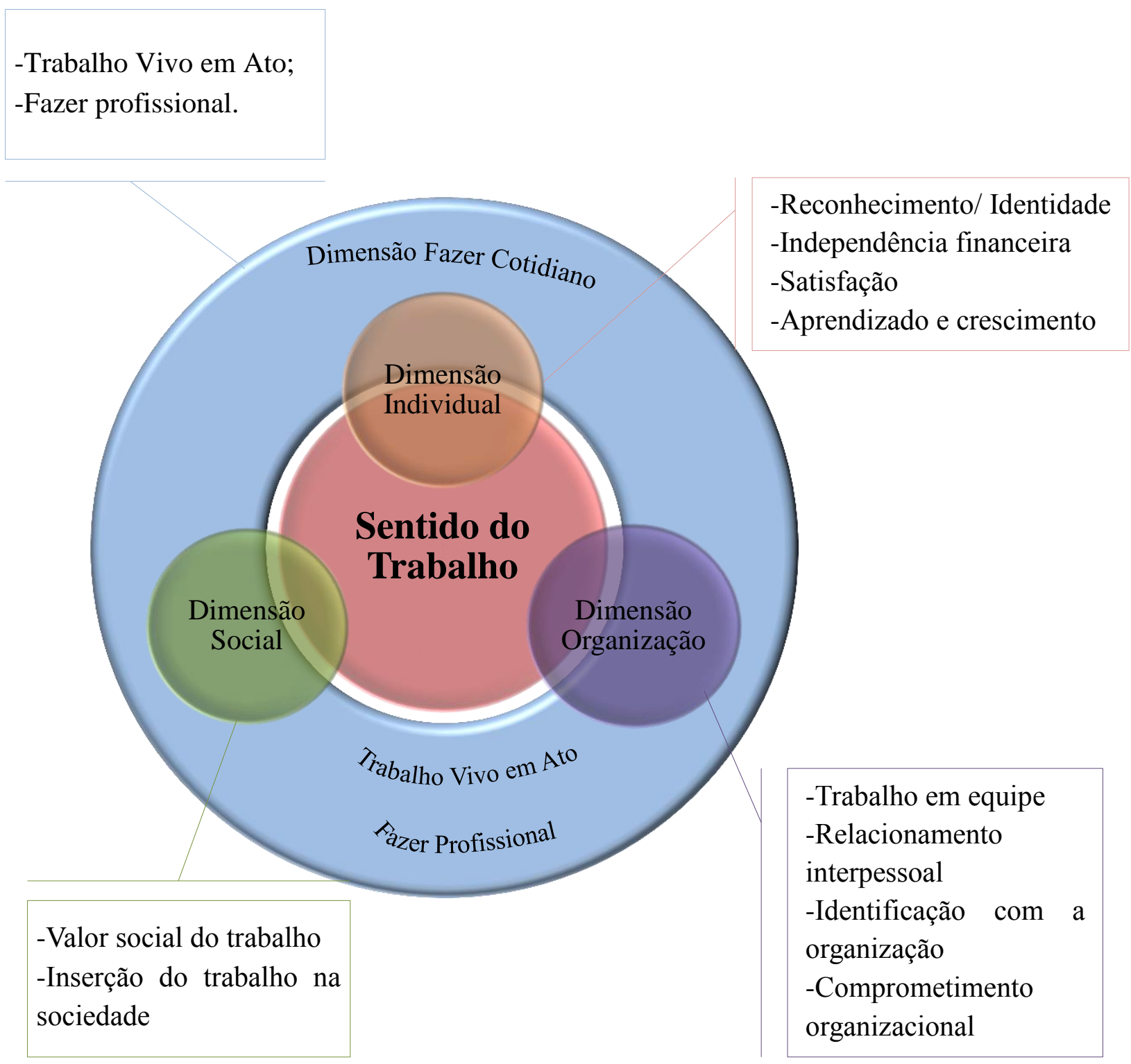

Fonte: Elaborada para fins deste estudo baseada no estudo de Morin, Tonelli e Pliopas (2007), na literatura e nos dados empíricos.

A dimensão individual está relacionada aos aspectos profissionais dos sujeitos que interferem significativamente na vida particular e profissional. É nesta dimensão que o indivíduo valoriza o reconhecimento profissional que recebe dos outros e de si mesmo a respeito do trabalho que realiza e assim, constituindo a configuração identitária desse profissional. Ademais, ele percebe que por meio do trabalho ele é capaz de crescer pessoal e profissionalmente, bem como obter prazer com o fazer profissional e ter independência financeira. 
A dimensão organizacional está associada à identificação do profissional com a organização na qual realiza o trabalho. Dessa forma, foi observada nessa dimensão a estrutura organizacional, o trabalho em equipe, os relacionamentos interpessoais inerentes ao trabalho e seu caráter social na vida do profissional, o comprometimento organizacional e o reconhecimento da instituição devido ao trabalho prestado.

A dimensão social analisa o valor social do trabalho bem como sua inserção na sociedade. Nesta seção, buscou-se apresentar como o profissional enxerga a contribuição do seu trabalho para a sociedade.

A dimensão fazer cotidiano enfoca o trabalho do profissional em ato, ou seja, o fazer profissional e os resultantes do mesmo, tais como: o prazer em ver o seu trabalho realizado e a recuperação do paciente, a percepção da efetivação e utilidade do trabalho no momento de sua realização. Ademais, abarca as formas de realizar o trabalho e de tratar o indivíduo com singularidade e humanidade.

Os resultados, portanto, foram organizados entre as quatro dimensões acima apresentadas, ressaltando ser uma divisão didática em razão de essas dimensões coexistirem nos sentidos do trabalho. Desse modo, algumas vezes, observa-se a presença de características de uma dimensão imersa em outra, o que não representa um viés visto que as dimensões não possuem limites claros e definidos, pelo contrário, elas convivem no cotidiano de trabalho dos profissionais. Dessa forma, esse capítulo será organizado em quatro subdivisões nomeadas pelas dimensões a fim de apresentar os aspectos importantes quando se trata dos sentidos do trabalho para profissionais da saúde que atuam no CTI.

\subsubsection{Os Sentidos do Trabalho - A Dimensão Individual}

Figura 3 - Imagem oriunda da Técnica do Gibi, Belo Horizonte, 2013

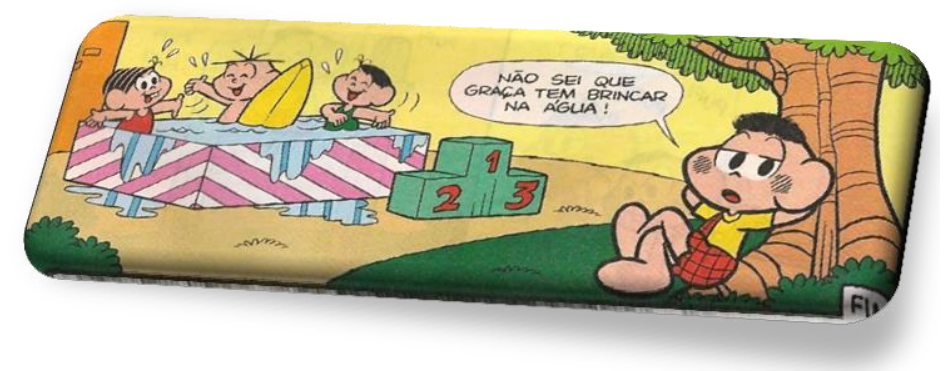

"Quando a gente trabalha demais, fica sobrecarregado demais, tem as vitórias do paciente, mas a vida pessoal fica assim, você fica afastado de tudo $e$ de todos e aí a vida perde o sentido." E11

Fonte: Dados coletados para fins deste estudo. 
O CTI é um setor hospitalar com algumas particularidades e, no hospital cenário deste estudo, observou-se que o setor é realmente um "mundo a parte" do restante do hospital. O espaço destinado ao CTI está instalado em uma ala mais tranquila se comparado ao restante do hospital, além de ter uma recepção exclusiva. O CTI foi estruturado em um espaço amplo no qual estão dispostas três salas de CTI independentes uma da outra, mas com acesso fácil, próximo e com posto de enfermagem central. No total são 30 leitos, uma farmácia satélite, expurgo, salas de materiais, uma sala para a coordenação de enfermagem, uma para a coordenação da fisioterapia e um descanso médico. O descanso dos outros profissionais fica em um espaço externo ao CTI, mas próximo a ele.

A descrição do ambiente justifica-se para demonstrar que neste micro espaço dentro de um hospital de grande porte se desenvolvem atividades intensas tanto assistenciais como relacionais, destacando-se as interpessoais, profissionais e da própria psique do profissional. Nesse cenário fechado, com características próprias e com relações extremamente próximas é que atua uma equipe multidisciplinar destinada exclusivamente para o setor, voltada para o atendimento ao doente crítico. No interior do CTI, os profissionais usufruem de uma estrutura física, bem como de recursos materiais estrategicamente alocados a fim de facilitar e agilizar o trabalho e, por isso, os profissionais passam longas jornadas dentro do setor convivendo e produzindo cuidado sem precisar recorrer ao ambiente externo. Dessa forma, os profissionais passam todo o tempo de trabalho no convívio com as mesmas pessoas, profissionais e pacientes, criando um ambiente exclusivo deles, com uma dinâmica própria e relações específicas, como um processo de socialização. De acordo com Dubar (2005), a socialização é uma forma de construção da identidade social que, normalmente, é concedida pela atividade profissional e nas quais o profissional precisar "tornar-se ator" (p.17).

Os profissionais da saúde passam por situações diferenciadas de socialização, pois lidam com a condição sine qua non do trabalho no CTI de ser em equipe e com a presença constante da família do enfermo o que cria um intenso processo de reconhecimento e aprovação do trabalho que realizam, sendo é importante para eles se tornarem atores do seu fazer:

Mas, o que a gente sempre busca é o reconhecimento profissional da gente ali, você ser reconhecida pelo o que você faz. E32 
O reconhecimento, como expõe Dubar (2005) é resultante de um processo social e, considerando a análise da identidade dos profissionais nas organizações como um constructo social o autor afirma que,

\begin{abstract}
A identidade humana não é dada, de uma vez por todas, no ato do nascimento: ela é construída na infância e, a partir de então, deve ser reconstruída no decorrer da vida. O indivíduo jamais a constrói sozinho: ele depende tanto dos juízos dos outros quanto de suas próprias orientações e autodefinições. A identidade é um produto de sucessivas socializações (DUBAR, 2005, p.25).
\end{abstract}

Portanto, é um processo que faz parte da conformação da identidade a qual, face aos depoimentos dos sujeitos deste estudo, se expressa na dualidade no social: identidade para si e para o outro de Dubar (2005), que pode ser esclarecida pelo próprio dualismo de sua definição, sendo "identidade para si e identidade para o outro são ao mesmo tempo inseparáveis e ligadas de maneira problemática" (p.135). Inseparáveis por que a identidade de si é concernente à do outro e ao seu reconhecimento, "nunca sei quem sou a não ser no olhar do outro" (p. 135). Problemática, pois, mesmo o indivíduo tentando se colocar no lugar do outro, não pode ter a certeza que a identidade para ele coincide com a identidade dele para o outro. O autor ainda reforça que "a identidade nunca é dada, ela sempre é construída e deverá ser (re)construída em uma incerteza maior ou menor e mais ou menos duradoura” (p.135).

O processo de socialização que ocorre no âmbito das organizações, e no caso específico do CTI, constitui a dinâmica da configuração identitária do profissional posto que no trabalho ele reconhece a si mesmo e também é reconhecido pelo outro, neste caso paciente, familiares, dirigentes e pelos próprios membros da equipe. Neste aspecto, os mecanismos de identificação se revelam como parte construtora da identidade de si visto que, como afirma Dubar (2005), a socialização é uma forma institucional de construção do Eu, ou seja, o indivíduo inserido em seu ambiente de trabalho permeado pela dimensão subjetiva das relações permite que ele se construa como sujeito diante de si e do outro, e como ser do seu fazer profissional, expressando a dualidade no social.

Os mecanismos de identificação são denominados atos de atribuição ou de pertencimento. Primeiramente, os atos de pertencimento estão relacionados à identidade atribuída pelo próprio indivíduo, "os que exprimem que tipo de homem (ou de mulher) você quer ser, isto é, a identidade para si” (DUBAR, 2005, p.137). Ainda de acordo com esse autor, os atos de pertencimento não podem ser analisados exteriormente as trajetórias sociais dos indivíduos, pois é o que garante a legitimidade subjetiva para o indivíduo, aquelas que realmente foram introjetadas e incorporadas por ele. Portanto, essa identidade é considerada 
pelo autor como "identidade social real", a identidade que pertence a ele, aquilo que ele percebe de si próprio.

Diante disso, os profissionais da saúde sujeitos deste estudo se responsabilizam pelo trabalho de forma intensa, prestam cuidados complexos, integral e de qualidade que, na maioria das vezes, resgata a vida de um ser humano e, portanto, precisam se reafirmar e serem reconhecidos naquilo que fazem para dar continuidade e se constituírem como sujeito social e profissional. Logo, o indivíduo precisa se reconhecer como profissional e se constituir em sua prática articulando as vivências para que atribua sentidos ao trabalho. No momento em que isso acontece, o profissional identifica sua atuação de forma coerente e segura, além de se sentir satisfeito por atuar em um local em que se reconhece como aquilo que ele se propôs, estudou e gosta de fazer:

Porque eu gosto muito de terapia intensiva. Eu acho que o ponto positivo que a gente tem de trabalhar aqui é porque o enfermeiro tem mais autonomia de trabalho, a gente consegue atuar mais, sabe!? Porque nas outras clínicas o enfermeiro tem que dar conta de tanta coisa que, muitas vezes, você não consegue atuar como enfermeiro. E4

Eu acho que é isso, você dar sentido a sua formação, botar em prática aquilo que você aprendeu. E6

E eu acho que até a questão de conseguir me ver mais profissional mesmo, porque quando a gente sai da faculdade a gente fica sempre com aquela incerteza: "Será que eu estou pronta pra assumir um trabalho, entrar no mercado de trabalho, comandar uma equipe?" Eu acho assim, eu tô conseguindo ir caminhando nesse sentido. E13

Eu acho que meu trabalho é bastante importante, o fato de ter ali um especialista, experiente, que tem vivência, que já tem, eu tenho um tempo de trabalho em terapia intensiva, já trabalhei como horizontal em outras instituições, eu trouxe essa minha vivência pra cá. Então assim, meu empenho, o meu estudo, o meu dia-a-dia, a forma como eu trabalho, essa dedicação, eu acho que ter a frente um intensivista como horizontal é algo que é imprescindível para o atendimento desse doente. (E31)

Percebeu-se que os indivíduos se reconhecem na atividade profissional além de se construir como sujeito ativo no seu fazer profissional dando sentido àquela ação e/ou à sua formação. Nesta perspectiva, Morin (2002) afirma que o trabalho auxilia o profissional a descobrir e formar sua identidade, assim como a organização possui um papel determinante 
nesta construção, pois as atividades e tarefas precisam ser claras, estruturadas e favoráveis ao indivíduo para que ele se reconheça e incorpore essas vivências à sua identidade. O papel da organização na construção da identidade do profissional e, consequentemente, na atribuição dos sentidos ao trabalho permite visualizar a necessidade das políticas de gestão de pessoas serem voltadas para as dimensões subjetivas do trabalho para que o profissional atue de forma coerente com as diretrizes organizacionais e o objetivo do trabalho seja alcançado com sucesso.

A despeito dos aspectos positivos apresentados, percebe-se que os profissionais não se reconhecem no fazer profissional, eles se sentem desmotivados e passam a questionar se estão trabalhando no lugar certo enfraquecendo o vínculo com a instituição. A identidade profissional é constantemente construída durante a formação e, no momento em que o profissional se depara com o serviço de saúde ocorre uma ruptura da identidade que pode ser causa sofrimento, insegurança e, consequentemente, o trabalho passa a não ter sentido, pois não há reconhecimento. Para Dubar (2005), a identidade é preciosa para o indivíduo e a perda dela representa alienação, sofrimento, e angústia.

A situação de não se reconhecer no fazer profissional e, consequentemente, a ruptura da identidade se destacou com os profissionais enfermeiros entrevistados para esse estudo. No último ano, o CTI do Hospital cenário deste estudo, passou por uma reformulação na prática cotidiana do enfermeiro. Antes, o enfermeiro era supervisor, não tinha que se responsabilizar pela assistência direta ao paciente, salvo as condutas exclusivas do enfermeiro, mas seu trabalho era de supervisão dos técnicos de enfermagem e do cuidado como um todo. Atualmente, esse mesmo enfermeiro deixou de ser exclusivamente supervisor e passou a ser o enfermeiro assistencial. $O$ enfermeiro atua na assistência direta e integral ao paciente, juntamente com um técnico de enfermagem assumindo três pacientes e realizando todos os cuidados, inclusive os que eram destinados somente aos técnicos de enfermagem.

Dessa forma, os profissionais enfermeiros estão vivenciando uma crise identitária (DUBAR, 2005; BRITO, 2004) expressa na contradição entre a sua prática cotidiana e a sua formação profissional. Existe então, uma ruptura na "identidade social real" destes enfermeiros, pois a mudança no processo de trabalho provocou uma visão deturpada de si mesmo perdendo o sentido que atribui a sua atuação e a formação profissional e, assim, ao trabalho:

Às vezes, eu fico triste de ver que tem matérias na faculdade que eu fiz e que hoje eu não uso. Eu não consigo aplicar. Por exemplo, a 
gente já pegou três pacientes com diarreia e única coisa que a gente fez foi limpar cocô, a manhã inteira isso. Isso tem dia que a gente fica muito mal. E4

Mas, eu não me vejo como enfermeiro. Do que eu estudei não. Eu me vejo como técnico de enfermagem que é o que a gente faz no momento. Estou muito insatisfeito pelo trabalho que eu realizo aqui apesar de gostar, mas eu queria ver o outro lado, o lado dá supervisão, da gerência. E isso eu não pude ver aqui nesses 1 ano e 4 meses. Por que é muito braçal o que a gente faz aqui. E5

Então, para mim eu acho que estou perdendo muito nesse sentido de supervisão, de ver como é o gerenciamento de uma unidade de saúde, de poder atuar em questões mais administrativas que são mais voltadas para o que a gente aprendeu no nosso curso e eu acho que são mais voltadas para enfermagem. Ultimamente eu tenho ficado bem questionando essa minha escolha, de ter ficado aqui se eu sou capaz de ter uma posição de gerência, de supervisão porque eu já estou acomodada aqui e do jeito que tá ficaria, sabe!? [...] Então, é como se a gente fosse uma mão de obra especializada, mas barata entre aspas porque a gente faz um trabalho técnico com o curso superior. E13

A equipe de enfermagem entra um hoje e sai outro amanhã. Assim, a equipe está mexendo muito, até mesmo porque, aqui o enfermeiro ele é assistencial, então eu acho que os meninos ficam desmotivados por formar e fazer, não desmerecendo os técnicos, mas eu acho assim, estudou a mais eu acho que fica completamente desmotivado de chegar aqui, entrar na assistência, ter que dar um banho, ter que trocar uma fralda e não ficar ali na supervisão, né?! Porque ele estudou foi pra isso. E32

Os depoimentos apontaram para a frustração dos enfermeiros no que concerne a expectativa da profissão no mercado de trabalho o que desmotiva o profissional enfermeiro, pois é uma ruptura em sua configuração identitária. Tal ruptura, é ainda mais acentuada face à fragilidade da profissão ao longo da história. Ainda, Dubar (2005) afirma que a inserção do indivíduo no mercado de trabalho é um momento crucial na construção da identidade, pois é do confronto do sujeito com o mercado de trabalho que ocorre a construção futura de si e de suas aspirações.

"É do resultado dessa primeira confrontação que dependerão as modalidades de construção de uma identidade "profissional” básica que constitua não somente uma identidade no trabalho, mas também e, sobretudo uma projeção de si no futuro, a antecipação de uma trajetória de emprego e a elaboração de uma lógica de aprendizagem, ou melhor, de formação" (DUBAR, 2005, p.149).

Percebeu-se, portanto, a existência de lacunas no fazer cotidiano de trabalho e a formação do profissional enfermeiro para atuar na prática exclusivamente assistencial. Essa 
situação interfere, ainda, no seu relacionamento com o técnico de enfermagem, haja vista a sobreposição de atividades e a indefinição de papéis e a atuação do enfermeiro em atividades de supervisão.

Eu sou enfermeiro assistencial e eu faço todos os procedimentos do enfermeiro e dos técnicos de enfermagem, nós atuamos juntos. Eu dou banho, faço medicação, eu troco, eu supervisiono, supervisiono assim (sinal de aspas). Alta é a gente que leva, pra fazer exame, tomografia a gente que faz esse encaminhamento. Dar orientação e advertência a gente faz também e depois vir e continuar trabalhando com pessoas ali, juntos. É bem complicado. Bem complicado mesmo. E5

Observa-se a necessidade de redefinições nas práticas do enfermeiro no âmbito organizacional e nos processos formativos para que ambos estejam coerentes e sincronizados. Além disso, os enfermeiros expõem que a problemática não está na mudança no processo de trabalho e sim, na forma como ela é feita, pois os outros profissionais não compreendem o papel do enfermeiro assistencial.

A faculdade não forma a gente para esse tipo de assistência que a gente presta. Então o que acontece? A gente chega despreparado, fora de uma realidade, então a gente chega para assumir uma coisa, na verdade, não é isso que o mercado agora está esperando da gente. Eu acho que o pior para o profissional é não estar preparado. A partir do momento que ele estiver preparado para assumir, eu acho que vai ser mais fácil. E15

Eu acho que tinha que fortalecer o sistema assistencial que está adotado porque não adianta nada você ter um sistema assistencial, e o resto do hospital não entender. Eu vejo que, muitas vezes, a visão de quem está de fora é que a gente não faz nada porque a gente tem três pacientes. E13

A respeito da configuração da identidade do profissional de saúde, ressalta-se que o processo dinâmico que a caracteriza demonstra a necessidade de transpor a inflexibilidade, pois como afirma Bauman (2005, p. 60) "uma identidade coesa, firmemente fixada e solidamente construída seria um fardo, uma repressão, uma limitação da liberdade de escolha. Seria um presságio da incapacidade de destravar a porta quando a nova oportunidade estivar batendo." Dessa forma, as mudanças não devem ser encaradas como um problema, mas como uma oportunidade de melhora, desde que seja feita de forma correta e planejada.

Ademais, sendo a identidade social/profissional um processo de constantes modificações - construção-desconstrução-(re)construção - baseado nas experiências individuais, no processo de formação e nas relações inerentes ao trabalho, refletem pois, o 
caráter social dessa configuração identitária, o que a caracteriza, como afirma Brito (2004), como um "eterno vir a ser".

A identidade para si e para o outro estão interligadas uma vez que o profissional reconhece a si mesmo pelo seu próprio olhar e por aquilo que ele acredita que o outro enxerga dele, portanto, um "reconhecimento recíproco" (DUBAR, 2005, p.100). Tal dualidade se encontra no processo de socialização com o outro, nas experiências e trajetórias de vida. Portanto, a identidade nunca é acabada, mas constantemente reformulada nas interações consigo mesmo e com o outro. No caso da identidade para o outro, o mecanismo de identificação é denominado de atos de atribuição que diz respeito à identidade atribuída pela outro, isto é, com "que tipo de homem (ou de mulher) você é" (DUBAR, 2005, p. 137). O ato de atribuição concerne na atribuição da identidade pela interação com o outro, sendo a instituição ou os agentes sociais, legitimado pela construção coletiva da identidade considerada pelo autor de "identidade social virtual". A configuração identitária ocorre por meio de processos relacionais, comunicativos, interacionais, ou seja, "implica fazer da qualidade das relações com o outro um critério e um elemento importantes da dinâmica das identidades" (DUBAR, 2005, p.141).

$\mathrm{O}$ autor ainda assevera que a identidade profissional requer que o indivíduo ingresse em relações de trabalho e que ele participe de ações coletivas inerentes às organizações. $O$ trabalho no CTI ele é absolutamente repleto de relações interpessoais, sejam elas profissionais ou sociais. Além disso, a própria estrutura física do setor propicia que as interações sejam mais próximas e intensas resultando em processos de construção e re(construção) da “identidade social virtual” uma vez que o profissional para atuar precisa da aprovação e da reivindicação da sua identidade para o outro.

Portanto, outro aspecto que faz com que o profissional atribua sentidos ao trabalho é o reconhecimento do seu trabalho pelo outro, isto é, a identidade conferida pelos indivíduos que interagem com ele, seja pelos profissionais da equipe multiprofissional, pelos pacientes e/ou familiares ou pela própria instituição. Necessário se faz a compreensão de que identidade profissional existe quando ela é reconhecida pela população e, o profissional, considerado como um verdadeiro ator desse processo precisa ser legitimado não somente por quem emprega, mas também por quem consome (DUBAR, 2005).

Neste estudo, foi considerada a visão geral do reconhecimento, visão esta relacionada àquela que o profissional da saúde possui de si mesmo e daquilo que ele acredita que o outro percebe dele. Portanto, pelos depoimentos dos sujeitos foram identificados traços da 
“identidade social virtual” visto que o indivíduo projeta sua visão também associada àquilo que ele pensa acerca do que o outro acha dele, o reconhecimento recíproco.

Apesar de ser identificado um discurso marcado por incertezas, o reconhecimento pelo outro foi observado nos depoimentos dos sujeitos desta pesquisa. O reconhecimento que o profissional acredita ter por parte da equipe multiprofissional e dos dirigentes do hospital reforça a identidade daquele que exerce, pois ele percebe que está fazendo um trabalho que colabora com a instituição e com os atores que atuam juntamente a ele. Pôde-se perceber esse aspecto na fala em que os sujeitos revelaram ter reconhecimento da sua profissão por parte de outra categoria profissional, do respeito pelo trabalho exercido e também, pelo próprio agradecimento verbalizado por profissionais, pela coordenação e diretoria:

Eu busco reconhecimento profissional da parte da sociedade né!? Quando eu falo sociedade, eu incluo o hospital, o reconhecimento adequado, eu incluo a sociedade na visão do fisioterapeuta como um item indispensável dentro da terapia intensiva, do nível ambulatorial, da saúde pública, nos postos. E29

Às vezes eu chego com o saco de óbito e meus colegas falam assim: "Busca o saco de óbito". Ai eu: "Já tá aqui". "Como você sabia?" Eu não sabia, eu tive uma percepção e adiantei, porque mesmo que não fosse já estava ai. E sou muito boa de acesso ai, os médicos falam: "ah, vou levar um presentinho pra você, porque se você não pegar é só central." Ai, eu gosto. Essa semana mesmo a (coordenadora) falou que a gerente do hospital, elogiou o meu trabalho e do meu colega. Ai eu falei: "Ah, que bom." Ela: "Tá vendo, a gente pensa que as pessoas não vê." Ai eu disse que, às vezes, o funcionário, o trabalhador quer remuneração financeira, isso é óbvio, mas quando chega um reconhecimento ai você também fica bem satisfeita né!? E23

Portanto, o profissional de saúde precisa perceber o reconhecimento daqueles que se "beneficiam" do seu trabalho, neste caso, dos pacientes e familiares em razão da utilidade do trabalho para o reestabelecimento da saúde, que se revela pela melhora, recuperação e também, da boa atuação do profissional no cuidado ao paciente. Neste estudo, o reconhecimento dos pacientes se expressa na satisfação daqueles que estão conscientes podendo se comunicar, dos familiares ao verem o trabalho se concretizando na melhora ou no estado em que encontram o paciente no leito durante as visitas e por meio dos reconhecimentos simbólicos demonstrados por presentes e agradecimentos formais:

Quando o paciente já fala e pode expressar alguma coisa, meu prazer é em vê-lo satisfeito. Igual ontem mesmo eu cheguei e tem um paciente que tem problema cardíaco sério que tá esperando transferência. 
Então, as meninas até brincam "Você fez amizade com a chefe da nutrição" porque ele sente muita fome e ai eu escuto lá do outro CTI: "Olha ele tá falando que a sopa hoje estava uma delícia" [...] Sem dúvida é aquele sorriso, é aquele agradecimento, aquela coisa assim que você fez diferença para ele naquele momento. E1

O momento de prazer que eu tive foi semana passada, um paciente muito grave que estava aqui me ligou agradecendo pelo atendimento. Um paciente assim que pedi o contato: "Ah, eu gostei do seu trabalho, você é um excelente funcionário." Uma família uma vez trouxe uma carta de agradecimento com o meu nome e colocou ali no mural. Mandou um e-mail para o hospital agradecendo o trabalho prestado. Isso eu fico muito feliz [...] Esses momentos de reconhecimento mesmo. Não só por causa da lembrança, de uma coisa, mas reconhecer o seu trabalho sabe?! Reconhecer que você prestou uma assistência de qualidade, que você é um bom profissional, que você procura dar o seu melhor mesmo sabendo de todas as dificuldades que a gente tem aqui, que não são poucas. Mas, isso me deixa muito feliz. E5

Igual, várias vezes eu já ouvi assim: "Ah, meu sonho é sair daqui e tomar um banho de chuveiro, mas esse banho que você me deu hoje foi..." Entendeu? Então assim, isso pra mim é muito importante, é muito válido. E9

Do sorriso das pessoas, de olhar pra mim e me agradecer e falar assim: "Oh minha filha, Deus te pague". "Oh minha filha, muito obrigada". [...] Então, isso é muito bom, nó eu fico muito feliz, disso eu ia sentir falta, dessa gratidão, desse agradecimento. E9

Então, o bom é você ver a família contente com a gente por ter cuidado bem dos parentes, entendeu?! Eles chegam, vê que você está cuidando, vê o paciente bem cuidado, ele sai satisfeito, sabe que a pessoa está sendo olhada, sabe que está em boas mãos. Isso é muito gratificando pra gente e pra família também. E21

A respeito da valorização e reconhecimento identificados, ocasionalmente os profissionais se sentem desmotivados e expressam a falta de reconhecimento pelo trabalho prestado tanto por parte da equipe multiprofissional quanto dos pacientes e familiares. Essa situação gera desmotivação, frustração, e desgaste para o profissional. A falta de reconhecimento é notada pela forma como se relacionam (entre os próprios profissionais e os pacientes/familiares com os profissionais) e pela falta de credibilidade em uma conduta tomada por determinado profissional:

Famílias ingratas, famílias problemáticas, porque a gente não tem como dar garantia de sucesso. A única coisa que o médico pode 
garantir é o meio, mas ele não tem como garantir o fim. Então, por mais que a gente às vezes faça o meio impecável, às vezes o fim é outro. E11

A gente não tem reconhecimento, entendeu!? Salarial e nem do próprio paciente, tem paciente que xinga, às vezes, que não tem paciência. A gente tem que ter consciência que o paciente está debilitado, mas o paciente não tem com a gente nenhum respeito não. E20

Olha, às vezes, eu acho que eu sofro quando o meu trabalho não é tão bem visto pelo outro. Quando ele não é tão reconhecido pela outra equipe isso é uma frustração. Então, eu acho que é um sofrimento, No dia a dia você percebe que, às vezes, o outro não reconhece o seu trabalho tão bem quanto deveria. Você indica uma coisa e o outro toma outra conduta. Então, isso é no dia a dia, não só comigo mais com tantas outras profissões também não médicas. E2

Primeiro porque a relação aqui é uma relação complicada. Eu falo assim, com a maior parte dos plantonistas, dos médicos, não é uma relação boa, porque às vezes você está tentando fazer o melhor, você não é reconhecido pela equipe. E não só pelos médicos, a gente tem problema até com os fisioterapeutas também alguns. Isso que já me chateou muito e que me frustrou muito. E14

Outra situação que enfraquece a construção e o fortalecimento da identidade dentro do CTI e, além disso, desarticula a atribuição de sentidos ao trabalho é a falta de reconhecimento por parte da sociedade da profissão exercida o que acarreta rupturas identitárias, pois o indivíduo questiona a contribuição do seu trabalho para a sociedade e a sua escolha profissional:

Infelizmente a nossa profissão não é valorizada, o ser humano em si não valoriza que a gente tá ali cuidando dele, infelizmente, nós seres humanos, não vou falar o ser humano porque um dia eu posso estar aqui né!? Mas, o ser humano quando ele está fragilizado no hospital ele fica muito nervoso, ele quer embora, ele não está nem aí se tem pessoas cuidando dele ou não. Então, eu acho que isso desmotiva um pouco a gente, não só o financeiro como isso também. E20

E um reconhecimento da sociedade também porque: "Ah, o que você faz?". "Eu sou engenheiro". Todo mundo sabe. "Eu sou advogado". Também, agora: "Eu sou enfermeiro". "O que você faz?". Isso me mata. "Mas, você dá banho?" Aí você tem que ficar explicando que tem uma diferença entre enfermeiro e técnico. Isso me incomoda muito porque tem quantos anos que existe a nossa profissão? $\mathrm{E}$ as pessoas ainda não sabem o que você faz. Isso me mata, me deixa muito triste. E5 
Mas, na maioria das vezes não reconhece, nem sabe que tem fisioterapia. "Mas, você trabalha no CTI, o que você faz?". E32

Percebe-se que, mesmo diante da dinâmica identitária, que ora proporciona momentos de reafirmação profissional e contentamento e ora de angústia no "ser ou não reconhecido" por aquilo que faz, os sujeitos sentem prazer em realizar o trabalho. Nesse sentido, Morin (2001, p.16) afirma que "o prazer e o sentimento de realização que podem ser obtidos na execução de tarefas dão um sentido ao trabalho". Portanto, é um fator motivador para o trabalho além de ser um dos pontos chaves na atribuição do sentido fazendo com que o profissional seja capaz de transpor alguns obstáculos que ele próprio considera negativo para continuar realizando as atividades de maneira coerente e condizente com seus princípios e valores:

Nossa, o que me faz continuar? Eu acho que é satisfação pessoal. A gente tem um ideal de continuar. E11

Eu acho que é prazer. Tudo o que a gente faz na vida tem que estar atrelado ao prazer. Se você não tem pra prazer no que faz não deve ser feito. E2

Porque eu gosto, porque eu gosto da atividade se não eu não estava aqui não. E30

Almeida e Pires (2007) consideram que o trabalho pode ser fonte de prazer quando a relação do homem com as atividades que realiza é favorável. O prazer apresentou-se nesse estudo atrelado a fatores internos do ambiente, à atividade em si, ao gostar do que faz e ao desenvolvimento de uma profissão escolhida:

É uma realização por estar fazendo o trabalho. Eu acho que isso que é o grande prazer. E6

Assim, nós trabalhamos no que nós gostamos mais. Eu gosto porque no dia que eu não gostar mais eu saio [...] Realização também porque é aquilo que eu gosto de fazer. Gosto do trabalhar. E10

Nossa, para mim, é tudo porque eu gosto muito do CTI. Eu gosto muito, então para mim é a área onde eu quero trabalhar o resto da minha vida, gosto muito. E17

O trabalho em si é muito bom, eu acho gratificante trabalhar. Eu acho que se eu fosse pra eu ficar fora do trabalho do CTI, da vida assim, eu não ia conseguir ser feliz não. E23 
Sim eu tenho prazer no que eu faço. [...] Satisfação mesmo né!? De estar fazendo aquilo que eu gosto de fazer. E25

Bonfim e Soares (2011) afirmam que o caráter subjetivo do prazer faz com que cada profissional tenha a sua idealização de prazer no trabalho, seja ele remuneração, ambiente físico, relação interpessoal, melhora do paciente, entre outras. Neste estudo, identificou-se nos depoimentos que o prazer está atrelado à realização profissional, ao trabalho com o paciente crítico e, principalmente, ao gostar do que faz e do trabalho do CTI.

Desse modo, os fatores ligados à satisfação em realizar a tarefa, consequentemente, implicam no crescimento e realização pessoal e profissional dos sujeitos. O prazer em realizar o trabalho acarreta o crescimento profissional, pois a dinâmica do setor e a complexidade dos pacientes do CTI exigem dos profissionais a constante busca pela atualização e aprendizado o qual é consequência do aprendizado com relações às doenças e procedimentos, da conquista em ocupar o espaço e dos resultados do trabalho, conforme observado nos depoimentos:

O significado pra mim eu acho que é uma conquista. Porque eu acho que nós somos a primeira fonoaudióloga implantada em Minas Gerais que atua exclusivamente no CTI. E2

Atualmente eu sinto que eu consigo dominar mais, conhecer os meus pacientes, entender mais sobre as doenças, a evolução da melhora, antibióticos que antes a gente ainda ficava meio perdido, exame físico, ausculta, tudo isso a gente aprimora. E4

Aqui me da uma bagagem muito grande, me capacita [...] É de crescimento mesmo, de aprendizado [...] Você lida com pacientes mais graves e o crescimento seu é maior. Você enrica mais de conhecimentos. E7

Então, o aprendizado aqui é muito grande, a pessoa que entra aqui, ela está preparada para lidar com qualquer setor, qualquer paciente, ela aprende muito. Acho isso importante. E17

Além da realização, eu busco essa experiência que é muito rica aqui [...] Então, o hospital ele me dá muita experiência de caso clínico, de construção de caso, de visões totalmente diferentes. Eu busco experiência e assim, uma coisa que acontece é experiência de vida e profissional. Realização porque é muito bom ter realização profissional. E22

É uma realização profissional cuidar do doente grave, com múltiplas variáveis. É um trabalho desafiador. Atende a uma necessidade minha 
de desafio, de conhecimento, de aprendizado, né?! Traz isso todos os dias. E30

Além disso, a complexidade do cuidado demandado pelos pacientes do CTI também se revela como fonte de prazer e realização profissional, uma vez que os profissionais se consideram competentes em atuar junto ao paciente grave:

(O trabalho no CTI) É minha paixão. É igual cachaça, fico sem não (risos). Para mim, é muito bom. Eu adoro [...] Proporciona muito prazer, eu acabei de entubar uma paciente sentada, isso é um negócio difícil de fazer. Então, quando você faz um procedimento complexo e dá certo. E11

Eu gosto dessa terapia intensiva, eu gosto desses conflitos que a gente vive, ai de repente o paciente parou a gente tem que salvar, eu gosto desses momentos de tensão de salvar o paciente. E16

Os achados corroboram com os de Almeida e Pires (2007) ao afirmarem que situações de urgência e emergência apresentam-se para os profissionais da saúde como desafiadoras proporcionando realização plena quando concluídas com êxito. Ademais, as autoras explicitam que trabalhar em unidade críticas, como no caso do CTI, confere uma valorização profissional maior, além de constituir-se como fonte de realização pessoal.

Nos depoimentos dos profissionais a realização pessoal revelou-se no crescimento como ser humano, tanto no fato de ajudar o próximo quanto nas experiências que os próprios pacientes compartilham:

Acho que é mais troca de experiência que a gente tem aqui, passa de pessoa, tipo assim, gente muito nova que você vê tomando tiro, grávida que acontece alguma coisa, a gente tira como experiência. Nossa, eu tenho que tomar cuidado com isso, eu tenho que tomar cuidado com aquilo. E8

Ah, eu acho assim, que o trabalho aqui e vendo o sofrimento das pessoas, contribuiu assim, é como se te tornasse uma pessoa mais humana, mais humanizada com o sofrimento do outro. Porque mesmo a gente estando, digamos assim de fora, a gente não está ali com a família convivendo, mas a gente vê o sofrimento da família e do paciente e isso muda o seu modo de pensar e o seu modo de agir, pelo menos para mim foi assim. E14

Eu acredito que, infelizmente, o ser humano cresce no sofrimento. Então, eu fico vendo as pessoas sofrendo e a gente começa a desapegar das coisas. Esses dias a gente estava até conversando que a gente fica tão apegada a coisas materiais, a coisas bobas da vida que 
na hora que a gente vê que tudo isso pode acabar a gente começa a acordar, sabe?! Então, eu consigo me ver muito mais desapegada, a conseguir ter uma vida mais espiritual do que material. E isso quem me mostra são eles, são os pacientes. E16

Além disso, a vivência em um setor como o CTI, repleto de questões conflituosas, éticas e emocionais proporciona experiências pessoais que possibilitam o crescimento pessoal e profissional dos trabalhadores e conferem sentidos ao trabalho que realizam. A esse respeito, Morin (2001) atesta que, para que as organizações proponham mudanças no trabalho, devem projetar meios de valorizar o trabalho e dar-lhe sentido e, uma das formas, seria organizar as atividades voltadas para que o profissional teste suas capacidades, com objetivo de estimular o crescimento pessoal e o sentimento de responsabilidade.

Associado a todas as questões de ordem não econômica, o profissional de saúde, inserido no mundo globalizado e capitalista, visualiza o trabalho como fonte de renda, de independência financeira e sobrevivência. Portanto, outro aspecto que contribui na atribuição de sentido ao trabalho é a remuneração, a questão salarial. De acordo com Morin (2001), o salário oriundo do trabalho permite ao indivíduo prover suas necessidades básicas, proporciona um sentimento de segurança, além de possibilitar ao sujeito autonomia e independência.

Eu acho que motiva financeiramente. A gente precisa trabalhar, o dinheiro, mas tem ver os colegas, ver talvez a melhoria dos pacientes, satisfação pessoal de estar fazendo alguma coisa, entendeu? E8

Eu tenho vindo trabalhar mesmo porque eu preciso de trabalhar, eu preciso de dinheiro. Eu gosto, igual eu já te falei. Mas eu tenho as minhas realizações também pessoais e pra isso, eu preciso trabalhar. E9

Não vou negar, não é só a parte financeira, mas todo mundo que trabalha é porque tem objetivos na vida e pra conquistar os objetivos, infelizmente, o mundo é movido pelo dinheiro. Eu preciso trabalhar pra concluir meus objetivos. E18

Eu me sinto bem, eu gosto de cuidar. Contribui porque no final do mês eu tenho meu salário, que é uma contribuição que me favorece. Então, eu venho porque eu gosto, porque eu preciso trabalhar, porque é o meu sustento. E20

Através do trabalho eu consigo realizar os meus sonhos, entendeu?! Então meus sonhos são sempre realizados, com meu trabalho eu consigo tudo o que eu desejo, eu trabalho vou lá e compro. Então, eu me realizo financeiramente. Eu me realizo através do trabalho. E21 
Ele contribui pra independência, acho que tem também a independência financeira, que é sempre bom. E24

Entretanto, a motivação financeira ela não se mostrou exclusiva nos depoimentos dos sujeitos, estando vinculada a outras necessidades dos profissionais. Esses achados estão em consonância com o estudo realizado por Morin, Tonelli e Pliopas (2007) e por Oliveira e Piccinini (2005) os quais revelaram que em um trabalho com sentido a remuneração foi apontada como um fator complementar, sempre acompanhada de outro elemento. Desse modo, um trabalho que possui sentido para os profissionais da saúde não é apenas aquele que propicia benefícios financeiros, mas um conjunto de outros elementos associados à remuneração. Dessa forma, os gestores devem propiciar espaços de realização e prazer além dos alicerces econômicos explorando a dimensão subjetiva da organização (ARAÚJO; SACHUK, 2007).

Apesar de o salário não ser considerado um elemento central para conferir sentidos ao trabalho, quando ele não condiz com aquilo que o profissional busca e acredita ser o necessário ele se frustra e outras questões, principalmente, de reconhecimento voltam à tona e surge então, a desmotivação com relação ao trabalho.

Mas em relação ao salário e essas coisas deixa muito a desejar porque é uma profissão estressante $\mathrm{e}$, às vezes, a gente não tem reconhecimento, entendeu!? Salarial e nem do próprio paciente. E20

Quando você vê que não tem, por algum motivo, você vê que o seu trabalho não é valorizado com um salário que você acha que tem que ser. Isso também não é uma insatisfação só minha, de outras pessoas também e eu acho que isso é um sofrimento. E25

Hoje para te falar a verdade o que eu mais mudaria, mesmo que eu não tenha governabilidade, seria a remuneração. Você sabe que eu acho que, por exemplo, para trabalhar aqui no caso específico daqui do hospital, eu sou o médico horizontal, já tenho uma carga horária de 40 horas semanais que é uma carga horária considerável, eu gostaria de ser melhor remunerado, com perspectivas de futuro melhor, investimento, plano de carreira, essas coisas todas. E25

Eu mudaria, eu manteria talvez forma de trabalho eu acho que é a mesma, mas com uma remuneração melhorar para todos os profissionais de forma que pudesse ser uma dedicação exclusiva, por exemplo, que sua a carga de trabalho fosse só naquela instituição. E31

Outro aspecto da dimensão individual do sentido do trabalho foi a busca pela qualidade de vida por meio do trabalho, a qual também extrapola a remuneração. A qualidade 
de vida não foi considerada fruto do salário ou algo passível de ser adquirida, mas sim relacionada à tranquilidade de vida e ao equilíbrio entre o trabalho e a vida social. Isso revela a interferência do trabalho na vida pessoal do profissional.

Eu busco, eu acho que talvez, aquele equilíbrio entre o trabalho e vida pessoal, qualidade de vida fora trabalho, e o trabalho podendo me dar uma estrutura dessa vida pessoal também, né!? E a vida pessoal também me deixar estabilizado para o trabalho. Eu acho que trabalho e vida fora trabalho, entendeu? Porque eu não tenho perfil e não gostaria de viver para o trabalho e, também, não gostaria de ser um atoa, não trabalhar. Então, eu acho que esse equilíbrio ai. E25

No momento em que a qualidade de vida não é alcançada questões negativas do trabalho emergem no discurso dos sujeitos potencializando-as. A título de exemplo pode-se mencionar a carga horária de trabalho que reduz o tempo de convívio dos profissionais com suas famílias e amigos, a posição da profissão no mercado de trabalho e a remuneração.

Uma qualidade de vida que eu acho que eu ainda não tenho. A gente trabalha 36 horas, de segunda a sexta, dois plantões de final semana no mês e um feriado sim e um feriado não. E4

Meu trabalho tem um espaço muito grande e muito importante na minha vida. Ele ocupa, talvez $70 \%$ do meu tempo, da minha energia, da minha disposição. Mas, eu queria talvez que esse trabalho fosse menos importante, eu queria que fosse um trabalho como é para as outras pessoas, e eu tivesse uma vida pessoal e social mais ativa, mas ainda não consegui. E11

Eu queria era formar na minha faculdade, continuar me reciclando na minha profissão e ficar tranquila, ter meu lugarzinho, meu empreguinho, minha casinha, minha família e pronto, sabe?! Mas eu, às vezes, duvido que a enfermagem seja possível de me dar isso. E12

Sempre se dedicando demais ao emprego, à instituição, à vida de ser enfermeira e deixando de ser eu, de um contexto social, de uma vida toda para viver. Eu preciso melhorar muito isso, colocar a minha vida também em primeiro plano, porque chega a um ponto em que a gente não vai dar conta, vai adoecer. E15

Se a gente tivesse condição, ser mais bem remunerado, trabalhar menos, com certeza ia melhorar a minha qualidade de vida, de todos [...] uma dedicação que é um tempo grande, isso é cansativo, demanda muito, é estressante e com certeza isso também tem um ônus na diminuição do tempo de convívio com a minha família, pra minha vida pessoal, com certeza isso contribuiu negativamente. E31 
Portanto, um trabalho que possui sentido também precisa propiciar condições de vida social ativa e de qualidade. Ressalta-se que a qualidade de vida está indiretamente relacionada com a remuneração, sendo ela apenas um dos fatores. Morin e Gagné (2009) expõem que a falta de condições oferecidas pela organização faz com que o profissional adote posturas defensivas, ajustando seus valores e aspirações e, na maioria das vezes, realça a questão salarial.

O trabalho no mundo contemporâneo absorve as pessoas, e nos casos dos profissionais da saúde que atuam no CTI, de uma forma muito intensa, pois os cuidados são integrais, 24 horas por dia, todos os dias da semana. A escala de trabalho, como foi possível observar, muitas vezes, não se apresentava de forma completa e os profissionais presentes cobriam a falta de outros, sobrecarregando-os e ocupando um espaço que seria de descanso. Nesse aspecto, Araújo e Sachuk (2007) asseguram que o trabalho tornou-se impulsivo e incessante fazendo com que o tempo livre passasse a ser escasso ou quase inexistente, em alguns casos, passando a ser inclusive prolongamento do trabalho, "o trabalho apoderou-se de todas as esferas da vida e da existência humana" (p.64).

Portanto, a dimensão individual do sentido do trabalho permitiu refletir acerca da necessidade de se valorizar e (re)valorizar continuamente a dimensão subjetiva do trabalho na saúde. Reorganizar as estruturas das organizações e as políticas de gestão de pessoas com foco nos profissionais e em suas vidas profissional e pessoal, porque, como afirma Antunes (2011, p.10) "uma vida desprovida de sentido no trabalho é incompatível com uma vida cheia de sentido fora do trabalho".

\subsubsection{Os Sentidos do Trabalho - Dimensão Organizacional}

Figura 4 - Imagem oriunda da Técnica do Gibi, Belo Horizonte, 2013

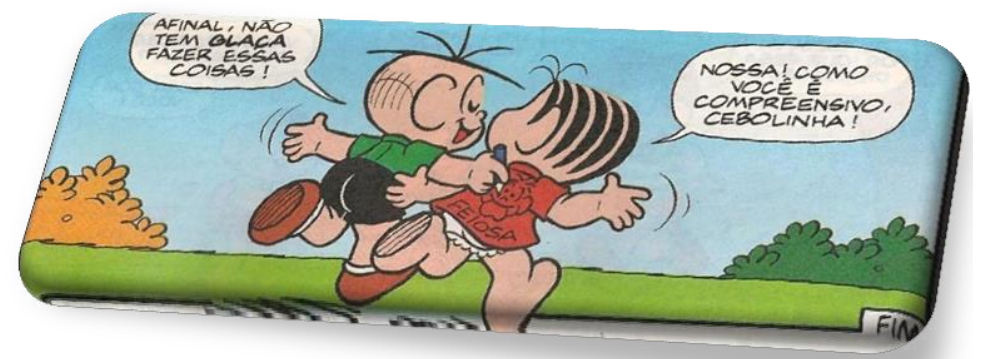

Eu acho que, o que me faz pensar é que unidos eu acho que a gente consegue fazer muitas coisas. E um trabalho que tem sentido eu acho que é aquele que com união a gente consegue melhorar o todo. E1 
O trabalho é estruturado nas organizações de forma a envolver os profissionais com seus serviços para que os objetivos organizacionais sejam alcançados. No caso das organizações de saúde, a estruturação do trabalho deve ser minuciosa visto que a procura pelos serviços é diferenciada e sua produção não gera um produto palpável, pelo contrário, ele é consumido em ato. Isto posto, Malta e Merhy (2003) ressaltam que o processo de trabalho em saúde, entre outros motivos, difere-se dos demais porque o usuário não se porta como um consumidor comum pois, ele não possui conhecimentos técnicos nem domínio daquilo que busca.

Dessa forma, o profissional da saúde precisa ter o comportamento diferenciado uma vez que está trabalhando com e para seres humanos em momentos de fragilidade, tendo, em algumas ocasiões, experiências negativas de saúde. O profissional deve se identificar com o trabalho que realiza e com a organização na qual atua, visto que isso será determinante na produção do cuidado e no alcance de objetivos e metas organizacionais. Para Erdmann et al (2004, p.467), “o cuidado está associado ao processo de viver e se materializa em relações complexas entre os seres e entre estes e o ambiente organizacional, institucional e natural". Urge nas instituições de saúde que os profissionais se liguem a elas por laços fortes para que o trabalho seja realizado de forma adequada.

A identificação com a organização proporciona benefícios, tanto para a organização quanto para os profissionais. Fernandes (2009) atenta para o conceito de identificação organizacional como um conjunto de aspectos, dentre os quais se destacam: a percepção do indivíduo de que seus valores e crenças são semelhantes aos da organização; o pertencimento entre as pessoas e a organização e; as crenças do indivíduo sobre a organização torna-se referência para sua auto definição. Já Pagés et al (1987), faz uma análise da identificação organizacional como um vínculo que o profissional estabelece com a organização por meio de laços de identificação, são eles: materiais/econômicos, afetivos, profissionais, ideológicos e/ou psicológicos de forma que ele volte sua tomada de decisão em função da instituição "vestindo a camisa da empresa". Morin (2002), por sua vez, afirma que os problemas de comportamento dos profissionais estão relacionados com a organização do trabalho, especificamente, com o "grau de correspondência entre as características das pessoas e as propriedades das atividades desempenhadas" (p. 72).

Tendo em vista as concepções de identificação organizacional apresentadas foi possível observar no presente estudo, baseado nas dimensões do sentido do trabalho de Morin, Tonelli e Pliopas (2007) e a literatura contemporânea acerca do tema, que a dimensão 
organizacional aproxima-se do conceito de identificação organizacional. A dimensão organizacional, adaptada para este estudo, englobou questões como o trabalho em equipe e os relacionamentos interpessoais; a identificação com a estrutura da organização e a dinâmica do setor; o comprometimento com a organização e suas metas e; o reconhecimento da instituição externamente. Dessa forma, o ambiente de trabalho é visto como estimulante fazendo com que os profissionais atribuam sentidos ao trabalho. Neste aspecto, Morin e Gagné (2009) afirmam que é uma forma de vincular os profissionais à organização e, também, quando percebem que a estrutura organizacional e do trabalho é articulada de forma positiva eles se encontram emocionalmente envolvidos com a instituição e, assim, encontram sentidos no trabalho.

O trabalho no CTI precisa envolver uma equipe multiprofissional, com trabalho coeso, com comunicação flexível e fluida, além do saber trabalhar com o outro, compartilhando conhecimentos e responsabilidades. Nesse aspecto, Pinho (2006) afirma que o trabalho multidisciplinar faz com que os profissionais da saúde reconheçam a necessidade da atuação conjunta e de diferentes contribuições para prestar um cuidado eficaz e de qualidade. Dessa forma, observou-se que os sujeitos percebem a necessidade do trabalho em equipe multiprofissional como um fator importante e determinante no cuidado ao paciente.

Não são todos os lugares que o psicólogo tem uma equipe tão diversa para trabalhar e eu acho que isso enriquece muito. E22

Eu acho que a gente tem um grupo muito bom de especialista, o grupo dos médicos, dos enfermeiros com uma experiência variada, mas que vem ao longo do tempo conseguindo um trabalho muito bom com a equipe de enfermagem, fisioterapia, fonoaudiólogas. Eu acho que o trabalho multiprofissional é bastante interessante. Eu tenho outros profissionais que vão trabalhar juntos em prol do paciente. [...] Interagir com outros profissionais é uma necessidade porque a gente não trabalha sozinho, é impossível. E31

Prestar um cuidado com excelência é o objetivo principal de uma organização de saúde. Para tanto, os profissionais devem atuar em equipe para alcançar os objetivos institucionais, atendendo às demandas dos clientes e baseados no bom relacionamento interpessoal visualizando as metas organizacionais (ALVES; MELLO, 2006). Uma equipe não se restringe a um grupo de pessoas atuando no mesmo ambiente, mas envolve, sobretudo questões relacionais, de comprometimento, confiança e objetivo comum. Dessa forma, os trabalhadores devem se voltar para o "modo-equipe" de trabalhar, que consiste no trabalho 
coletivo para o atendimento de uma pessoa/família/grupo de forma integral na construção de projetos terapêuticos (BRASIL, 2005).

O trabalho em equipe foi mencionado pelos sujeitos deste estudo de uma forma abrangente e em todas as suas possibilidades, contemplando desde o convívio responsável pelos relacionamentos sociais até como forma de dividir a responsabilidade pela conduta com o paciente crítico, conforme observado nos depoimentos:

Aqui a equipe é multidisciplinar né!? O pessoal da fisioterapia, da enfermagem, da nutrição, psicologia menos, mas também existe, a gente interage, discuti os casos [...] E a convivência com outros profissionais, trocas de ideias, de conhecimento [...] Você tem vários profissionais, você divide as responsabilidades. E25

É um grupo de médicos e interação com outros profissionais envolvidos, direcionado para a melhoria do atendimento, da qualidade do paciente, eu acho que isso a gente tem um grupo engajado, um grupo que quer isso. Eu acho que o ideal é uma interação entre os profissionais adequada. E31

Observou-se também, que o trabalho em equipe é um motivador, visto que um resultado positivo é fruto de um trabalho conjunto e compartilhado entre a equipe:

Então, o paciente chega aqui, você tem uma equipe abordando diferentes formas para o paciente poder sair do hospital tratado. E27

Eu acho que o trabalho ideal é com toda a equipe, independente da área tem que estar muito entrosada, tem que estar muito envolvida no sentido de que a gente não tá fazendo o bem pra gente. $O$ nosso paciente é o nosso cliente, então, às vezes, a gente passar por barreira pra tentar fazer o bem pro paciente né!? [...] A gente tem que tá entrosado sim, a equipe, não adianta falar que você consegue trabalhar sozinho. Isso é uma grande besteira, a gente precisa de todo mundo aqui, às vezes, eu estou no aperto e as meninas vem aqui e me ajudam. A equipe me motiva que me dar prazer trabalhar junto, isso tudo me estimula. E18

O que é mais importante é a relação que a gente cria com os profissionais tendo em vista o cliente, o paciente. Porque a gente sabendo como lidar, a assistência ao paciente fica muito mais completa, fica muito mais eficaz. Porque a gente conhecendo o paciente e a equipe a gente já sabe como que a gente vai chegar. E12

Ressaltando a questão do convívio, notou-se que ele se estabelece inicialmente no trabalho em equipe, configurando-se como relações profissionais, entretanto, passa a ser fonte 
de relacionamentos sociais visto que os profissionais despendem muitas horas no local de trabalho. Portanto, o trabalho deixa de ser uma esfera apenas racional na vida dos sujeitos e passa também a fazer parte da esfera emocional e sentimental gerado pela convivência com os colegas de trabalho. De acordo com Puente-Palacios, Vieira e Freire (2010), as relações afetivas favoráveis no ambiente organizacional influenciam de forma positiva a criação de vínculo afetivo com a equipe de trabalho. Dessa forma, permite que o profissional crie laços de amizades importantes para a vida social produzindo impacto benéfico também, na maneira como ele se relaciona e trabalha em equipe.

Durante a coleta de dados, percebeu-se que os profissionais tinham relações próximas e aproveitavam os espaços informais, como os corredores e as salas da coordenação, para interagirem abordando questões extraprofissionais e, até mesmo, se encontrando fora do ambiente de trabalho. Dessa forma, o relacionamento interpessoal se configura como um fator motivador para o trabalho e confere sentido a ele sendo também, parte da vida social.

A equipe do hospital, os meus colegas de trabalho, isso tudo é um motivador para eu vir aqui. A gente faz vínculo de amizade, amizade profissional também. E25

Mas tem ver os colegas [...] Não é aquele trem de ficar dentro de casa, igual eu ganhei neném, fiquei cinco meses em casa, gostei, mas eu estava doida querendo voltar a trabalhar, ver gente, conversar, entendeu? E8

E também sentiria falta, de uma parte, boa parte dos profissionais com os quais eu trabalho aqui, dos amigos que eu conquistei aqui. E31

As amizades que a gente faz aqui, porque, querendo ou não, a gente passa bastante tempo aqui. E32

O trabalho passa a ter sentido quando influencia positivamente a vida social do profissional reforçando a vinculação entre ambas. Desse modo, um trabalho com sentido é aquele que permite ao profissional vivenciar relações humanas gratificantes, o que implica em conhecer pessoas agradáveis e de qualidade e, assim, desenvolver laços de afeição (TOLFO; PICCININI, 2007).

No presente estudo observou-se que o relacionamento interpessoal não se realiza apenas entre os profissionais, mas também entre profissionais e pacientes. Embora, os profissionais procurem não se envolver com os pacientes e familiares, conforme observado: 
A gente vê paciente, a gente aprende a não se apegar ao paciente, a não levar pra casa os problemas daqui. Mas, não tem como porque estamos lidando com vidas né!? E20

A despeito da tentativa de não envolvimento com os pacientes, percebe-se que o envolvimento ocorre, o que pode estar relacionado ao tipo do cuidado prestado, haja vista o perfil do paciente crítico, com alto grau de dependência culminando com vivências de situações de vida e de morte.

Assim sendo, os profissionais, por vezes, possuem dúvidas e sentem medos de criarem vínculos com os pacientes em decorrência da possibilidade de sofrer com as situações de dor alheia, mas sem perceberem já sofrem por tentar manter afastado de si o outro (BRASIL, 2005). Logo, o que importa para os sujeitos é a motivação e o prazer relacionados ao contato com o ser humano, ao trabalho com pessoas, conferindo sentido àquilo que realizam, sendo uma peculiaridade do trabalho na saúde.

Lidar com o ser humano, é o que mais me motiva, é o que eu mais gosto de fazer [...] O que eu mais sentiria falta seria dos pacientes, porque eu gosto muito, eu gosto muito de lidar com eles. E17

Ah, eu sou muito apegada aos pacientes, eu sou. Eu acho que eu ia sentir falta do contato com o paciente, me faz bem o contato. E18

Aqui no CTI eu gosto muito do contato com paciente. Então, eu acho que CTI é um setor hospitalar que a gente encontra mais isso. E4

Percebe-se que o trabalho em saúde é alicerçado, entre outros aspectos, em diversas formas de relacionamento com o outro, seja com o paciente ou entre os profissionais, sendo considerado como motivador e prazeroso. A esse respeito, Morin (2001) aponta que um trabalho com sentido é aquele que permite experiências humanas satisfatórias, sendo uma forma de encontro com pessoas de qualidade, que possam realizar contatos francos, honestos e com quem é possível ter prazer em trabalhar e ajudar o outro a resolver problemas. Essa satisfação pode ser encontrada, tanto na associação com os próprios profissionais, quanto com os clientes.

Conseguir unir essa equipe de uma forma que a gente consiga pensar juntos as condutas a serem tomadas com os pacientes. E13

Acho que eu sentiria falta do carinho dos meus colegas de trabalho, dos pacientes que saíram bem e que foram embora. Eu ainda tenho 
muito contato com eles, porque eles saíram daqui e ainda lembram de mim. Eu sentiria falta dessa família que eu tenho aqui. E10

Face ao exposto, o sentido do trabalho em sua dimensão organizacional está relacionado com os laços de identificação proposto por Pagés et al (1987), neste caso com o laço afetivo expresso pelos relacionamentos interpessoais. Neste aspecto, Morin (2001, p. 17) afirma que,

$\mathrm{O}$ fato de estar em contato com os outros, de manter relações numerosas, e às vezes intensas, age como um verdadeiro estimulante para si mesmo, não somente para o desenvolvimento de sua identidade pessoal e social, mas também para o desenvolvimento de laços de afeição duráveis (MORIN, 2001, P.17).

O laço afetivo está associado principalmente, às relações sociais e afetivas encontradas no ambiente de trabalho. Para Pagés et al (1987), o vínculo criado entre o indivíduo e a organização se opera na esfera dos afetos, ou seja, por meio da dominação psíquica. A identificação proposta por esses autores está associada ao poder da organização em dominar o profissional, de forma inconsciente, a manter o vínculo com a mesma. Neste estudo, percebese essa ligação por meio dos laços afetivos com a equipe de trabalho:

Mas, tem uma questão assim também, o que me motiva a continuar fazendo é pessoal. Eu, historicamente, sou muito relacionado a esse grupo, minha história pessoal, entendeu!? Tanto é que eu pensei em sair como outras pessoas pensaram, mas eu tenho dificuldade de dar esse passo por conta da história. E28

Nessa perspectiva, Pinho (2006) afirma que o trabalho em equipe de saúde remete ao acolhimento do outro resgatando a subjetividade dos indivíduos. No CTI, observou-se o resgate do sujeito profissional e do paciente, tornando a relação mais complexa e produtora de sentidos e de realização pessoal e profissional. A equipe "é um tecido de relações: presentes e passadas, de poderes e saberes, de classes sociais, de afetos... Relações entre diferentes trabalhadores, permeadas pelas relações entre os trabalhadores e usuários" (BRASIL, 2005, p. 99).

O trabalho em equipe de saúde, portanto, é uma fusão daquilo que se considera, convencionalmente acerca do trabalho em equipe sendo uma forma de atuação coletiva, além das particularidades do trabalho em equipe em saúde. Nesse sentido, Pinho (2006) afirma que, tradicionalmente, identifica-se no trabalho em equipe, o desempenho, a responsabilidade e a tomada de decisão feita coletivamente, além do uso de habilidades e conhecimentos complementares. Entretanto, além dessas características, o trabalho em equipe de saúde é 
permeado por situações específicas do setor que impactam nas relações de trabalho como, por exemplo, o predomínio de um discurso sobre o outro e a falta de confiança entre as categorias profissionais resultante de assimetrias nas relações de poder entre profissionais de categorias distintas.

O trabalho na saúde é caracterizado pela atuação de uma variedade de profissionais, com paradigmas, interesses, experiências pessoais e profissionais diferentes que configuram maneiras diversificadas de enxergar e prestar cuidado ao paciente (SCHERER; PIRES, 2009). A prática do cuidado possui uma divisão de tarefas por categorias que guiam o trabalho e os saberes, como afirma Ayres (2004) que são aplicados pelos profissionais e, assim produz-se saúde. Logo, diferentes profissionais mobilizam saberes distintos que, de acordo com Souza e Scorsolini-Comin (2011), produzem discursos marcados por disputas de saberes, pois a posição do profissional é de alguém que possui um conhecimento que foi obtido, certificado e legitimado ao longo do tempo.

Desse modo, a constituição da profissão e as relações de poder construídas são determinadas historicamente. A esse respeito, Scherer, Pires e Schwartz (2009, p.723) afirmam que "o trabalho em saúde é marcado pela historia das profissões que obtiveram uma definição do seu domínio de competências e atos próprios que pesam sobre a divisão do trabalho e sobre a fronteira entre os grupos". De acordo com Merhy e Franco (2003), historicamente a formação do modelo assistencial para a saúde, centrado nas tecnologias duras e leve-duras, a partir dos interesses econômicos, fez com a organização da micropolítica do trabalho em saúde fosse voltado para a consulta médica, "onde o saber médico estrutura o trabalho de outros profissionais" (p. 318).

Com base no exposto, os depoimentos dos sujeitos dessa pesquisa revelaram que o maior conflito no trabalho dessa equipe do CTI está relacionado ao poder que o médico exerce sobre profissionais de outras categorias.

Então, isso seria uma das coisas que eu mudaria, o fortalecimento da equipe, trazendo os enfermeiros, os fisioterapeutas e fazendo uma discussão junto com a equipe médica porque eles fazem corrida de plantão todos os dias e a gente não é inserido nessa corrida de plantão, a gente escuta, mas a gente não é questionado, não faz parte, entendeu? No final das contas a gente percebe que é só mais um no contexto, que a gente não influência muito nas condutas que vão ser tomadas com o paciente. Então, eu acho que isso para mim é bem desfavorável, me faz pensar mais de continuar. E13

Tem plantonista (médico) que você consegue discutir o caso do paciente, mas tem alguns que não adianta você falar. Então, isso te dá 
uma tristeza, te dá uma falta de ânimo mesmo de continuar. Isso que eu acho que é o pior aqui. E14

A relação multiprofissional. Ela hoje acontece de forma hierárquica. Então, o enfermeiro que respeita o médico, o fisioterapeuta que respeita o médico, mas o médico não respeita o fisioterapeuta, não respeita o enfermeiro, o enfermeiro não respeita o fisioterapeuta e ai vai. Hoje é a hierarquia, quem tem maior poder é respeitado, mas os de baixo não. É o médico no topo e o enfermeiro e o fisioterapeuta nas bases, talvez os fisioterapeutas um pouquinho abaixo ainda da enfermagem. A enfermagem que eu falo de nível superior porque os técnicos eles são mais baixos ainda. Mas, eu mudaria isso, porque não há distinção, todos aqui desenvolvem atividades diferentes em prol do bem comum. E29

Os depoimentos apontaram que as práticas médico-hegemônicas ainda se sobressaem no setor saúde. No caso do CTI, onde as relações se apresentam acentuadas e próximas, com forte contato interpessoal predominando o poder da categoria médica, que se traduz como desmotivador para os profissionais das demais categorias. O profissional que enfoca a atitude individual, não diferenciando o que está no seu limite do fazer e o que depende da atuação do outro, pode se tornar impotente ao agir, além de vivenciar sofrimento e descrença na construção da prática integrada (SCHERER; PIRES, 2009). Assim, o trabalho na saúde deve acontecer de forma coletiva, visto que "não há trabalhador de saúde que dê conta sozinho do mundo das necessidades de saúde, o objeto real do trabalho em saúde" (MERHY; FRANCO, 2008, p.431).

Os profissionais são diferentes e possuem saberes e perfis diversificados o que influencia no seu modo de fazer. Todavia, para que os conflitos entre as categorias profissionais sejam atenuados é importante que cada categoria tenha clareza da delimitação do seu trabalho e, dessa forma, realize sua prática a fim de contribuir com a equipe profissional e para a prática do outro. OS depoimentos dos sujeitos apontaram para a necessidade da delimitação das funções na equipe:

Acho que seria a questão de delimitação o que é de quem. Talvez seria mais fácil realmente você ser fisioterapeuta. Muitas vezes, a gente faz o papel que não precisa, que todo mundo faz. E3

E lá assim, você era realmente o supervisor. Tem fazer isso, isso e pronto, estas são as funções. Tem as funções dos enfermeiros e tem as funções dos técnicos. E aqui eu não consigo ver essa divisão. A linha é muito tênue entre o que eu faço e o que eles fazem. E5 
Questão da gente não saber a diferença entre o nosso trabalho e o trabalho do técnico. Então, é muito difícil, pelo menos para mim, estipular determinados limites o que é a minha parte e o que a parte do técnico, entendeu? E13

Nessa perspectiva, o trabalho em equipe deve ser estimulado considerando que os maiores avanços científicos foram alcançados coletivamente. Para que o trabalho em equipe ocorra de forma efetiva é necessário que cada membro se oriente em sua área de competência atuando de forma integral no CTI (SAFAR; GRENVIK, 2012).

Ainda no que concerne à dimensão organizacional, os sujeitos da pesquisa mencionaram características do trabalho que contribuem para que o mesmo tenha sentido, entre elas destacam-se: a estrutura, a política organizacional, a dinâmica do setor e o comprometimento com a organização.

Do que eu mais sentiria falta eu acho que da estrutura. Da estrutura de você ter o que você precisa. Então, assim se eu preciso de um remédio eu tenho! Se eu preciso a enfermagem esta sempre do meu lado, fisioterapia. Então, eu acho que a estrutura do CTI como um todo ela é muito boa. E24

O trabalho no CTI é dinâmico, é imediato, é agudo e é um desafio também, não é fácil, mas engloba vários sistemas, vários profissionais. E31

As características mencionadas relacionam-se com os laços ideológicos expostos por Pagés et al (1987), os quais se referem à esfera das representações, valores e princípios organizacionais para os profissionais no que concerne ao ambiente organizacional e sua vida pessoal. O laço ideológico reflete a importância da organização do trabalho, de uma forma geral, para que a identificação aconteça, associando-se ao sentido do trabalho, uma vez que, como afirmam Tolfo e Piccinini (2007), é necessário que as condições de trabalho sejam adequadas e, assim proporcionem um ambiente favorável para que o profissional atue e encontre sentido no trabalho.

Os sujeitos deste estudo apontaram para a importância da estrutura e a organização da instituição e do próprio setor para que o profissional desenvolva sua prática de forma segura e coerente com suas crenças:

Acho que é muito gratificante, é aonde que eu sinto que faz a diferença. Sem contar que eu tenho mais recurso então, isso me dá mais segurança para trabalhar. E11 
Eu gosto de CTI porque são poucos pacientes que a gente fica para poder dar assistência, então isso te faz ter um conhecimento maior, você consegue realizar seu trabalho com segurança. Eu já tive experiência com 30, 40 pacientes, e aí é frustrante quando você só passa pelo leito do paciente, você não consegue planejar nada, um cuidado para ele, você não consegue dar uma assistência de qualidade. E no CTI você tem essa oportunidade. E14

A segurança é conferida também pela disponibilidade de recursos e serviços e pela disposição dos leitos e materiais para que os profissionais tenham fácil acesso tanto aos pacientes quanto aos recursos necessários para prestar uma assistência imediata e de qualidade:

Eu gosto do ambiente que você vê que o paciente está reestabelecendo, que você tem proximidade, que você está num lugar com vários próximos e que seu acesso a eles é fácil quando eles precisam, entendeu? Que, às vezes, o que você for fazer com o paciente de técnica você tem que estar muito próximo porque já está tudo alocado tudo dentro desse setor, o acesso se você precisar, se um paciente precisar de ventilação, já está tudo perto, o ventilador está ali você pega, o atendimento fica agilizado. E18

Primeiro ter uma infraestrutura adequada, ter materiais adequados, médicos bons, uma equipe de enfermagem excelente, sempre ter qualquer exame, alguma coisa de diagnóstico mais rápido. Então, seria o CTI ideal. E15

Os profissionais ressaltaram, ainda, a imprevisibilidade do trabalho no CTI sendo então, necessária a sistematização das rotinas e o planejamento:

Escolheria o CTI porque eu acho que você pode programar a sua vida, mesmo que tenha várias intercorrências, mesmo que depende tudo de você dá pra programar e organizar. Dá pra você fazer um trabalho bom. E23

Eu gosto muito de trabalhar no CTI por ter qualidades que são muito afins comigo porque eu gosto de lugares organizados, que eu possa ver como as coisas realmente funcionam, não tem as barreiras que tem no pronto socorro, por exemplo, falta de vaga. Então, é um setor que não tem como você enfiar mais gente além da capacidade dele que são 30. E13

Além disso, os sujeitos citaram que as condições trabalhistas determinadas pelo contrato com a instituição os motivam a permanecerem na instituição e a se esforçarem para 
prestar um serviço de qualidade no sentido "recompensar" a organizar pelos benefícios empregatícios disponibilizados:

O que eu tenho aqui hoje nenhum outro hospital me fornece que é uma carga horária definida, carteira assinada, a segurança de trabalho e na fisioterapia hoje isso é muito raro. E16

Além da relevância que a estrutura da instituição tem para os profissionais, os sujeitos também consideram importante ter o perfil compatível com a dinâmica do CTI fortalecendo os laços ideológicos, haja vista que o profissional percebe a compatibilidade dos seus desejos e vontades com o que o setor oferece:

Olha, se eu for levar em consideração só o hospital, o lugar físico eu vou sentir falta do perfil do paciente e da correria, porque eu sou muito agitada. E12

Eu acho porque é muito intenso. A demanda do paciente é muito intensa, a resposta é muito intensa e isso é uma coisa que eu acho que me atraiu durante a formação médica. E28

Sempre tive gosto pela emergência e um perfil de. E eu acho que até de postura, de tranquilidade de agir no momento que você tem que agir rápido, seu raciocínio rápido, a fisiopatologia das doenças e do perfil de ajudar um doente que necessita de uma atuação imediata [...]. E31

A identificação organizacional é um processo realizado por meio de mediações nas quais a organização consegue aliar suas restrições (sejam elas internas ou externas) aos objetivos do indivíduo por meio dos laços de identificação que foram citados anteriormente. Ressalta-se a importância da compatibilidade entre o perfil do profissional com o perfil demandado para a atuação no CTI, pois, caso contrário, a mediação não acontece e o profissional não se identifica com a organização. No caso dos laços ideológicos, a organização oferece insumos estruturais (políticas, estrutura física, condições de trabalho adequadas e outros) que fazem com que o profissional se sinta satisfeito em um processo de representação fazendo com que, psicologicamente, ele seja capaz de conviver com os sentimentos dúbios pela organização, entre restrições organização e privilégios que ela oferece (PAGÉS et al, 1987).

Observou-se nos depoimentos que os profissionais se ligam à instituição e atribuem sentido ao trabalho devido à adequada estrutura e organização do trabalho. Apesar disso, eles reconhecem algumas falhas na organização que lhes proporcionam sofrimento e 
desmotivação. Entretanto, os profissionais não são capazes de se desvincularem dela, pois os laços de identificação produzem "um reforço circular entre a angústia e o prazer que assegura a manutenção de um sistema psicológico semelhante às estruturas da organização" (PAGÉS et $a l, 1987$, p. 29). Os profissionais suportam os aspectos negativos da organização e do trabalho porque estão envolvidos pelo processo de identificação. As falhas mencionadas pelos profissionais estão relacionadas à sobrecarga de trabalho, à falta de recursos humanos adequados para uma assistência de qualidade, à carga horária extensa para um ambiente estressante e aos problemas de infraestrutura:

Apesar de ser só três pacientes a carga de serviço é muito grande. Então, a gente acaba que fica muito técnico, muito repetitivo, só apagando fogo, apagando incêndio e resolvendo problema aqui e problema ali. Ainda com isso tudo tentando prestar um cuidado de qualidade e, algumas vezes, fica prejudicado por que tem vez que a escala é reduzida, o pessoal falta, o funcionário que está com você está insatisfeito. Aí isso tudo acaba atrapalhando o serviço. E5

Talvez ter mais profissionais para gente conseguir dar uma assistência maior aos pacientes. Falta mais médicos, mais enfermeiro. E27

A única coisa que tem que ser redefinido é a carga horária. Porque como eu tenho que fazer um final de semana por mês então, acaba que eu trabalho doze dias ininterruptos [...] Então, é uma estratégia nostop. Para o paciente, para o acompanhamento horizontalizado dele é ótimo. Mas, para o profissional não é legal. Então, isso é uma dinâmica que precisa ser melhorada, isso não é bom. Isso cansa, se você não tiver um prazer muito grande no que você faz, você não faz. E6

A nossa infraestrutura não é boa, então assim, é incômodo, pelo menos para mim, chegar no CTI e ver cada biombo daqueles separando os pacientes. Primeiro que eu acho que eles ficam sem privacidade, não é uma coisa bonita de se ver. E15

A gente tá vivendo agora um momento de desorganização por falta de médicos, entendeu!? Geralmente a gente olhava 6 pacientes o que tem variado agora é que a gente tem olhando muito mais pacientes de uma maneira mais aleatória, porque os horários estão indefinidos. E28

Eu acho que a carga horária de trabalho é bastante alta, sem dúvidas, para um ambiente assim, muito barulho. Mas, é prazeroso. E31

Conforme observado nos depoimentos, os profissionais reconhecem os problemas da organização, mas estão ligados a ela de uma forma consistente. O vínculo estabelecido faz com que as contradições organizacionais fiquem no inconsciente do indivíduo e se encontrem 
transformadas pelos estímulos positivos oferecidos pela organização fazendo com que consiga conviver com as contradições e não se volte contra a organização. Portanto, a introjeção das contradições passa a recalcar os desejos dos profissionais, pois a organização oferece condições boas para ele conviver com elas sob a forma de um ideal (PAGÉS et al, 1987). Assim, os sujeitos convivem com a situação que a organização oferece, mas, ao mesmo tempo, conseguem identificar um ideal de trabalho a ser desenvolvido na e pela instituição:

O trabalho ideal seria... As questões da própria estrutura física e de, por exemplo, aqui no hospital a gente não tem um serviço de hemodinâmica que, muitos casos chegam aqui e, talvez fossem resolvidos mais rapidamente e geraria menos sofrimento e menos custos se aqui no hospital tivesse serviço de hemodinâmica. Então assim, no hospital como eu trabalho no CTI, então se você tiver a mão todo o recurso humano, toda a tecnologia, toda a infraestrutura para $\mathrm{o}$ serviço de CTI acontecer seria o ideal e ainda com carga horária que me permita me dedicar exclusivamente ao hospital, eu acho que isso seria o ideal. E25

Neste processo, observa-se também, a implicação da identificação do profissional com a instituição e seus objetivos. O profissional que se identifica com os objetivos do trabalho não envida esforços para alcançá-los o que contribui para a organização, para a recuperação do paciente e para o próprio profissional:

Eu acho que dentro de um todo, do contexto que eu desempenho minhas funções adequadamente e a pessoa que está do meu lado desempenhando as mesmas funções adequadamente a gente consegue prestar uma melhor assistência para os pacientes que estão aqui, disponibilizar vaga mais rápido. Então, fazer o hospital movimentar mesmo. E13

Eu acho que é prestar uma assistência de uma complexidade muito alta para um paciente fragilizado, que precisa totalmente do seu cuidado. Então, é se doar completamente. E15

Cumpre o objetivo do hospital que é cuidar do paciente né!? Então, quando a gente cuida o hospital fica resguardado no sentido da família, de que está sendo feito pra melhorar, na evolução do paciente. E18

Fazendo a minha função aqui, eu sou o médico horizontal intensivista, eles me contratam pra isso e eu tento fazer esse papel. Eles precisam desse profissional, eu sou o profissional e tento fazer o serviço desse profissional. E25 
Um trabalho que tem sentido é associado à adequada organização das tarefas e atividades, como expõe Morin (2002), uma vez que isso leva à eficiência dos resultados esperados. Todavia, as tarefas e atividades precisam ser claras e valorizadas pelos profissionais. Os depoimentos apontaram que os profissionais possuem a percepção do trabalho que deve ser realizado, considerando que os objetivos são claros e permite a direção das condutas em prol deles.

Para cumprir os objetivos e contribuir com a organização, o profissional passa a se comprometer com a mesma modificando comportamentos e adotando atitudes exemplares mediante as regras e normas institucionais. A esse respeito, Morin e Gagné (2009) destacam que o comprometimento organizacional está relacionado à estabilidade pessoal (baixos atritos entre pessoas), assiduidade (baixo absenteísmo), o desempenho no trabalho e a qualidade dos serviços prestados. Pode-se notar que os depoimentos dos sujeitos corroboram aos achados de Morin e Gagné (2009):

Nunca cheguei atrasado, nunca faltei [...] nunca dei nenhum motivo para chamar minha atenção, sempre fiz meu trabalho com qualidade, umas vezes, não concordando com a postura de alguns profissionais, mas a minha parte eu sempre fiz, nunca deixei a desejar, nunca saí daqui com a consciência pesada [...] Eu acho que isso é fundamental e falta muito de alguns profissionais, o compromisso. Se não quer ter compromisso com a coordenação tenha compromisso com o paciente, com o familiar, com o colega. E5

Eu acho que contribui se eu seguir as normas direitinho. Entrada, saída, meus horários. Eu procurar não faltar. Nisso eu sou disciplinada. E10

Eu acho que é mais o sentido da responsabilidade e do compromisso que eu assumi com a instituição. Então, isso que me motiva a vim trabalhar. E13

O comportamento adequado é considerado consequência do grau de comprometimento que o profissional possui com a organização. De acordo com Morin e Gagné (2009), o compromisso com a organização reflete a natureza da relação entre o profissional e o trabalho sendo um importante critério de eficácia organizacional, afetando o comportamento do profissional no âmbito da instituição. A esse respeito, Simon e Coltre (2012) ressaltam que o comprometimento organizacional pode ser analisado por três dimensões: a afetiva, a instrumental e a normativa. Analisando os depoimentos acima se percebe a presença do 
comprometimento normativo, o qual está associado à lealdade e o sentimento de compromisso do profissional com a organização, refletindo o alto nível de comprometimento do indivíduo com a mesma (SIMON; COLTRE, 2012).

O comprometimento que o profissional estabelece com a organização está associado ao laço psicológico uma vez que se relaciona aos sentimentos e à estrutura psicológica. Segundo Pagés et al (1987), o profissional é capaz de ter relações dúbias com a organização, mas ele as absorve e as transforma em condutas articuladas e moldadas às políticas organizacionais. Contudo, no presente estudo, o comprometimento organizacional sofre prejuízo e provoca sofrimento nos profissionais quando os coordenadores são considerados inflexíveis e adotam posturas não participativas, como se pode observar:

O sofrimento pra vários daqui é que a coordenação segue uma linha dela. Privilegia uns e outros não. Então, isso causa sofrimento em vários profissionais aqui. E4

A questão tipo assim, de você pedir alguma coisa e nunca dá para poder fazer. Isso daí chateia a gente sabe?! Tem coisa que não dá. E7

Mais flexibilidade, mais compreensão que a gente não está tendo, mais tolerância que a gente também não está tendo [...] Alguma coisa pessoal assim mesmo, igual eu trabalho muito bem, tem tantos anos que eu trabalho aqui, é funcionária exemplar só que o dia que eu preciso de uma coisa pra mim elas não olham isso. "Ah, não dá pra te dar". Ela simplesmente não dá. E9

A questão da gestão também. A gestão ela podia ser mais flexível. E12

Os profissionais não se sentem valorizados pelos gestores, os quais não percebem seu esforço além de não promovem o bem-estar individual de cada profissional. Os gestores precisam ter coragem para adotar estratégias que visem o bem estar dos profissionais com justiça e equidade. Além de reconhecer os méritos dos funcionários por suas atitudes e comportamentos (MORIN; GAGNÉ, 2009).

Os gestores são considerados peças chaves no funcionamento do setor e, principalmente, na condução da equipe de trabalho. Neste aspecto, a complexidade das atividades que o gestor desenvolve demonstra a sua importância como agente de mudança uma vez que são essenciais na articulação entre serviços e pessoas. Portanto, a condução da gestão deve levar em conta tanto o desejo dos profissionais quanto da organização para criar sintonia entre eles e o trabalho ser coerente para ambos (BRITO; MONTENEGRO; ALVES, 
2010). Os gestores devem ser capazes de organizar os estímulos como reforços na atribuição de sentidos ao trabalho. Desse modo, Morin e Gagné (2009) afirmam que o valor do líder está em manter e promover valores fundamentais que aumentem o valor do trabalho e, consequentemente, auxiliem na atribuição de sentido ao trabalho.

Os resultados desse comprometimento com as normas e metas organizacionais e o cumprimento dos objetivos do trabalho faz com que a instituição se beneficie com a redução de custos e também com o reconhecimento externo, conforme evidenciado pelos sujeitos:

Então, se o paciente tiver um cuidado bom, ele vai receber alta logo e a instituição vai ter seu reconhecimento. Automaticamente eu estou ajudando a instituição. E20

A equipe de psicologia ela tem um contato com a rede que tem crescido muito. A gente constrói parcerias muito sólidas. Cada paciente que tem alta a gente não deixa sair daqui sem encaminhamento. Então, dependendo da gravidade ele já sai daqui direto para o lugar. E como a rede é também pública e tem todos os problemas que aqui tem. Então, às vezes, a gente tem que negociar, discutir, entender pra conseguir encaminhar o paciente. Quando a gente faz isso, vai mostrando o nosso trabalho também, o trabalho que vai acontecendo dentro do hospital [...] Então, eu acho que hoje o (hospital) é visto como um polo receptor de pacientes psiquiátricos. Não é só pra mandar pra rede, é que trata também, sabe?! E22

Contribui até em uma economia porque desde o momento que a nutrição, a gente começa a atender no inicinho o paciente evitando à desnutrição a gente vai evitar um monte de complicações que ele possa ter aqui. Porque aí vai até diminuir custos. E1

Uma vez que o paciente é reabilitado, recuperado mais rápido, mais rápido ele vai ter alta do CTI. Mais rápido da instituição, menos gastos, menos demanda. Nesse sentido mesmo de fluxo. E3

O meu trabalho reduz o custo de vários outros adjutores consequentes da internação do paciente no hospital. Por exemplo, antibiótico, equipamento de forma geral, a diária do paciente no CTI, tudo isso influencia de uma certa forma. Talvez não tão notório quanto você pegar e contar, mas sim de uma forma geral, no todo. E29

Percebe-se a importância de apontar os laços de identificação que os profissionais da saúde possuem com a organização. A identificação modifica condutas e faz com que o indivíduo atue com prazer, comprometimento e ética, pois as atividades que ele executa possuem sentido além de serem consoante com seus valores e princípios. A pessoa que percebe o trabalho de forma significativa tende a ter bem estar físico e mental refletindo em 
seu comportamento e atitudes. Portanto, é assídua, cumpre seus horários, minimiza os erros e acidentes, trabalha em equipe para alcançar os objetivos organizacionais e possui uma ligação emocional com o trabalho (MORIN; GAGNÉ, 2009).

$\mathrm{Na}$ dimensão organizacional do sentido do trabalho foi possível assinalar os seguintes laços de identificação mencionados por Pagés et al (1987): laços afetivos, evidenciados nos relacionamentos interpessoais que os profissionais estabelecem, tanto no trabalho em equipe, quanto socialmente; laços ideológicos na representação que o setor possui para os profissionais no que diz respeito à estrutura, condução das atividades e políticas e; laços psicológicos relacionados ao comprometimento organizacional visto que esse demonstra que o profissional está realmente ligado à organização. Outro laço que foi identificado foi o laço material e econômico observado na dimensão individual do trabalho quando os profissionais citam o trabalho como fonte de sobrevivência e independência financeira.

Dessa forma, a dimensão organizacional do sentido do trabalho propicia a reflexão de como a estrutura da organização e de um setor influenciam no modo como o profissional atribui sentido ao seu trabalho, bem como interfere na conduta profissional. Dessa forma, Morin, Tonelli e Pliopas (2007) afirmam que o profissional precisa crescer dentro da organização, em escalas hierárquicas e, principalmente, na mobilização de competências, habilidades e conhecimentos que permitem que ele se desenvolva. Contudo, não basta seu aprimoramento, os profissionais também precisam visualizar os sentidos no trabalho, a valorização por parte dos gestores e perceberem que o trabalho permite o reconhecimento da instituição, além de estarem atuando em atividades que são consonantes com seus princípios.

As tramas que a identificação organizacional possibilita ao indivíduo e à organização corroboram com a afirmação de Morin e Gagné (2009), segunda a qual o profissional consegue realizar um trabalho que faz sentido em um ambiente que não faz ou realizar um trabalho sem sentido em um ambiente que o possui. Contudo, o ideal seria realizar um trabalho que conjugasse as situações apresentadas. A organização precisa, portanto, se estruturar e proporcionar ao profissional de saúde um ambiente favorável e passível de ter sentidos haja vista a necessidade de conciliação dos interesses das organizações, dos profissionais e dos usuários. 


\subsubsection{Os Sentidos do Trabalho - Dimensão Social}

Figura 5 - Imagem oriunda da técnica do Gibi, Belo Horizonte, 2013

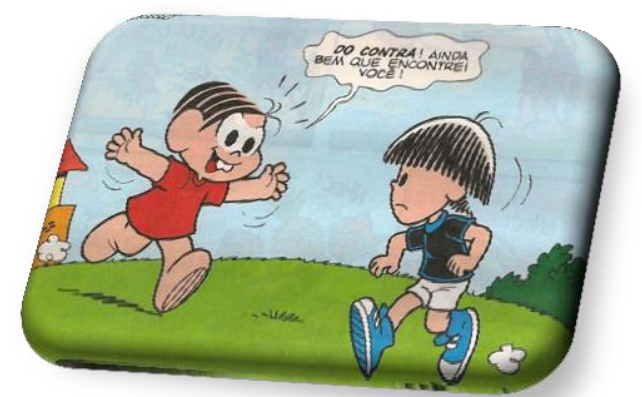

Trabalho que tem sentido... $O$ bem querer. Toda pessoa da área da saúde é altruísta. Se não ela não pode exercer, porque é um cuidar né!? E cuidar é sinônimo de amar só que do ponto de vista prático. E6

Fonte: Dados coletados para fins deste estudo.

Na dimensão social do sentido do trabalho foi analisada a contribuição do trabalho para a sociedade. Uma das condições para que o profissional encontre sentido no trabalho é perceber a utilidade do trabalho para a sociedade assim como suas consequências sociais. Morin (2002) afirma que para que um trabalho tenha sentido ele deve contribuir socialmente, isto é, "deve permitir a união entre o exercício de atividades e suas consequências sociais. Isso contribui à construção da identidade social e protege a dignidade pessoal. Esse âmbito do trabalho reconhece o prazer de contribuir para a sociedade" (MORIN, 2002, p. 73).

Foi possível identificar pelos depoimentos dos entrevistados que eles percebem a contribuição social do trabalho em sua prática cotidiana, dentre as quais se destacam: ajudar a quem precisa; acolhero paciente e seu familiar; trabalhar em hospital público; auxiliar na retomada da qualidade de vida dos indivíduos e; permitir que a sociedade se sinta segura por ter um serviço de qualidade. Com relação a ajudar quem precisa, os profissionais citaram que é motivador ajudar o próximo, sendo uma característica inerente às pessoas que atuam na área da saúde, proporcionando realização e satisfação. Eles consideram essa ajuda como fazer o bem para o outro e "se doar" favorecendo o bem estar do próximo:

Eu acho que é ajudar mesmo o próximo. Levar para ele um pouco de conforto. E1

A motivação é saber que eu vou estar ajudando uma pessoa, é o principal né!? A gente coloca como se fosse alguém da família da gente né!? E a gente poder ajudar. E7 
$\mathrm{Eu}$ acho que todo pessoal da área médica é um pessoal de bem quer, sabe?! Então, o sentimento sempre é esse mesmo de querer o bem ao próximo né!? E6

Uma satisfação de poder está ajudando um paciente ou familiar nesse momento de dificuldade que eles estão passando. Talvez assim, uma satisfação de poder ajudar quem está precisando. E16

A minha função é ajudar o próximo. Isso é fundamental na sociedade, né!? E30

O momento de estar trocando energia com o paciente enfermo, de você estar se doando pra alguém, isso é uma coisa que eu sentira falta. E27

Observou-se que os depoimentos fugiram do modelo prescritivo de trabalho em que o profissional se preocupa com o cumprimento de metas e normas e se voltaram para o atendimento ao ser humano e à sociedade. Entretanto, o trabalho em saúde é realizado com e para seres humanos, condição que facilita a expressão do trabalho focado nas pessoas. Desse modo, é fundamental que o profissional reconheça tal condição para que atribua sentidos ao trabalho. Esse resultado está em consonância com o estudo de Morin, Tonelli e Pliopas (2007) no qual os sujeitos relataram que um trabalho que tem sentido precisa contribuir para a sociedade.

A contribuição social do trabalho, identificada na fala dos sujeitos, demonstra que o trabalho realizado pelos profissionais de saúde no CTI é compatível com seus valores e princípios, sendo fundamental desenvolver um trabalho que propicie o bem do outro. Morin (2001) assevera que o trabalho é uma atividade que está inserida na sociedade e ele deve respeitar os modos de saber e viver em sociedade tanto na busca pelos objetivos, quando nas relações estabelecidas.

Dessa forma, o trabalho em saúde no CTI ultrapassa a ajuda ao próximo devido ao perfil crítico do paciente que se encontra neste setor. O profissional do CTI precisa estar preparado para atuar em um ambiente permeado por um aparato tecnológico de ponta e por situações de estresse relacionais além de conviver diariamente com o sofrimento de pacientes e familiares. Lucena e Grossetti (2004) afirmam que a complexidade do cuidado no CTI, devido ao aprimoramento dos recursos utilizados, exige dos profissionais, atenção no desempenho técnico e científico e, principalmente, percepção do indivíduo que cuida e é cuidado. Desse modo, faz-se necessário a conciliação de tecnologias duras, leve-duras e leves 
por parte dos profissionais com vistas a amparar e lidar da melhor forma possível com o sofrimento do paciente e atender a reais necessidades dele.

Conforme Merhy e Franco (1997) expõem, o agir do trabalhador da saúde oscila entre a proposta de organização do cuidado (dimensão prescritiva do trabalho) e a condição de trabalhar com a subjetividade que opera entre ele e os usuários (dimensão subjetiva do trabalho), isto é, transita entre uma esfera burocrática e uma do cuidado acolhedor no qual são estabelecidos vínculos. Ainda de acordo com esses autores, a micropolítica do processo de cuidar em saúde significa se envolver com processos de subjetivação, com a dimensão humana dos atores envolvidos. O trabalho na saúde não pode se desvencilhar do cuidado acolhedor, pois é um polo do trabalho cujo objeto é o ser humano. As relações de trabalho implicam em um encontro entre o usuário e o profissional sendo produtor de cuidado, de subjetividade e transformação.

Visto o exposto, os sujeitos da pesquisa consideraram o acolhimento ao paciente e familiar como forma de contribuir para a sociedade. $\mathrm{O}$ acolhimento aqui citado não é entendido como um serviço prestado, mas como um modo de ser e agir em saúde, modos de saber e fazer na prática do cuidado ao paciente e sua família. A análise dos depoimentos permitiu inferir que o acolhimento referido pelos profissionais se relaciona a cuidar dos usuários com empatia, a atenção dispendida ao paciente a fim de absorver a demanda e o apoio à família e paciente minimizando o sofrimento.

Eu não deixo familiar desamparado, não deixo o familiar sem informação. Toda informação que compete a minha função eu dou, com qualidade. Se eu não sei eu procuro saber, ajudo. A gente aqui recebe só duas visitas no horário da tarde e duas da noite, mas sempre que pode eu libero mais pessoas que eu acho que é importante esse convívio familiar. E5

Porque o paciente quando fica no CTI ele fica um bom tempo e a família fica muito debilitada. Então, eu acho que tem que cuidar também da família, não só do paciente. E20

Então, eu acho que o sentido que tem pra mim é tentar fazer esse momento ser um pouco mais acolhedor, um pouco menos traumático, tanto para o paciente quando para a família. E22

Eu não vou poder fazer aquela pessoa parar de sofrer, mas eu vou poder fazer com que aquela pessoa sofra mais acolhida, sabendo que ela não está sozinha. E22

Então, acho que é um local que você tem que ter muito cuidado ao manejo psicológico e também de procurar acolher esse paciente que 
todo mundo que está convivendo no ambiente do CTI, tanto família quanto paciente, estão num momento muito difícil da vida. E27

Outro aspecto que remete a contribuição do trabalho para a sociedade está associado à qualidade de vida. Os profissionais mencionaram que não é apenas ajudar ou acolher os pacientes e familiares, mas também procurar oferecer qualidade de vida para o paciente seja durante o processo de internação ou até mesmo com relação a sua reinserção na sociedade após a alta.

Tentar fazer com que o doente saia daqui com qualidade. E30

Eu acho assim, com relação à qualidade de vida mesmo. Contribui no sentido da pessoa valorizar a saúde, questão de prevenir problemas né!? Às vezes, a pessoa vem com exemplo do outro, pergunta pra gente como é que isso aconteceu, como é que funciona. E18

É estar devolvendo qualidade de vida para os pacientes. E27

Sabe-se que o paciente que se encontra no CTI está em situação extremamente grave e, muitos correm risco de morte ou de ficarem com alguma sequela. Assim, no cotidiano de trabalho da unidade e durante os manejos assistenciais foi possível observar que os profissionais expressam preocupação em resgatar a vida do indivíduo, mas também, em proporcionar condições de retorno às atividades de vida diária.

Eu acho que contribui é na qualidade de vida ne!? Eu acho que no CTI os profissionais estão muito preocupados em salvar vidas. Mas, além de estar preocupada em salvar uma vida eu também estou preocupada em dar qualidade de vida a essa vida que já foi salva. E2

Sem dúvida isso é algo importante para a sociedade, pra tentar dar condição de retorno daquele doente, inserir, retornar para o meio, para a sociedade da melhor forma possível. Porque o tratamento, reabilitar o doente, inicia no início do tratamento do quadro agudo, se a gente não pensar nisso nesse momento, não faz sentido. A gente tem que lembrar que aquele doente ele vai voltar pra sociedade. E31

Correr atrás pra fazer de tudo para que ele permaneça o menor tempo possível aqui dentro, ter alta do andar, depois voltar pra casa, tentar levar a vida, pelo menos, da forma parecida com que levava antes da internação. E18

Tipo, não devolver um paciente na horizontal para a sociedade. Tentar devolvê-lo mais funcional nos vários aspectos possível para a sociedade. Pra não ser um "peso" pra sociedade. E3 
De acordo com Morin (2001) realizar o trabalho com sentido é também, ter a oportunidade de prestar um serviço voltado para as pessoas permitindo melhorias na qualidade de vida da sociedade. Portanto, o profissional não deve prestar o serviço unicamente para cumprir o objetivo do trabalho, mas deve contribuir de alguma forma para sociedade.

Ressalta-se que o profissional é parte integrante da sociedade. Assim, realizar o trabalho em uma instituição pública proporciona o sentimento de contribuição já que os recursos públicos são aplicados na instituição e devem propiciar um atendimento de qualidade.

Acho que de uma forma geral, no emocional, no dinheiro público que é de todos nós ne!? E1

Eu acho mais interessante aqui, por ser um hospital público, em uma área que é de pronto atendimento eu acho que eu me sinto qualificado pelos anos que eu tenho de formado prestar um serviço de qualidade em algo público que até então, não era considerado né!? E6

Os profissionais mostraram-se comprometidos com a sociedade uma vez que sentem a necessidade de saber que seu trabalho colabora para as pessoas dentro e fora do ambiente de trabalho. O ambiente externo ao hospital também foi citado pelos profissionais uma vez que eles acreditam que outra forma de contribuir é fazer o trabalho de forma adequada para que a comunidade tenha segurança de que possuem um serviço público de qualidade:

Eu acho que no sentido mais deles terem uma visão boa mesmo do local né!? "Quando eu passar mal eu vou pra lá porque tem uma equipe boa". Conhecem pessoas que saíram daqui bem. E4

Eu acho que talvez até um conforto para o pessoal lá fora saber que no momento em que eles precisarem, estaremos aqui. Eu penso que é um conforto para a sociedade saber que na hora que precisar tem toda uma equipe diferenciada aqui para atender. E15

A terapia intensiva ela é uma necessidade crescente, um local de atendimento dos doentes graves, o local ideal pelo menos, por enquanto, que a gente enxerga de atendimento para esses pacientes graves e com risco de vida. E isso para a sociedade é uma segurança. E31

Perante a análise da dimensão social, apreendeu-se que essa é uma dimensão em que o indivíduo cumpre o seu papel como cidadão. Ele age conforme os princípios básicos em que a 
sociedade contemporânea se opera: em ajudar o próximo e buscar qualidade de vida. Além disso, trabalhar em um serviço público, bem como poder garantir o cuidado nesse espaço faz com que o profissional encontre sentido no trabalho. Os resultados dessa dimensão corroboram com os de Oliveira e Piccinini (2005) que ressaltaram que um trabalho com sentido é aquele que agrega valor tanto para quem realiza (os profissionais) quanto para quem se beneficia (a sociedade).

Dessa maneira, a dimensão social permitiu extrapolar a vivência do profissional da mentalidade organizacional prescritiva para um fazer humano, caracterizado pela dimensão subjetiva da organização que considera os sujeitos atores da micropolítica do processo do cuidado.

\subsubsection{Os Sentidos do Trabalho - Dimensão Fazer Cotidiano}

\section{Figura 6 - Imagem oriunda da Técnica do Gibi, 2013}

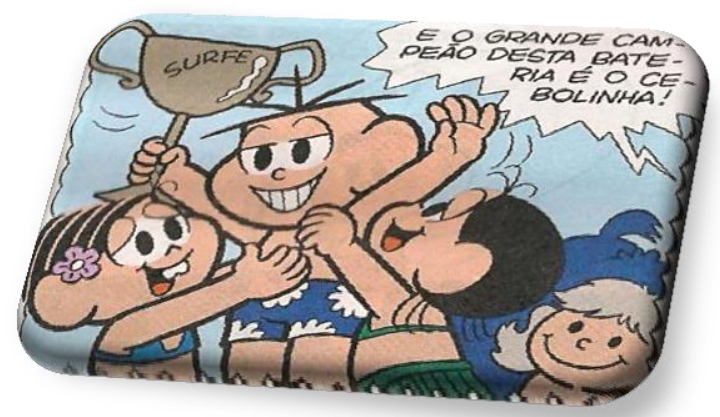

Porque tem sentido quando a gente toma umas atitudes e elas dão certo. Na verdade, não é pelas pessoas em volta, é pelo sucesso. Eu consegui, aquele doente estava muito grave, eu tomei tal atitude, deu certo e ele melhorou, então eu acho que é isso que motiva a gente. E11

Fonte: Dados coletados para fins deste estudo

A dimensão fazer cotidiano foi identificada a partir da análise dos depoimentos dos sujeitos no presente estudo. O comportamento dos profissionais e o discurso deles com relação ao cotidiano de trabalho e no ambiente de trabalho associados aos estudos feitos acerca do sentido do trabalho fizeram emergir essa nova dimensão dos sentidos do trabalho. As peculiaridades do trabalho no setor saúde fez com que novas questões do sentido do trabalho surgissem e/ou, até mesmo, as já existentes tomassem conotações diferentes.

O profissional da saúde é um dos atores do processo de trabalho em saúde e participa ativamente deste mundo do trabalho. Como afirmam Franco e Merhy (2007), o cotidiano de trabalho é visto como uma micropolítica na qual o indivíduo é fabricador e fabricado por ele, e não apenas capturado pela estrutura. Assim sendo, o fazer do profissional no cotidiano de 
trabalho é algo dinâmico e que possui uma relação dialética com a estrutura, com a organização e com as pessoas e, não apenas um "fantoche" que reproduz condutas.

A posição do profissional da saúde no contexto das organizações é de extrema importância, visto que o sentido do trabalho baseia-se, também, no modo como os indivíduos definem seus trabalhos e os modos de fazê-lo. Embora, essa percepção seja marcada pela subjetividade, ela é moldada por fatores considerados estímulos comuns a todos os profissionais que trabalham na organização (MORIN; GAGNÉ, 2009). Esses fatores se revelaram na análise dos depoimentos deste estudo, e diante disso, emergiu a necessidade de incorporar mais uma dimensão às dimensões do sentido do trabalho elaboradas por Morin, Tonelli e Pliopas (2007), a dimensão fazer cotidiano.

A dimensão fazer cotidiano agrega elementos das dimensões individual, organizacional e social. Contudo, merece destaque os elementos que ressignificam e legitimam o trabalho do profissional da saúde uma vez que representam a concretização do trabalho em ato. Nessa perspectiva, Franco e Merhy (2007) afirmam que em todos os ambientes em que se produz saúde opera no campo dos processos de subjetividade comprometida com a produção de sentidos para aquela prática. Logo, a subjetividade dos processos de trabalho em saúde é fundamental na construção do sentido e da concretização da sua prática produtiva.

Considerando o exposto, na presente dimensão emergiram questões relacionadas ao trabalho profissional no momento de sua execução e os resultantes do mesmo, quais sejam: o prazer em ver o seu trabalho realizado e a recuperação do paciente, a percepção da efetivação e utilidade do trabalho em ato, as formas de se realizar o trabalho e de tratar o indivíduo com singularidade e humanidade.

O trabalho em saúde é realizado por meio da ação de diferentes profissionais e resulta na assistência à saúde. $\mathrm{O}$ objeto do trabalho é o indivíduo que necessita de medidas curativas para preservar a saúde ou prevenir doenças (PIRES, 2008). Portanto, trata-se de "ações de pessoas (trabalhadores) sobre pessoas (pacientes/clientes) (SOUZA et al, 2010, p. 453). Contudo, essas autoras afirmam que o produto final da assistência é consumido em ato, não sendo possível palpá-lo uma vez que não é materializável. A despeito de não ser materializável, o mesmo é observável. A finalidade do trabalho no CTI é a recuperação do indivíduo fazendo-o sair da situação inicial que fez com que ele precisasse do serviço. Já o produto é visualizado na realização do trabalho por meio dos resultados de cada ação executada pelo profissional visando a finalidade do trabalho, que é a recuperação do paciente. 
A finalidade e o produto do trabalho em saúde foram percebidos na análise de depoimentos dos entrevistados. Com relação ao produto do trabalho, os profissionais demonstraram prazer em ver o seu trabalho se concretizado no indivíduo. Eles citaram situação como: a higiene do paciente por meio do cuidado prestado; a melhora das feridas devido ao cuidado técnico adequado, a evolução da independência do paciente devido ao esforço diário dos profissionais, além da redução do sofrimento do paciente:

O paciente melhorar, de você encontrar o paciente muito sujo e deixar ele limpinho e cheiroso sabe!? O cuidado mesmo com paciente. E4

Quando a gente vê que um paciente está melhorando pelos cuidados que a gente presta, porque as lesões dele não estão evoluindo ou estão regredindo. E13

Chega em um ponto que a gente consegue colocá-lo sentado no leito, ver que tem uma melhora no controle do tronco, consegue colocar de pé. Então, isso pra mim é muito gratificante. E16

Eu acho ótimo quando eu tiro o tubo do paciente, quando o paciente tá acordando eu puxo o tubo e o paciente começa a respirar sozinho e ele fica satisfeito. Às vezes, o paciente fica feliz quando você tira ele da poltrona, ou quando você chega pra atender e ele já sabe que você vai tirar. E18

É prazeroso sim, tirar um doente de uma situação crítica e trazê-lo de volta digamos assim, a vida, a recuperação de um quadro de risco de morte e contribuir para a recuperação daquele paciente, ajudá-lo, minimizar o sofrimento. E31

O produto do trabalho em saúde é consumido durante o fazer profissional, ou seja, na ação assistencial. Apesar de ser consumido ele é observável por meio da resposta do paciente à assistência prestado o que gera sentimentos de prazer e gratificação nos profissionais de saúde. Assim, o prazer na realização das atividades é considerado um dos fatores determinantes para que o trabalho tenha sentido (MORIN, 2001; OLIVEIRA; PICCININI, 2005).

Quanto à finalidade do trabalho, os achados do presente estudo corroboram com o de Souza et al (2010) que observou o prazer expresso pela recuperação e percepção da melhora do paciente e por ter ajudado com que ele saísse de uma situação de risco e tivesse a oportunidade de voltar para casa e se inserir novamente na sociedade: 
A melhora dos pacientes. A gente recebeu uma paciente na $5^{\mathrm{a}}$ feira que veio aqui da maternidade, muito grave [...] E hoje ela recebeu alta. Era uma paciente assim que teoricamente ela já tinha falecido. Isso me dá muita satisfação, isso me motiva muito. E5

Quando você chega lá na frente, que um paciente que às vezes não tem probabilidade nenhuma de sobreviver, e você vê lá, com dez, quinze dias, às vezes muitos dias, o paciente começa a falar, vai embora para a casa e volta a ter uma vida normal, isso é muito gratificante. E15

O maior prazer que a gente tem aqui é de ver o paciente sair bem né?! Chega um paciente crítico aqui e você vê que ele tá grave, não dá nada por ele e você vê o paciente sai conversando, falando. Pra gente o prazer maior é ver o paciente se recuperando. E21

Orgulho e do sentimento de gratificação de ver o paciente se reabilitando, se reinserindo na sociedade, se reinserindo no domicílio, nas vias de alta, na adequação para alta. Isso é muito gratificante, é um sentimento de satisfação de vida mesmo, orgulho de vida. E29

É prazeroso sim, tirar um doente de uma situação crítica e trazê-lo de volta digamos assim, a vida, a recuperação de um quadro de risco de morte e contribuir para a recuperação daquele paciente, ajudá-lo, minimizar o sofrimento. Eu acho que no quadro ali, no dia-a-dia do intensivista, a gente tem inúmeras histórias de casos que deixam marcas, umas não boas, mas muitas sim, gratificantes, de recuperação em que você pôde contribuir pra saúde daquele paciente que está gravemente acometido. E31

A finalidade do trabalho em saúde é de extrema importância para o profissional, pois permite ao profissional perceber sua contribuição para o paciente e que o objetivo do trabalho que ele se propôs a fazer foi concretizado de maneira efetiva, fazendo com que o profissional confira sentidos ao trabalho. Assim, o trabalho em saúde se expressar por meio da manutenção da vida do indivíduo no qual todos os recursos, o labor, os instrumentos, os saberes e os esforços foram direcionados para tal. De acordo com Souza et al (2010), a possibilidade de salvar vidas possui grande relevância no equilíbrio psíquico do profissional além de proporcionar conforto e satisfação, condições essas, como afirmam Morin e Gagné (2009), ideais para atribuir sentido ao trabalho.

Visto as colocações, o trabalho no CTI é produtor de cuidado, cujo objeto é o ser humano e a finalidade a recuperação da saúde, sendo essa uma das poucas maneiras de observar a concretização do cuidado. Portanto, de acordo com Franco e Merhy (2012), a micropolítica do processo de trabalho em saúde envolve o encontro dos usuários e 
profissionais no cenário de produção e efetivação do cuidado caracterizando o trabalho vivo. O trabalho vivo como afirma Merhy e Franco (2012 p. 153):

É o trabalho em ato, no seu exato momento de produção, criação, portanto se realiza na atividade do trabalhador. Sendo assim o trabalho vivo é de controle do próprio trabalhador, ele lhe oferece altos graus de liberdade na execução da sua atividade produtiva, pois se realiza enquanto o trabalho é executado, o produto é realizado (MERHY E FRANCO, 2012, p. 153).

Dessa maneira, o trabalho em saúde é um trabalho vivo, pois a prática do cuidado é realizado no momento do fazer, em ato e na relação entre os atores envolvidos (pacientes e profissionais). O processo de produção em saúde acontece na micropolítica da organização do fazer profissional. Portanto, o profissional precisa perceber o seu trabalho em ato para que o mesmo tenha sentido, pois aquele momento, único e transformador, é a representação do seu trabalho. Passado esse momento o trabalho se dissipa e novo ciclo se recomeça.

Neste estudo foi possível identificar nos depoimentos que os profissionais a percebem o trabalho em ato realizado representado pela melhora do paciente por meio do trabalho executado por eles, logo, os profissionais não sentem prazer apenas em ver o paciente se recuperando, mas em saber que contribuíram para tal.

Eu avalio um paciente e ele não tem condição de comer via oral, eu tenho que indicar uma via alternativa para ele e, com o meu trabalho, isso daqui a 2, 3 dias ou daqui a uma semana eu posso liberar uma dieta oral de modo seguro, isso pra mim é a melhor recompensa que tem. E2

Quando o paciente tem uma hemodiálise de urgência e o médico fala: "Eu preciso que você ligue agora". E você ter a capacidade de desenvolver rápido, de ligar o paciente e poder salvar uma vida. E7

Principalmente quando a gente vê que um paciente entrou um pouco mais debilitado e saiu do CTI bem, então isso faz a gente perceber que o nosso trabalho foi bem desenvolvido, que o paciente melhorou, então isso traz muito prazer para a gente. E17

A gente tem chance de fazer diferença pra pessoa que está internada aqui. Se conseguir fazer um bom trabalho tem uma chance de melhora. Caso contrário, pode ser que não né? E24

Enfocando os depoimentos, o trabalho em saúde se concretiza em ato, isto é, no seu fazer cotidiano. Portanto, permitiu perceber "o trabalho vivo em ato com toda sua intensidade na produção das "linhas de vida" dentro da organização e sua potencia instituinte" (FRANCO; 
MERHY, 2007, p.6). Os profissionais, além de perceberam a contribuição do seu trabalho, ressaltaram que as peculiaridades do processo de trabalho no CTI são facilitadores dessa percepção fazendo com que eles gostem de trabalhar no setor e se sintam realizados. Nessa ótica, a identidade social dos profissionais é reafirmada, além do prazer e de se sentirem importantes para o setor, já que o detalhe de uma ação modifica o todo:

Aqui você vê que as suas ações terapêuticas elas são mais imediatas e você consegue enxergar, de maneira mais rápida as suas ações. Isso te da uma realização de que a sua formação médica vale a pena, salva vidas né!? Mais rápida, mais imediata, é mais visível, é mais palpável. E6

Quando você percebe uma coisa que ninguém tinha visto e essa sua pequena percepção faz toda a diferença. Então, o fato de você, das suas atitudes, das suas posturas fazerem a diferença no CTI é muito gratificante. E11

De hoje, você chegar, você começar um trabalho, amanhã você dar continuidade nele e daqui uma semana, você ver que deu resultado, então você conseguir acompanhar esse trabalho. Por isso que eu gosto tanto de terapia intensiva, porque você consegue ter uma visualização do seu trabalho melhor. E15

Também merece destaque o fato de, o paciente que se encontra no CTI, na maioria das vezes, correr risco de morte. A perda do paciente é considerada pelos profissionais da saúde como a expressão da não concretização do trabalho. Nesse aspecto, Moritz (2005, p.51) atesta $\mathrm{o}$ ato de morrer "como o intervalo entre o momento em que a doença se torna irreversível e aquele em que o indivíduo deixa de responder a qualquer medida terapêutica, progredindo inexoravelmente para a morte". É o momento em que as condutas terapêuticas adotadas não geram resultados e o indivíduo vai a óbito. Dessa forma, a perda do paciente foi citada como motivo de sofrimento para os profissionais, dentre os motivos se destacam: a não efetivação do trabalho culminando com a morte do paciente; o trabalho não surtiu efeito em face da condição clínica do paciente; a frustração de fazer o melhor e o paciente vir a óbito; a situação complexa que é lidar com a díade vida e morte no trabalho e; a morte de pacientes jovens devido a fatores externos:

Eu acho que Deus colocou a gente aqui porque tinha que ser, porque a gente sabe que não é um trabalho fácil você lidar com pessoas, às vezes, é a vida e a morte o tempo todo. E18 
Sofrimento por causa de óbito, principalmente, em casos de óbito de pacientes jovens que não estavam doentes, de acidente. E22

O sofrimento surge como resposta à ineficácia das tecnologias acionadas e da mobilização de pessoal. A esse respeito, Borges e Mendes (2012) asseveram que a morte passa a ser um teste à competência do profissional sendo fonte de sofrimento e frustação para eles:

$\mathrm{Eu}$ acho que a perda quando você não consegue. Você fazendo as coisas e acaba que a pessoa morre. Ai é um motivo de sofrimento. E7

Tem uns casos que a pessoa se recupere vai embora, mas tem uns casos que a pessoa fica sofrendo, sofrendo, sofrendo. Você vai fazendo e não vê resultado sabe?! E9

Então, por mais que a gente às vezes faça o meio impecável, às vezes o fim é outro. E às vezes é meio frustrante, e principalmente quando a gente investe, investe, investe, corre atrás, corre atrás, corre atrás, e perde o doente. Acho que de tudo é o que mais desgasta. E11

O paciente que morre em menos de 24 horas sem você sabe o porquê que ele morreu isso me frustra, porque não deu tempo de eu chegar a uma conclusão e poder fazer. E6

Os profissionais da saúde, principalmente, os que atuam no CTI precisam estar preparadas para lidar com a morte e o sofrimento dos sujeitos ao redor deles. Como afirmam Borges e Mendes (2012), os profissionais, dificilmente, recebem informação e treinamento suficientes para lidarem com a morte e com seu processo. O hospital é um ambiente marcado pela constante luta entre a vida e a morte, como disserta Moritz (2005), e o profissional formado para lidar com a cura se sente angustiado e frustrado devido a morte de pessoas que estavam sob seus cuidados. Assim, quando os meios tecno-científicos não são capazes de tratar e recuperar o paciente, os profissionais não estão preparados para conviver com o seu sofrimento, bem como o do paciente e sua família. Diante disso, os profissionais criam mecanismos de defesa para lidar com a finitude da vida, e uma delas é o apego à crença (BORGES; MENDES, 2012).

Então, às vezes, um caso ou outro a gente fica chateado porque não conseguiu, a gente fez de tudo, mas o paciente não resistiu e veio a óbito. Ai a gente fica um pouco frustrado. Mas, eu acho que Deus sabe de todas as coisas, então assim, eu pelo menos tento pensar que eu fiz o que eu pude pelo paciente. Se o paciente não sobreviveu foi porque Deus achou que era a hora dele. E20 
Outro mecanismo de defesa é a negação do sofrimento, deslocando seus esforços para o desempenho da técnica profissional (BORGES; MENDES, 2012). O indivíduo canaliza e lida melhor com o sofrimento, pois realizou todas as condutas técnicas que deveriam ser feitas e por isso, possui a consciência tranquila de dever cumprido.

Tranquilidade de ter a certeza que eu vim aqui, prestei assistência a melhor que eu poderia ter prestado para os pacientes e que foi importante pra ele de alguma forma. Não necessariamente isso possa ter salvado uma vida porque, muitas vezes, independente da assistência que a gente preste não tem como a gente salvar todo mundo. Mas, de eu ter a tranquilidade de chegar na minha casa e saber que a minha parte foi feita. E13

Os resultados do trabalho na saúde são apreendidos no momento em que ele é realizado, portanto tanto o êxito no trabalho quando a falha são percebidos em ato e produzem efeitos no indivíduo, sejam de prazer ou sofrimento. Com relação ao sofrimento, os sujeitos da pesquisa citaram questões como: lidar com o sofrimento da família e do paciente e a empatia com a situação vivenciada pelo familiar e pelo próprio paciente.

É na verdade seria o sofrimento do outro que, muitas vezes, a gente acaba absorvendo, e transferindo pra gente. Pacientes novos que passam por uma patologia não muito favorável que já sabe o prognóstico é um pouco mais reservado. A gente acaba sofrendo em alguns casos específicos. E3

A dor dos familiares. Quando o médico vê que já não tem mais jeito isso me entristece muito. A tristeza de ver os parentes, vê os entes deles indo embora. E10

É duro pensar, é difícil, dói você pensar, principalmente, quando você se coloca no lugar do outro, do familiar que está sofrendo, e a pessoa que está ali no leito também, ela continuar sofrendo. E15

O horário de visita, eu sinto aquele momento da família que está acuada, de repente uma pessoa que era do convívio de repente tá acamada, não está conversando. Então, tem esse momento mesmo de angustia de o familiar está vendo esse ente querido. E16

O sofrimento do paciente é uma coisa que também acontece nessa especialidade. Você lida com muito sofrimento de doença, de sofrimento do indivíduo mesmo junto com a família, isso gera sofrimento também. E25 
Além disso, o profissional da saúde, ao se deparar com a morte do paciente se coloca no lugar do outro e percebe a finitude da sua própria vida, o que também lhe causa sofrimento (MORITZ, 2005).

Situações que você vê pessoas da sua idade, às vezes, pessoas que você conhece. Em outras situações da vida, talvez em condições social diferente, mas você, às vezes, se enxerga no caso de um acidente de trânsito, ás vezes, em caso de assalto. As pessoas são trazidas para cá, então a gente sente um pouquinho naquela situação. Então, isso me causa sofrimento, talvez, na equipe. E27

Considerando a percepção do trabalho em ato e as características do ambiente que potencializam tal percepção, Morin e Gagné (2009) ressaltam que o sentido do trabalho depende da consistência entre o profissional e o seu trabalho, suas expectativas, valores e ações em seu cotidiano. Portanto, são fatores que contribuem para que um trabalho tenha sentido e, consequentemente, faz com que o profissional busque cada vez mais realizá-lo da melhor forma possível para que os sentimentos com relação ao trabalho despertem e ele encontre prazer e satisfação. Portanto, o sentido do trabalho não depende apenas dos profissionais, pelo contrário, depende também de como o trabalho é estruturado física e psiquicamente.

Quando as características e a estruturação do trabalho não estão em consonância com as expectativas do profissional isso pode gerar situações de estresse no profissional e consequente mal estar. Morin e Gagné (2009) alegam que as características das tarefas e condições de trabalho podem ser uma fonte de estresse, desigualdades e riscos para a saúde dos trabalhadores. Os sujeitos associaram o estresse no trabalho à agitação da dinâmica do CTI que os deixam cansados, a carga horária pesada, a sobrecarga emocional devido à gravidade do doente e a responsabilidade do trabalho:

Estou estressado, estou cansado entendeu? A maioria dos plantões são muito estressante. É uma correria tem dia, um grita de lá, um grita de cá, você ajuda um, ajuda o outro. E5

Ah, eu acho que eu tenho muita satisfação pessoal no trabalho, mas aumenta o meu nível de estresse bastante. Acho que eu sou uma pessoa um pouco estressada por conta da carga horária e do tipo de vida que eu levo. E11

Eu acho que por ser pacientes críticos há uma sobrecarga emocional. Pelo menos eu sinto assim, eu não chego em casa só com o desgaste físico, sabe aquele desgaste mental mesmo? Um cansaço, parece que 
suas energias ficam todas aqui no seu ambiente de trabalho. Eu fico realmente esgotada. E14

São pessoas muito doentes, e isso traz certo desgaste você que está aqui o tempo inteiro [...]. Eu acho que o trabalho que a gente faz aqui é muito bacana, que a gente vem todo dia, a gente acompanha os doentes muito de perto. Você vê tudo que está acontecendo. Mas, por outro lado isso traz certo desgaste, até muito emocional eu acho. E24

A gente tem situações estressantes, emergências que você tem que atuar sempre de forma, naquele momento é um estresse, uma adrenalina ali daquele momento da emergência. Às vezes, mais de uma situação de emergência simultânea. E31

Apesar de que eu gosto muito, eu acho que é um lugar que te consome muito, que você tem que ter muita responsabilidade, você tem que ter muito cuidado e a questão de ser cansativo. É muito cansativo, é muito pesado, é uma cobrança muito grande das outras pessoas, e uma cobrança sua também porque você quer fazer o melhor pelo paciente. E32

Os depoimentos demonstraram que as características do trabalho são consideradas estressantes para os profissionais da saúde que atuam no CTI. Morin e Gagné (2009) afirmam que o profissional que possui visão negativa do trabalho tende a não encontrar sentido no mesmo já que o ambiente em que trabalham não é favorável levando-os a terem sintomas de estresse bem como problemas de saúde. Ressalta-se que não se pretende abarcar as possíveis doenças psicossomáticas que afetam os profissionais quando acometidos por estresse ocupacional, entretanto, destaca-se a importância de se ater às características que os profissionais reconhecem como estressantes uma vez que é o primeiro passo para que alguma patologia se instale e, assim, agir antecipadamente contra esses fatores.

Diante disso, Ulhôa et al (2011) referem que o estresse ocupacional é o processo em que o profissional é capaz de reconhecer alguns fatores do trabalho como possível fonte de estresse que, ao exceder sua capacidade de enfrentamento, pode gerar doenças vinculadas ao trabalho. O bem estar do trabalhador requer, por parte da organização, a implantação de políticas de prevenção e estimula uma cultura organizacional que garanta a qualidade de vida dos profissionais (ULHÔA; GARCIA; LIMA; CASTRO 2011). Portanto, demonstra que é elementar identificar sinais de estresse ocupacional nos profissionais para que medidas sejam adotadas antes que algum agravo acometa o profissional, sendo um problema para a organização, para o indivíduo e, consequentemente para o trabalho prestado. 
O profissional que percebe seu trabalho como negativo e como um potencial gerador de estresse cria mecanismos de defesa, fazendo com a sua presença no ambiente de trabalho e seu compromisso com a organização tenha redução na qualidade. Assim, não há esforço e a vigilância fica prejudica devido ao estresse e aumentam os riscos de erros, negligências, acidentes e, também afeta o desempenho (MORIN; GAGNÉ, 2009).

Outro aspecto desta dimensão é o sentido de responsabilidade pelo trabalho realizado. Foi observado nos depoimentos que os profissionais se referem ao senso de responsabilidade por meio da menção às tarefas e atividades que desenvolve no seu cotidiano de trabalho, ou seja, ao ser profissional:

Eu sou responsável pela hemodiálise. Os pacientes descem, aqui a hemodiálise é do boxe 6 ao 16 aqui, e lá no CTI 3 todo. Eu sou responsável pela máquina e pelo paciente. E8

Significa pra mim uma força de vontade muito grande, uma responsabilidade. E10

A gente fica responsável por entorno de 10 a 8 leitos, vai depender da escala que a gente tiver no plantão. Então, a gente é responsável pela parte funcional do paciente, responsável também por olhar raio-X, olhar exame laboratorial e os cuidados referentes à fisioterapia. E16

A gente é responsável pela assistência geral e pela supervisão destes três pacientes. E17

Olha eu sou responsável por todos os materiais e equipamentos do CTI, né!? O material respiratório, os materiais, respiradores, cabos, bombas de infusão. Então, eu sou responsável, tem sempre que manter o material, repor, todo o material esterilizado pegar o material, levar para ser reesterilizado na CME, né!? E21

O senso de responsabilidade do trabalho e de se encarregar das atividades são considerados aspectos importantes na atribuição dos sentidos ao trabalho. Segundo Baasch e Laner (2011), os indivíduos além de considerar o trabalho como contribuição social também o caracteriza como uma responsabilidade. A responsabilidade está relacionada ao comprometimento em realizar a atividade (algo que se deve fazer), à obrigação diária que está imbricada na escolha profissional e ao setor de atuação. Características que valorizam o trabalho demonstrando que é exigido alto grau de responsabilidade para exercê-lo. Desse modo, um trabalho que tem sentidos permite que o profissional perceba sua contribuição e também a responsabilidade no trabalho executado (MORIN; TONELLI; PLIOPAS, 2007; MORIN, 2002). 
Outro aspecto encontrado nesta dimensão foi a necessidade dos profissionais em identificarem a utilidade do seu trabalho. Neste caso, observou-se o se sentir útil, o prazer em perceber a utilidade social do seu trabalho na vida de outras pessoas, a ocupação que o trabalho possibilita a utilidade em estar disponível para atender às demandas e a própria contribuição da profissão para a melhoria do paciente:

Eu acho que o grande prazer é ser útil né!? Pelo meu conhecimento você salvar vidas, que são vidas teoricamente não tão valorizadas, porque aqui é uma população mais carente, com pouco acesso [...] E a satisfação de ser como profissional e de ter sido útil, isso que supera tudo. E6

Então, eu desejo para minha vida como para minha profissão é ser útil, ser útil de alguma forma, seja através da profissão, seja através dos meus atos, seja através daquilo que eu possa ou tenha potencial de ser [...] Eu acho que é essa questão de você acordar e falar: "Poxa, hoje eu posso ser útil". E6

Ver a melhoria dos pacientes, satisfação pessoal de estar fazendo alguma coisa, entendeu? [...] Eu acho que a gente se sente útil, eu acho que eu não ia me sentir tão útil se eu saísse daqui do CTI. E8

De me sentir útil, eu ajudei para você sair e você está me reconhecendo. Isso é muito bom pra gente. E9

O mais importante no trabalho é a gente ser sempre útil né?! [...] Eu me sinto realizado e sou útil pras pessoas. Isso me motiva todos os dias, eu não falto, entendeu!? Então, eu sou útil pra eles, precisam de mim, então me chamam pra todos os lados e eu estou aqui útil. E21

Eu acho que contribui assim, você vê que você fez o seu trabalho e que o paciente está melhorando. Ai você tem aquela gratificação de poder ajudar outras pessoas com aquilo que você estudou, com aquilo que você escolheu. E32

Ressalta-se que a utilidade do trabalho superou a ideia de ser apenas uma ocupação, mas sim no sentido de contribuição social do trabalho, isto é, ser útil no fazer cotidiano. De acordo com Morin, Tonelli e Pliopas (2007), para que um trabalho seja considerado útil o seu produto deve servir a algum propósito. Como o produto em saúde é a recuperação do paciente devido à ação desenvolvida pelo profissional, percebeu-se pelo trabalho descrito pelos entrevistados que ele assume a conotação de utilidade. Nesse sentido, Morin (2002, p.72) aponta que "executar tarefas que não têm utilidade prática, que não comportam nenhum interesse, em um meio ambiente onde as relações são superficiais, torna o trabalho absurdo”. 
Ainda, postos depoimentos revelaram utilidade do trabalho como ocupação diária. Nesse aspecto, Morin (2001) afirma que um trabalho com sentido permite ao indivíduo se manter ocupado, preencher suas aspirações espirituais dando sentido à vida. Mais uma vez, surge a relação do trabalho com a vida pessoal, sendo que as duas esferas são interdependentes e, o trabalho, ocupa lacunas da vida pessoal e essa preenche o trabalho, em uma relação dialética.

A dimensão fazer cotidiano enfocou questões no trabalho vivo em ato, característica inerente da micropolítica do processo de trabalho em saúde. Abordou questões desde o prazer, puro e simplesmente em ver a recuperação do paciente, até a responsabilidade e utilidade que o trabalho do profissional assume para que culmine com a recuperação, finalidade do trabalho em saúde. Contudo, o trabalho vivo em ato não proporciona apenas prazer. A dinâmica do CTI e a estrutura do trabalho propiciam sentimentos de estresse. O sofrimento foi destacado pelos profissionais no que concerne à proximidade com morte dos pacientes e da sua própria, além de terem que lidar com o sofrimento inerente desse processo quando do padecimento da família e/ou do paciente. Portanto, essa dimensão retratou a realidade do cotidiano dos profissionais da saúde e os fatores que são importantes, relacionados ao seu fazer profissional, na atribuição de sentido ao trabalho que devem ser salientados nas políticas de gestão de pessoas assim como o comportamento dos gestores para que o ambiente de trabalho seja passível de ter sentido. 


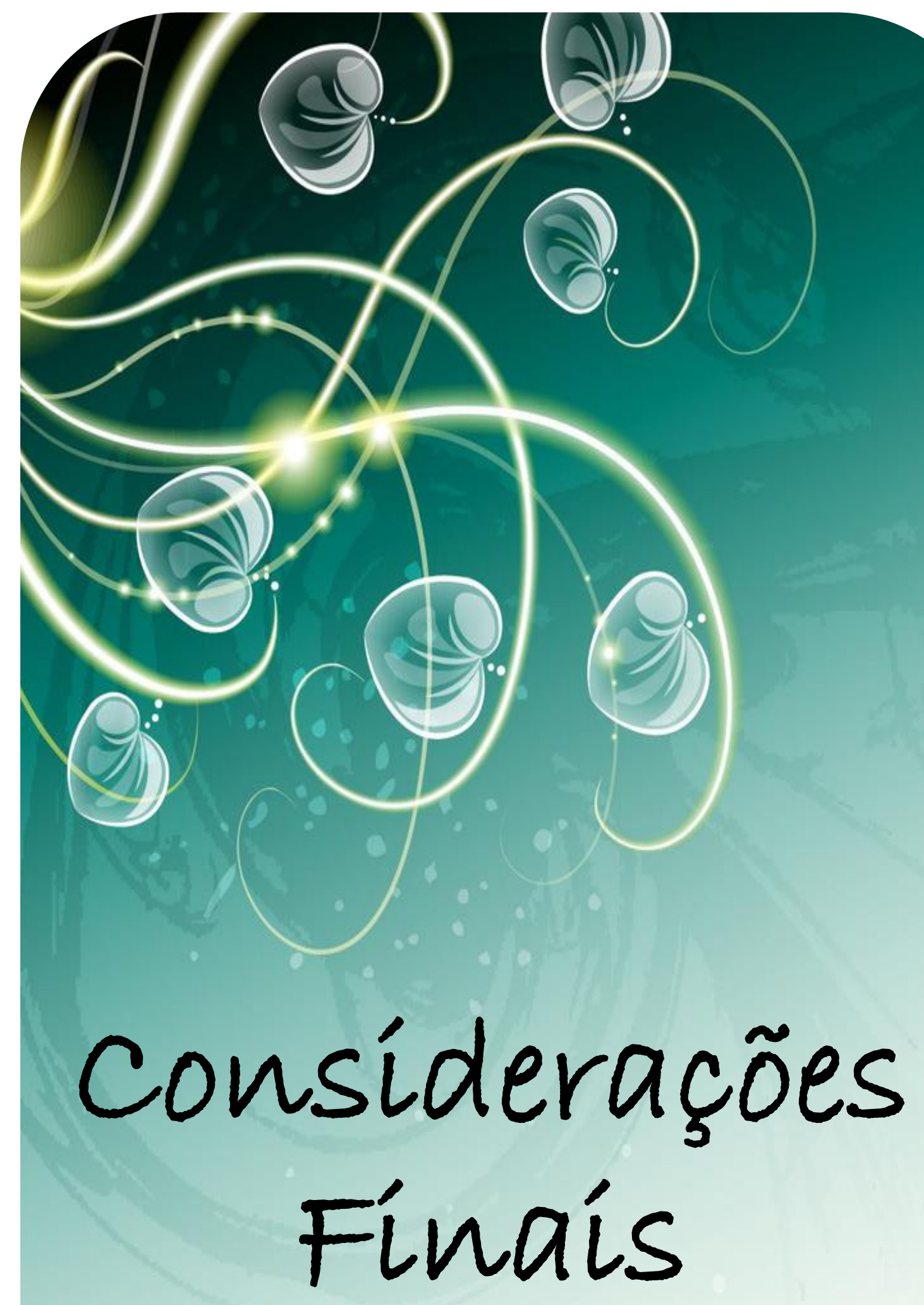




\section{CONSIDERAÇÕES FINAIS}

Os profissionais da saúde conferem sentidos ao trabalho de uma forma multivariada sendo vários os fatores que influenciam na forma como vivenciam e percebem o seu trabalho e de como isso repercute na representação de sua vida pessoal e profissional e, por conseguinte, nos sentidos do trabalho. A organização do trabalho e suas características são importantes na análise dos sentidos do trabalho visto que mobilizam e sensibilizam o profissional a se predispõem ou não para o trabalho. Assim, a expectativa com relação ao trabalho, à motivação do profissional em continuar realizando-o e à percepção positiva do mesmo, se revelam.

A perspectiva analítica utilizada no presente estudo dos sentidos do trabalho foi baseada nas dimensões dimensão individual, organizacional, social e do fazer cotidiano.

$\mathrm{Na}$ dimensão individual foram abordados aspectos do cotidiano profissional dos sujeitos que ecoam em suas vidas privadas e também no trabalho. Os depoimentos reforçaram achados da literatura de que a vida pessoal e profissional não são distintas, havendo importantes espaços de interseção entre ambas.

A atividade profissional se revelou como um importante aspecto na construção identitária dos profissionais da saúde, haja a relevância dos processos de socialização. Desse modo, foi possível perceber a construção e a reformulação da identidade social real, isto é, a identidade para si por meio do reconhecimento que possuem do seu trabalho. Assim, ao se identificar com a atividade realizada e conferir sentidos ao trabalho o sujeito reforça sua identidade.

Entretanto, percebeu-se que o profissional enfermeiro vivência rupturas identitárias em decorrência de contradições referentes às suas expectativas da profissão durante a inserção no mercado de trabalho. Observou-se que existe a dicotomia entre o que esperam e absorvem durante a formação e a realidade dos serviços no cotidiano de trabalho.

Destaca-se que traços da identidade virtual foram identificados nos depoimentos dos sujeitos ao se colocarem no lugar do outro com relação ao reconhecimento que acreditam ter por parte da equipe, dos dirigentes do hospital e dos pacientes e familiares. Esse aspecto se revelou importante porque o profissional precisa ter o reconhecimento dos que se beneficiam com sua atividade para que ele possa se auto reconhecer e conferir sentidos ao trabalho. Ademais, o reconhecimento é um importante fator motivacional no trabalho.

Atrelado à questão da identidade, outro aspecto identificado na dimensão individual foi o fato de os sujeitos visualizarem o seu trabalho como fonte de prazer. O prazer desvelou- 
se na realização profissional, no cuidado ao paciente crítico, no gostar do que faz e na experiência de trabalhar com seres humanos e poder ajudar de alguma forma. Ademais, o CTI configura-se como um espaço de aprendizado constante visto a gravidade e complexidade do paciente e as possibilidades terapêuticas que são mobilizadas para atendêlos, revelando-se como um trabalho desafiador. Por se tratar de um hospital universitário, a gama de novos conhecimentos e saberes se expande oferecendo melhores oportunidades de aprendizado para os profissionais que ali atuam. A questão financeira foi citada pelos entrevistados como um fator importante, mas surgiu de forma secundária na atribuição de sentidos do trabalho. Apesar de não ser central, a remuneração pode ser considerada como um “termômetro" para os dirigentes da organização, pois quando a estruturação da instituição e do trabalho não atende às expectativas dos profissionais, ela ressurge atrelada às questões negativas do trabalho.

Ressalta-se que embora os sujeitos busquem se desenvolver no interior da organização e crescer profissionalmente, eles também buscam qualidade de vida fora do trabalho. Os profissionais consideraram que o trabalho pode proporcionar qualidade de vida para conquistarem tranquilidade e equilíbrio entre trabalho e vida social. Neste aspecto, surgiram questões no ambiente de trabalho que não contribuem para essa harmonia, as quais se destacam: a elevada carga horária de trabalho, a desvalorização da profissão face ao mercado de trabalho e a baixa remuneração.

Os elementos que conferem sentidos ao trabalho relacionados à dimensão individual reforçam a necessidade de valorizar e (re)valorizar o trabalho dos profissionais da saúde nas organizações, estando intimamente associados às políticas de gestão de pessoas. Percebeu-se que o trabalho possui relevância na vida social dos profissionais e, portanto, precisa ser cuidadosamente planejado a fim de prezar pela dimensão subjetiva das organizações que interfere nos sentidos do trabalho e, consequentemente, na atuação profissional.

A dimensão organizacional interpelou a identificação do profissional com a organização reforçando as particularidades dos sentidos do trabalho para os profissionais da saúde. A identificação se torna importante porque a organização estrutura seu trabalho de forma que os profissionais sejam direcionados a cumprir com as normas e metas institucionais. Entretanto, se os profissionais não as identificam o trabalho perde o sentido e a motivação. Na saúde, a identificação se torna relevante visto que o objeto de trabalho é um ser humano fragilizado necessitando de cuidados diferenciados e, portanto, o profissional deve envidar esforços na qualidade da assistência. 
Desse modo, foram identificados os laços afetivos, ideológicos, econômicos e psicológicos. O laço econômico foi atrelado à dimensão individual do trabalho quando os sujeitos abordam a questão da remuneração como uma necessidade visto que trabalham porque também precisam do dinheiro.

O laço afetivo foi visualizado no trabalho em equipe e no relacionamento interpessoal já que os profissionais se voltam aos objetivos organizacionais baseado no relacionamento positivo com sua equipe. O trabalho em equipe multiprofissional no CTI foi apontado como fonte de motivação para que os profissionais realizem suas atividades e, até mesmo, se mantenham na instituição. Ademais, trabalhar coletivamente permite que os profissionais compartilhem o trabalho e a responsabilidade sobre ele, sendo os resultados positivos ou negativos das atividades fruto do trabalho em equipe. Observou-se também que os relacionamentos interpessoais extrapolaram a perspectiva profissional e assumiram proporções na vida social dos sujeitos. Portanto, o laço afetivo foi considerado um fator motivador e auxiliar na atribuição de sentido ao trabalho uma vez que engloba a vida pessoal e profissional.

Outro aspecto revelado foi o relacionamento interpessoal com os pacientes e familiares. Apesar de os profissionais racionalizarem o envolvimento com eles, o cuidado integral e a convivência diária faz com que estabeleçam relações próximas e, até mesmo, afetivas. Dessa forma, as relações interpessoais são fonte de satisfação bem como são produtoras de sentidos e realização para os profissionais da saúde.

Assim, é preciso estimular no ambiente as relações humanas (tecnologias leves) e capturar a subjetividade para que o trabalho tenha sentido. Entretanto, os profissionais encontram problemas na atuação multiprofissional quando se trata da categoria profissional médica. A hierarquia médica sobre as condutas e a condução da equipe é fator de incômodo para as demais categorias profissionais fragilizando a atuação coletiva e a motivação para o trabalho.

Outro aspecto importante está ligado ao laço ideológico foi representado pela estrutura, política e dinâmica do setor assim como o comprometimento organizacional. O laço ideológico refere-se à visão que os profissionais possuem do ambiente. Eles consideram que a estrutura física do setor e a disponibilidade e alocação dos equipamentos/materiais oferece segurança para a atuação profissional. Ademais, possuem condições trabalhistas definidas o que os motiva a se manter na instituição. Associado à isso, a compatibilidade do perfil dos profissionais com a dinâmica do setor fortalecem os laços ideológicos. Dessa forma, esse laço 
é originador dos sentidos do trabalho visto que é necessário considerar um ambiente propício para o profissional atuar de forma adequada.

O laço psicológico destacou-se porque os profissionais, mesmo identificando algumas contradições em seu ambiente de trabalho (carga horária, sobrecarga de trabalho e alguns problemas de infraestrutura), ainda se sentem vinculados à organização e, consequentemente, se comprometam com a organização evitando desvios de comportamento como faltas, atrasos e conflitos. Portanto, o laço psicológico demonstra que o profissional possui forte ligação com a organização a ponto de conviver com as contradições e permanecer na instituição procurando alcançar os objetivos do seu trabalho de forma comprometida.

O comprometimento organizacional está associado ao laço psicológico, pois o profissional cria estratégias para transpor os sentimentos dúbios que possui com a organização e consegue agir voltado para as políticas organizacionais. Entretanto, o comprometimento se fragiliza em face à coordenação inflexível e que não adota posturas participativas.

A dimensão organizacional, associada aos laços de identificação com a instituição revela a importância da estrutura e das condutas tomadas pelos dirigentes do hospital como decisivas no modo de atuar do profissional. Quando o sujeito se identifica ele é capaz de modificar seu comportamento em prol da organização além de atuar com prazer, comprometimento e ética, o que faz com o trabalho tenha sentido. Portanto, as organizações precisam oferecer ambientes adequados e com relações facilitadas para que o profissional se identifique com o local de trabalho e atribui sentido a ele.

A Dimensão social englobou a contribuição que o trabalho propicia para a sociedade. O profissional sente-se com o "dever foi cumprido" quando visualiza que colaborou de alguma forma para a sociedade. Observou-se que ajudar o próximo que foi considerado como uma doação ao outro é uma forma dos profissionais se perceberem como cidadãos. o. Outro aspecto diz respeito ao ato de acolher o paciente e seu familiar com empatia, carinho, atenção e escuta, fazendo do profissional um conforto para o momento de sofrimento.

Apesar de estarem alocados em um setor no qual prestam cuidados ao paciente crítico, os profissionais se preocupam com a qualidade de vida dos pacientes durante o processo de internação e também para a futura reinserção na sociedade. Além disso, o trabalhar em uma instituição pública também se configura como uma contribuição para a sociedade.

Essa dimensão demonstra que o trabalho não pode ser exclusivamente normativo baseado em tecnologias duras e leve-duras, ele precisa ser voltado para a subjetividade, no resgate do indivíduo em sua condição existencial de ser humano. Portanto, a gestão deve 
encontrar meios de valorizar o fazer profissional como uma forma de utilidade social para que o profissional encontre sentido no trabalho que realiza.

A dimensão fazer cotidiano foi a categoria que surgiu face à análise dos dados empíricos do presente estudo. O trabalho cotidiano em saúde envolve questões relacionadas à organização e ao indivíduo, desde a estrutura até as relações sendo, portanto, dinâmica. Desse modo, essa dimensão agrega a essência das demais dimensões e, assim ressignifica e concretiza o trabalho em saúde e os sentidos que ele possui para os profissionais.

Ressalta-se a necessidade de visualização do produto final do trabalho para que o profissional perceba a sua contribuição e o trabalho passe a ter sentido. Assim, os profissionais sentem a necessidade de perceberem a recuperação do paciente e situações que demonstrem sua evolução, bem como a forma de atingi-la, para que atribua sentidos ao trabalho.

O profissional da saúde, perante a recuperação do paciente em risco iminente de morte vivenciam sentimentos de prazer uma vez os resultados do trabalho foram positivos e percebidos, especialmente, quando isso se materializa em uma vida humana salva, além de o sentimento de "ser útil" na vida das pessoas.

Salienta-se que a morte, para os profissionais da saúde que atuam no CTI, representa além da perda de uma vida a não efetivação do seu trabalho, sendo considerada um momento de sofrimento para a equipe. Para minimizar o sofrimento os profissionais recorrem à crença $\mathrm{e}$ utilização do conhecimento técnico. Desse modo, no fazer profissional dos sujeitos coexiste o prazer (recuperação do paciente) e o sofrimento (morte e sofrimento dos familiares).

Ademais, as características das tarefas e as condições para realizá-las necessitam estar em consonância com as expectativas dos profissionais, pois, quando isso não acontece, o trabalho passa a ser fonte de estresse e riscos para a saúde. Neste caso, os profissionais identificaram como fontes de estresse a agitação do setor, a carga horária pesada, a sobrecarga emocional e a elevada responsabilidade do trabalho. Desse modo, perceberam o trabalho negativamente o que interfere desfavoravelmente nos sentidos atribuídos ao trabalho podendo acarretar doenças ocupacionais. Assim, a gestão de pessoas deve encorajar uma cultura organizacional voltada para o bem estar no trabalho, enfatizando políticas de prevenção que minimizem os fatores negativos referentes ao ambiente interno proporcionando benefícios para a saúde do trabalhador.

Visto o exposto, um trabalho que possui sentido para profissionais da saúde que atuam no CTI de um Hospital Universitário, precisa possuir algumas características, dentre as quais se destacam: ser fonte de prazer e de relações interpessoais (profissionais e sociais); permitir o 
aprendizado e o crescimento; oferecer um salário adequado às atividades realizadas; concede reconhecimento e reforça a identidade social; propiciar a identificação e o comprometimento organizacional; possuir valor social e utilidade e; permite que o profissional perceba a efetivação do trabalho em ato.

As dimensões dos sentidos do trabalho, portanto demonstraram a importância da estrutura organizacional para que o profissional consiga encontrar sentidos no trabalho. Salienta-se que o trabalho é central na vida dos sujeitos além de estar associado à vida pessoal permitindo que eles se constituam, reformulem e se descubram como sujeitos ativos no fazer e viver, sendo relevante na configuração identitária. Entretanto, observaram-se contradições no cotidiano de trabalho com relação às expectativas profissionais e a realidade do serviço, além de questões morais que deslocam os profissionais do fazer profissional prejudicando a atribuição de sentido ao trabalho provocando rupturas identitárias, principalmente, nos enfermeiros.

Portanto, esse estudo pode contribuir para a reformulação na gestão de pessoas nos serviços de saúde como meio de revalorizar o trabalho a fim de lhe conferir sentido visto que permitiu a observação de aspectos considerados essenciais pelos profissionais. Ainda, aponta a necessidade de articulação entre os objetivos organizacionais e os valores e princípios dos profissionais estimulando o comprometimento organizacional. Pode, ainda, auxiliar na discussão acerca da cultura organizacional enfatizando a dimensão subjetiva do trabalho, pois a mesma possui papel fundamental no cuidado nos serviços de saúde.

Os resultados dessa pesquisa apontaram, ainda, a necessidade de se repensar e reestruturar o processo formativo dos profissionais condizentes com a realidade dos serviços e com a demanda da clientela assistida. Especialmente com relação à formação dos enfermeiros, observou-se que eles se inserem no mercado de trabalho, inseguros tecnicamente, pois na prática vivenciam experiências profissionais contrárias às absorvidas e esperadas durante a graduação.

Ademais, as características do setor saúde, principalmente, do CTI, no que concerne às relações intensas e próximas e a não materialidade do trabalho em saúde que é consumido no ato do seu fazer (trabalho vivo) fez surgir uma nova dimensão dos sentidos do trabalho, a dimensão fazer cotidiano.

Esse estudo não pretendeu esgotar as possibilidades para esse tema, pelo contrário, suscitou novas questões. O setor saúde, especialmente o CTI, é permeado por intenso processo de socialização que reflete diretamente no fazer profissional. Na prática cotidiana no CTI os profissionais vivenciam situações repletas de contradições que são fontes de 
sentimentos de desigualdade, sofrimento moral, dilemas éticos, caracterizando, por vezes, fragilidade nas relações além de impacto negativo na assistência ao paciente. Dessa forma, o sofrimento moral dos profissionais da saúde se apresenta na prática como uma realidade que interfere na configuração identitária dos sujeitos, além de ser fortemente influenciado pelas questões organizacionais e gerenciais, aspectos esses, consolidados pelos sentidos do trabalho. Portanto, esse estudo aponta a necessidade de estudos que articulem o sentido do trabalho ao sofrimento moral de profissionais de saúde que atuam no CTI visto que essas temáticas possuem relação fundamental que influencia no comportamento dos profissionais.

O presente estudo foi realizado em um contexto hospitalar, especificamente, no CTI e por isso, possui limitações quanto à generalização dos resultados, em face à natureza qualitativa adotada. Dessa forma, é pertinente que novos estudos acerca dessa temática sejam realizados. 


\section{REFERENCIAS}

ALMEIDA, P. J. S.; PIRES, D. E. P. O trabalho em emergência: entre o prazer e o sofrimento. Revista Eletrônica de Enfermagem, Goiânia, v. 9, n. 3, p. 617 - 629, set./dez. 2007.

ALVES, M.; MELLO, R. A. Trabalho em equipe entre profissionais da enfermagem em um centro de terapia intensiva. Ciência, Cuidado e Saúde, Maringá, v. 5, n. 3, p. 299-308, set./dez. 2006.

ANTUNES, R. O trabalho e seus sentidos. Revista Debate \& Sociedade, Uberlândia, v.1, n. $1,2011$.

ARAÚJO, R. R.; SACHUK, M. I. Os sentidos do trabalho e suas implicações na formação dos Indivíduos inseridos nas organizações contemporâneas Revista de Gestão USP, São Paulo, v. 14, n. 1, p. 53-66, jan./mar. 2007.

ARREGUY-SENA, C.; ROJAS, A. V.; SOUZA, A. C. S. Representação social de enfermeiros e acadêmicos de enfermagem sobre a percepção dos riscos laborais a que estão expostos em unidades de atenção á saúde. Revista Eletrônica de Enfermagem, Goiânia, v.2, n.1, jan./jun. 2000.

AYRES, J. R. C. M. Cuidado e reconstrução das práticas de Saúde. Interface Comunicação, Saúde, Educação, Botucatu, v.8, n.14, p.73-92, fev. 2004.

BAASCH, D.; LANER, A. S. Os significados do trabalho em unidades de terapia intensiva de dois hospitais brasileiros. Ciência \& Saúde Coletiva, Rio de Janeiro, v. 16, p. 1097-1105. Jan. 2011. Suplemento 1.

BARDIN, L. Análise de conteúdo. Lisboa: Edições 70, 2009.

BAUMAN, Z. Identidade: entrevista a Benedetto Vecchi. Tradução de C. A. MEDEIROS. Rio de Janeiro: J. Zahar, 2005.

BOMFIM, R. C.; SOARES, D. A. Percepção de enfermeiros quanto Ao trabalho na unidade de terapia Intensiva: uma relação de prazer e sofrimento. Revista Eletrônica da Fainor, Vitória da Conquista, v.4, n.1, p.130-143, jan./dez. 2011.

BORGES, M. S.; MENDES, N. Representações de profissionais de saúde sobre a morte e o processo de morrer. Revista Brasileira de Enfermagem, Brasília, v. 65, n. 2, p. 324 - 331, mar./abr. 2012.

BORGES, L. O.; FILHO, A. A. A mensuração da motivação e do significado do trabalho. Estudos de Psicologia, Natal, v. 6, n. 2, p. 177 - 194, out. 2001.

BRASIL. Ministério da Saúde. Conselho Nacional de Saúde. Resolução n. 466 de 12 de dezembro de 2012. Aprova as diretrizes e normas regulamentadoras de pesquisas envolvendo seres humanos. Publicada no Diário Oficial da União, nº 12, seção 1, p. 59, 2012. 
BRASIL. Ministério da Saúde. Secretaria de Gestão do Trabalho e da Educação na Saúde. Departamento de Gestão da Educação em Saúde. Política Nacional de Educação Permanente em Saúde. Brasília: Ministério da Saúde, 2009.

BRASIL. Ministério da Saúde. Secretaria de gestão do trabalho e da educação na saúde. Departamento de gestão e da educação na saúde. Curso de formação de facilitadores de educação permanente em saúde: unidade de aprendizagem - trabalho e relações na produção do cuidado em saúde. Rio de Janeiro: FIOCRUZ, 2005.

BRAVERMAN, H. Trabalho e força de trabalho. In: Trabalho e capital monopolista: a degradação do trabalho no século XX. 3 ed. Rio de Janeiro: Zahar, 1987.

BRITO, M. J. M. A configuração identitária da enfermeira no contexto das práticas de gestão em hospitais privados de Belo Horizonte. 2004. 393p. Tese (Doutorado em Administração). Faculdade de Ciências Econômicas da Universidade Federal de Minas Gerais/UFMG, Belo Horizonte.

BRITO, M. J. M.; MONTENEGRO, L. C.; ALVES, M. Experiências relacionais de poder e gênero de enfermeiras gerente de hospitais privados. Revista Latino-Americana de Enfermagem, Ribeirão Preto, v. 18, n. 5, p. 1- 9, set./out. 2010.

CARVAlHAES, F. F.; KURIKI, K. A.; SILVA, R. B. Subjetividade e trabalho: debates contemporâneos sobre gestão de pessoas. Revista Científica Sensus: Administração, Londrina, v. 1, n. 1, p. 1-87, jan./jun. 2011

CHIZZOTTI, A. A pesquisa qualitativa em ciências humanas e sociais: evolução e desafios. Revista Portuguesa de Educação, Braga (Portugal), v.16 n.2 p.221-236, 2003.

CODO, W. Um diagnóstico do trabalho: em busca do prazer. In: TAMAYO, A.J; ANDRADE, B.; CODÓ, W. Trabalho, organizações e cultura. São Paulo: Cooperativa de Autores Associados, 1997.

COSTA, F. N. Comportamentos dos investidores: do homo economicus ao homo pragmaticus. São Paulo, 2009, 36 p. Texto para Discussão - Instituto de Economia da UNICAMP.

COUTINHO, M. C. Sentidos do trabalho contemporâneo: as trajetórias identitárias como estratégia de investigação. Cadernos de Psicologia Social do Trabalho, v. 12, n. 2, p. 189 202, dez. 2009.

DOURADO, D. P.; HOLANDA, L. A.; SILVA, M. M. M.; BISPO, D. A. Sobre o sentido do trabalho fora do enclave de mercado. Cadernos EBAPE, Rio de Janeiro, v. 7, n 2, artigo 10, Rio de Janeiro, p. 349 - 367, jun. 2009.

DUBAR, C. A socialização: construção das identidades sociais e profissionais. Título original: La socialisation: construction des identités sociales et professionelles. Tradução de A. S. M. SILVA. São Paulo: Martins Fontes, 2005. 
ERDMANN, A. L.; MELLO, A. L. S. F.; MEIRELlES, B. H. S.; MARINO, S. R. A. As organizações de saúde na perspectiva da complexidade dos sistemas de cuidado. Revista Brasileira de Enfermagem, Brasília (DF), v. 57, n. 4, p. 467-471, jul./ago. 2004.

FARIA, E. M. Quem produz e quem o trabalho produz. In: LEOPARDI, M. T. et al. O processo de trabalho em saúde: organização e subjetividade. Florianópolis: Papa Livros, 1999.

FERNANDES, M. E. R. Os Paradoxos do Processo Identificatório na Trajetória de Diretores, Gerentes e Técnicos de duas Empresas Multinacionais de Tecnologia. In: ENCONTRO DA ASSOCIAÇÃO NACIONAL DE PÓS-GRADUAÇÃO E PESQUISA EM ADMINISTRAÇÃO, 34., 2009, Florianópolis. Anais... São Paulo: ANPAD, 2009, CD-ROM.

FERREIRA, A. B. H. Dicionário Aurélio Básico da língua portuguesa. Rio de Janeiro:

Nova Fronteira, 1995.

FERREIRA, M. C. Bem-estar: Equilíbrio entre a Cultura do Trabalho Prescrito e a Cultura do Trabalho Real. In TAMAYO, A. (org.) Cultura Organizacional e Saúde. São Paulo: Artmed, 2004.

FISCHER, R. M. O circulo do poder: as práticas invisíveis de sujeição nas organizações complexas. In: FLEURY, M.T.L.; FISCHER, R.M. Cultura e poder nas organizações. 2 ed. São Paulo: Atlas, 1996.

FRANCO, T. B., MERHY, E. E. Cartografias do Trabalho e Cuidado em Saúde. Revista Tempus Actas de Saúde Coletiva. Brasília (DF), v. 6, n.2, p.151-163, abr. 2012.

FRANCO, T. B.; MERHY, E. E. Mapas analíticos: um olhar sobre a organização e seus processos de trabalho. Rio de Janeiro; 2007. 14 p. Texto da Linha de Pesquisa: Micropolítica do Trabalho e o Cuidado em Saúde da Universidade Federal do Rio de Janeiro - UFRJ. Disponível em: http://www.medicina.ufrj.br/micropolitica/textos/mapas_analiticos.pdf. Acesso em: 15 de outubro de 2013

GOULART, P. M. O significado do trabalho: delimitações teóricas (1955-2006). Cadernos de Psicologia Social do Trabalho, São Paulo, v. 12, n. 1, p. 47-55, nov. 2009.

GUTIERREZ, B. A. O.; CIAMPONE, M. H. T. Profissionais de enfermagem frente ao processo de morte em unidades de terapia intensiva. Revista Acta Paulista de Enfermagem, São Paulo, v. 19, n. 4, p. 456 - 461, oct./dez. 2006.

HACKMAN, J. R.; OLDHAM, G. R. Development of the Job Diagnostic Survey. Journal of Applied Psychology, Washington, v. 60, n. 2, p. 159-170, abr. 1975.

HRTN - Hospital Risoleta Tolentino Neves. Disponível em: http://www.hrtn.fundep.ufmg.br/index.php?option=com_content\&task=view\&id=159\&Itemid $=86$. Acesso em: 14 set. 2013.

KONDER, L. O que é dialética. 25 ed. São Paulo: Brasiliense, 1981. 
LEAL, R. S. Subjetividade e Objetividade: o Equilíbrio da Racionalidade nos Estudos Organizacionais. Revista Gestão e Planejamento, Salvador, v. 6, n 11, p. 61-74, jan./jun. 2005.

LEITE, M. A.; VILA, V. S. C. Dificuldades vivenciadas pela equipe multiprofissional na unidade de terapia intensiva. Revista Latino-Americana de Enfermagem, Ribeirão Preto, v. 13, n. 2 , p. 145 - 150, mar./ abr. 2005.

LUCENA, A.F; CROSSETTI, M.G.O. Significado do cuidar na unidade de terapia intensiva. Revista Gaúcha de Enfermagem, Porto Alegre, v. 25, n.2, p. 243 - 256, ago. 2004.

MALTA, D. C.; MERHY, E. E.. A micropolítica do processo de trabalho em saúde - revendo alguns conceitos. Revista Mineira de Enfermagem, Belo Horizonte, v. 7, n. 1, p. 61-66, jan./jul. 2003.

MARX, K. O Capital. Edição resumida por J. BORCHARDT. Tradução de R. A. SCHMIDT. 7 ed. Rio de Janeiro: LTC, 1982.

MATOS, E.; PIRES, D. E. P.; RAMOS, F. R. S. Expressões da subjetividade no trabalho de equipes Interdisciplinares de saúde. Revista Mineira de Enfermagem, Belo Horizonte, v. 14, n. 1, p. 59-67, jan./mar. 2010.

MELO JÚNIR, J.A.C.C. O trabalho e seus críticos: um debate teórico. Fênix - Revista de História e Estudos Culturais. Rio de Janeiro, v. 5, n. 3, p. 1- 20, jul./ago./set. 2008 Vol.

MERHY, E.E. Em busca do tempo perdido: a micropolítica do trabalho vivo em saúde. In: MERHY, E.E.; ONOCKO, R. Agir em Saúde: um desafio para o público. São Paulo: Hucitec, 1997.

MERHY, E. E.; FRANCO, T. B. Trabalho em Saúde. In: PEREIRA, I. B.; LIMA, J. C. F. Dicionário Da Educação Profissional Em Saúde. 2 ed. Rio de Janeiro: EPSJV, 2008.

MERHY, E. E.; FRANCO, T. B. Por uma Composição Técnica do Trabalho em saúde centrada no campo relacional e nas tecnologias leves. Apontando mudanças para os modelos tecno-assistenciais. Saúde em Debate, Rio de Janeiro, v. 27, n. 65, p. 316-323, set./dez. 2003.

MERHY, E. E.; FRANCO, T. B. Reestruturação produtiva e transição tecnológica na saúde. São Paulo: Hucitec, 1997.

MINAYO, M.C.S. O desafio do conhecimento: pesquisa qualitativa em saúde. 8. ed. São Paulo: Hucitec, 2010.

MORIN, E. Qu'est-ce qui donne un sens au travail? Objectif Prévention, Montréal, v. 31, n. 2, p. $10-14,2008$.

MORIN, E. The meaning of work in modern times. In: WORLD CONGRESS ON HUMAN RESOURCES MANAGEMENT, 10., 2004, Rio de Janeiro. Conference..., Rio de Janeiro: WFPMA, 2004, p. $1-12$. 
MORIN, E. Os sentidos do trabalho. In: WOOD, T. Gestão empresarial: O fator humano. São Paulo: Atlas, 2002.

MORIN, E. Os sentidos do trabalho. Revista de Administração de Empresas, São Paulo, v. 41, n. 3, p. 8-19, jul./set. 2001.

MORIN, E; GAGNÉ, C. Donner un sens au travail: promouvoir le bien-être psychologique. Montréal; 2009. 20p. Report. Disponível em: http://www.irsst.qc.ca/media/documents/PubIRSST/R-624.pdf . Acesso em: 23 de outubro de 2013.

MORIN, E.; TONELLI, M. J.; PLIOPAS, A. L. V O trabalho e seus sentidos. Revista Psicologia e Sociedade, Belo Horizonte, v. 19, n. 1, p. 47-56, jun. 2007. Edição Especial

MORITZ, R. D. Os profissionais de saúde diante da morte e do morrer. Revista Bioética, Brasília, v. 13, n. 2, 2005.

MOW, International Research Team. The meaning of working. New York : Academic Press, 1987.

OLIVEIRA, S. R.; PICCININI, V. C. Trabalho, saúde e cooperativismo: os sentidos do trabalho para os dentistas filiados à UNIODONTO. Revista da ABET, Curitiba, v. 5, n. 2, p. 190-219, 2005.

PAGÉS, M. et al. O poder das organizações. Tradução de C. P. TAVARES e S. S. FAVATTI. São Paulo: Atlas. 1987.

PESSOA, A. R. Histórias em Quadrinhos: Um meio Intermidiático. São Paulo, 2010. Disponível em: http://www.bocc.ubi.pt/pag/pessoa-alberto-historias-em-quadradinhos.pdf. Acesso em: 17 de outubro de 2012.

PINHO, M. C. G.. Trabalho em equipe de saúde: limites e possibilidades de atuação eficaz. Ciência e Cognição, Rio de Janeiro, v. 08, n. 2, p. 68-87, ago. 2006.

PIRES, D. E. P. Reestruturação produtiva e trabalho em Saúde no Brasil. 2 ed. São Paulo: Annablume; 2008.

PUENTE-PALACIOS, K.; VIEIRA, R. A.; FREIRE, R. A. N. O impacto do clima no comprometimento afetivo em equipes de trabalho. Avaliação Psicológica, v. 9, n. 2, p. 311 322 , jun. 2010.

RAMMINGER, T.; NARDI, H. C. Subjetividade e trabalho: algumas contribuições conceituais de Michel Foucault. Interface - Comunicação, Saúde, Educação, Botucatu, v.12, n.25, p.339-346, abr./jun. 2008.

ROBBINS, S. P.; JUDGE, T. A; SOBRAL, F. Comportamento Organizacional: teoria e prática no contexto brasileiro. 14 ed, São Paulo: Pearson, 2010. 
SAFAR, P.; GRENVIK, A. Critical Care Medicine: Organizing and Staffing Intensive Care Units. American College of Chest Physicians, Dundee Road Northbrook, v. 59, n. 5, p. 535, jun. 2012.

SILVA, E. L.; CUNHA, M. V. A formação profissional no século XXI: desafios e dilemas. Revista Ciência e Informação, Brasília, v. 31, n. 3, p. 77-82, set./dez. 2002.

SILVA, R. C.; FERREIRA, M. A. Representações Sociais dos Enfermeiros sobre a Tecnologia no Ambiente da Terapia Intensiva. Revista Texto \& Contexto Enfermagem, Florianópolis, v. 18, n. 3, p. 489-497, jul./set. 2009.

SCHERER, M. D. A.; PIRES, D. E. P. A interdisciplinaridade prescrita para o trabalho da equipe de saúde da família, na percepção dos profissionais de saúde. Tempus - Actas de Saúde Coletiva, Brasília, v. 3, n. 2, p. 30-42, abr./jun. 2009.

SCHERER, M. D. A.; PIRES, D. E. P; SCHWARTZ, Y. Trabalho coletivo: um desafio para a gestão em saúde. Revista de Saúde Pública, Brasília, v. 43, n.2, p. 721-725, dez. 2009.

SIMON, J.; COLTRE, S. M. O Comprometimento Organizacional Afetivo, Instrumental E Normativo: estudo de caso de uma empresa familiar. Qualit@s Revista Eletrônica, Guarabira, v.13. n. 1, p. 4-23, 2012.

SOUZA, L. V.; SCORSOLINI-COMIN, F. Relações profissionais em Equipes de Saúde: alternativas construcionistas relacionais. Saúde e Transformação Social, Florianópolis, v.1, n.3, p.37-46, abr. 2011.

SOUZA, S. S et al. Reflexões de profissionais de saúde acerca do seu processo de trabalho. Revista Eletrônica de Enfermagem, Goiânia, v.12, n.3, p. 449-455, nov. 2010.

TOLFO, S. R; PICCININI, V. C. Sentidos e Significados do trabalho: explorando conceitos, variáveis e estudos empíricos brasileiros. Revista Psicologia e Sociedade, Porto Alegre, v. 19, n.1, p. 38-46, mai. 2007. Edição Especial.

TOLFO, S. R.; PICCININI, V. C. As melhores empresas para trabalhar no Brasil e a qualidade de vida no trabalho: disjunções entre a teoria e a prática. Revista de Administração Contemporânea, Curitiba, v. 5, n. 1, p. 165-193, jan./abr. 2001.

TURATO, E. R. Tratado de metodologia da pesquisa clínico-qualitativa: construção teórico-epistemológica, discussão comparada e aplicação nas áreas de saúde e humanas. Petrópolis: Vozes, 2003.

ULHÔA, M. L. et al. Estresse ocupacional dos trabalhadores de um Hospital Público de Belo Horizonte: um estudo de caso nos Centros de Terapia Intensiva. REGE, São Paulo, v. 18, n. 3, p. 409-426, jul./set. 2011.

VON RANDOW, R. M. Práticas gerenciais em unidades de pronto atendimento no contexto de estruturação da rede de atenção à saúde de belo horizonte. 2012. 146 p. Dissertação (Mestrado em enfermagem) - Escola de Enfermagem da Universidade Federal de Minas Gerais/UFMG, Belo Horizonte. 
YIN, R. K. Estudo de caso: planejamento e métodos. Tradução de A. THORELL. Porto Alegre: Bookman, 2010. 


\section{APÊNDICES}

\section{Apêndice A}

\section{TERMO DE CONSENTIMENTO LIVRE E ESCLARECIDO}

Gostaria de convidá-lo(a) a participar de uma pesquisa intitulada, "Os sentidos do trabalho para profissionais da saúde do CTI de um hospital universitário", a ser desenvolvida no curso de Mestrado em Enfermagem pela Universidade Federal de Minas Gerais EEUFMG. A pesquisa configura-se como uma das exigências para obtenção do título de Mestre em Enfermagem, sendo de responsabilidade de Carolina da Silva Caram, aluna regularmente matriculada no referido curso e orientada pela Professora Dr $^{\mathrm{a}}$ Maria José Menezes Brito, Professora Associada desta escola. O estudo tem por objetivo compreender o sentido do trabalho para profissionais que atuam no CTI de um hospital universitário em Belo Horizonte. Trata-se de um estudo de caso com abordagem qualitativa, em que a coleta de dados será por meio de questionário e entrevistas. Ao ser entrevistado (a) você responderá a algumas questões referentes ao trabalho na saúde e questões subjetivas acerca do trabalho que realizam na unidade. Possui risco de constrangimento advindo das entrevistas que serão minimizados garantindo o anonimato, sigilo das informações e confidencialidade delas.

Assim, mediante sua autorização, as entrevistas serão gravadas com a finalidade de assegurar a autenticidade das informações, ficando à sua disposição caso queira ouvi-la.

Sua colaboração é voluntária e o seu anonimato será garantido. Firmamos o compromisso de que as informações serão utilizadas apenas para fins desta pesquisa. Salientamos que este projeto de pesquisa foi submetido e aprovado nos Comitês de Ética e Pesquisa da UFMG (COEP/UFMG) e do Hospital cenário deste estudo. Em qualquer fase da pesquisa você poderá fazer perguntas, esclarecer dúvidas, recusar a responder as questões e ainda retirar o seu consentimento, sem nenhum ônus ou prejuízo. O não consentimento quanto a sua participação no estudo não lhe implicará em nenhum tipo de restrição institucional.

Os resultados esperados são contribuir com outros estudos sobre a temática; com o processo de trabalho, as políticas de recursos humanos e as práticas de gestão das organizações hospitalares. Se estiver de acordo favor assinar o presente Termo, dando seu consentimento para a participação da pesquisa em questão.

Prof. Dra. Maria José Menezes Brito

Carolina da Silva Caram

$\mathrm{Eu}$, portador do documento de identidade , fui informado dos objetivos desta pesquisa de maneira clara e

detalhada e esclareci minhas dúvidas. Estou ciente que a qualquer momento poderei solicitar novas informações e modificar minha decisão de participar se assim o desejar. Declaro que concordo em participar desse estudo como voluntário.

Assinatura do participante:

Belo Horizonte, I

Nome da pesquisadora: Carolina da Silva CaramTel: (31) 34224782

Orientadora: Prof. ${ }^{a} \mathrm{Dr}^{\mathrm{a}}$ Maria José Menezes Brito Tel: (31) 3409-9849

Comitê de Ética e Pesquisa da UFMG (COEP): Av. Pres. Antônio Carlos, n ${ }^{\circ}$ 6627, Unidade Administrativa I I, $2^{\circ}$ andar, sala 2005, Bairro Pampulha, Belo Horizonte/MG. CEP: 31.270901. Tel: (31) 3409-4592 
Apêndice B

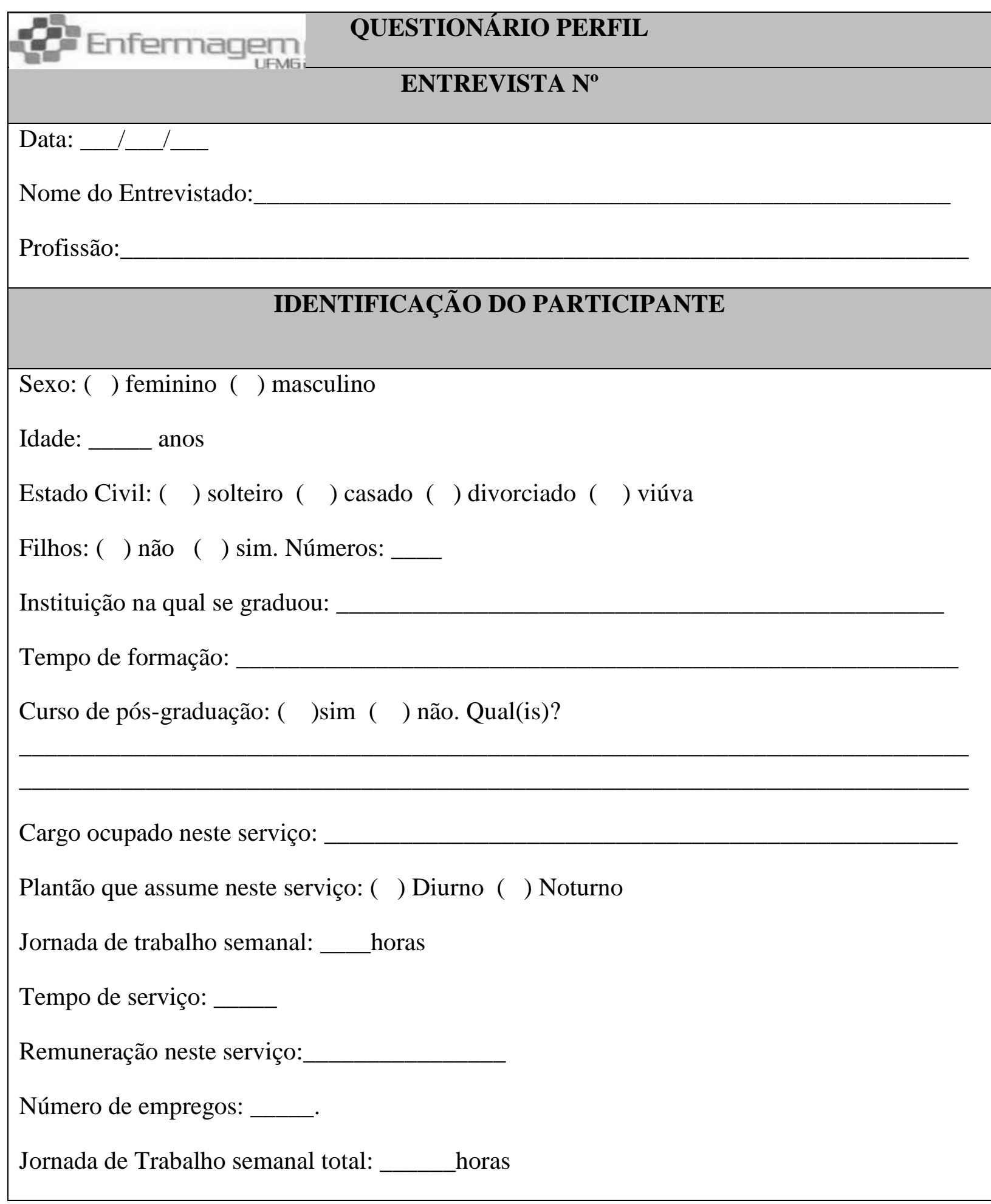




\section{Apêndice C}

\section{Enfermagem}

\section{ROTEIRO DE ENTREVISTA}

1. Fale sobre o trabalho que você realiza no CTI.

2. Fale sobre os aspectos que considera mais importantes no seu trabalho no CTI?

3. O que significa pra você trabalhar no CTI?

4. Seu ambiente de trabalho propicia sentimentos de prazer? Narre uma situação

5. Seu ambiente de trabalho propicia sentimentos de sofrimento? Narre uma situação.

6. Você mudaria algo relacionado ao seu trabalho no CTI? Fale sobre isso.

7. Continue a frase. Um trabalho ideal no CTI seria...

8. Fale sobre as principais motivações que você encontra na realização do seu trabalho no CTI.

9. O que você busca para a sua vida mediante o seu trabalho?

10. Se você parasse de trabalhar no CTI hoje do que mais sentiria falta? Fale sobre isso.

11. Se você tivesse a oportunidade de escolher um local para trabalhar você escolheria novamente o CTI? Fale sobre isso.

12. Fale sobre:
a) como o seu trabalho contribui para você mesmo.
b) como o seu trabalho contribui para a organização.
d) como o seu trabalho contribui para a sociedade. 
Apêndice D

\section{TÉCNICA DO GIBI \\ NÚMERO DA ENTREVISTA}

Selecione uma figura da revista tipo gibi que representa a seguinte afirmação para você:

"um trabalho que tem sentido..."

Recorte e cole a figura selecionada neste espaço

2.1 Comente os motivos que o levaram a escolher tal figura.

3. Selecione uma figura da revista tipo gibi que representa a seguinte afirmação para você:

"um trabalho que não tem sentido..."

Recorte e cole a figura selecionada neste espaço

3.1 Comente os motivos que o levaram a escolher tal figura. 


\section{ANEXOS}

\section{Anexo A}

\section{UNIVERSIDADE FEDERAL DE MINAS GERAIS}

\section{PARECER CONSUBSTANCIADO DO CEP}

\section{DADOS DO PROJETO DE PESQUISA}

Título da Pesquisa: Os sentidos do trabalho para profissionais da saúde do CTI de um Hospital Universitário

Pesquisador: Maria José Menezes Brito

Área Temática:

Versão: 2

CAAE: 16023313.0 .0000 .5149

Instituição Proponente: UNIVERSIDADE FEDERAL DE MINAS GERAIS

Patrocinador Principal: Financiamento Próprio

\section{DADOS DO PARECER}

Número do Parecer: 329.009

Data da Relatoria: 10/07/2013

Apresentação do Projeto:

Partindo da premissa de que as interação entre os sujeitos e as organizações determinam a dinâmica do trabalho e as relações inerentes a ela, o presente estudo pretende obter informações que facilitem a compreensão do significado dado ao trabalho em CTls por profissionais de saúde de diferentes formações e que atuam em um Hospital Universitário. Cumpre ressaltar que os autores operacionalizam o termo "sentido" como a compreensão da razão de ser dos profissionais ao realizarem seu trabalho.

A partir dessa definição, os autores pretendem avaliar a hipótese de que o profissional que atribui sentido positivo ao seu trabalho atua em consonância com os objetivos organizacionais, evitando assim, os desvios de comportamentos que comprometem a assistência à saúde.

Objetivo da Pesquisa:

Objetivo principal: Compreender os sentidos do trabalho para profissionais que atuam no CTI de um hospital universitário em Belo Horizonte.

Objetivos especificos:

Conhecer a concepção dos profissionais acerca do seu trabalho; Analisar as principais motivações para a realização do trabalho; analisar as expectativas dos profissionais em relação ao trabalho

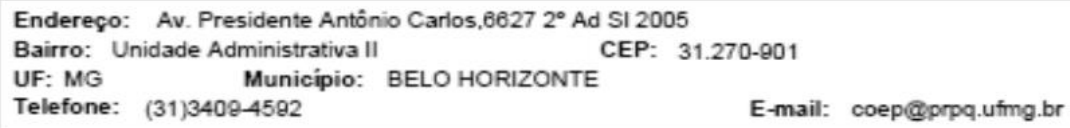




\section{UNIVERSIDADE FEDERAL DE MINAS GERAIS}

Contnuaçato do Parecer. 329.009

realizado.

Avaliação dos Riscos e Beneficios:

Riscos: possiveis constrangimentos advindos das entrevistas. Os autores sugerem entretanto que tais riscos serão minimizados garantindo o anonimato, sigilo das informações e confidencialidade das informações. Asseguram ainda que qualquer um dos participantes poderá se recusar a responder as questões ou se retirar a qualquer momento da pesquisa sem prejuizos ou danos à sua pessoa.

Benefícios: pretende-se alcançar melhorias na organização do processo de

trabalho, as políticas de recursos humanos, a prática de gestão da organização hospitalar, e possibilidade de reflexão críticas acerca da forma como os profissionais da saúde realizam e encaram o trabalho no CTI.

Comentários e Considerações sobre a Pesquisa:

O delineamento do estudo está adequado do ponto de vista conceituai e metodológico. Não há restrições do ponto de vista ético.

Considerações sobre os Termos de apresentação obrigatória:

Os termos obrigatórios foram devidamente apresentados.

Recomendações:

Termo de Consentimento foi reformulado incluindo a informação de que a não aquiescência quanto a participação no estudo não implicará em nenhum tipo de restrição institucional ao convidado. Adicionada a existência dos riscos mínimos no termo de consentimento, listados no projeto de pesquisa e a forma adotada para minimizá-los.

Conclusões ou Pendências e Lista de Inadequações:

Somos pela aprovação do projeto "Os sentidos do trabalho para profissionais da saúde do CTI de um Hospital Universitário" da pesquisadora Maria José Menezes Brito

Situação do Parecer:

Aprovado

Necessita Apreciação da CONEP:

Não

Consideraçôes Finais a critério do CEP:

Aprovado conforme parecer.

Endereço: Av. Presidente Antônio Carlos,6627 $2^{\circ}$ Ad SI 2005

Bairro: Unidade Administrativa II
UF: MG Municipio: BELO HORIZONTE

Telefone: (31)3400-4592 E-mail: coep@prpq.ufmg.br 


\section{Anexo B}
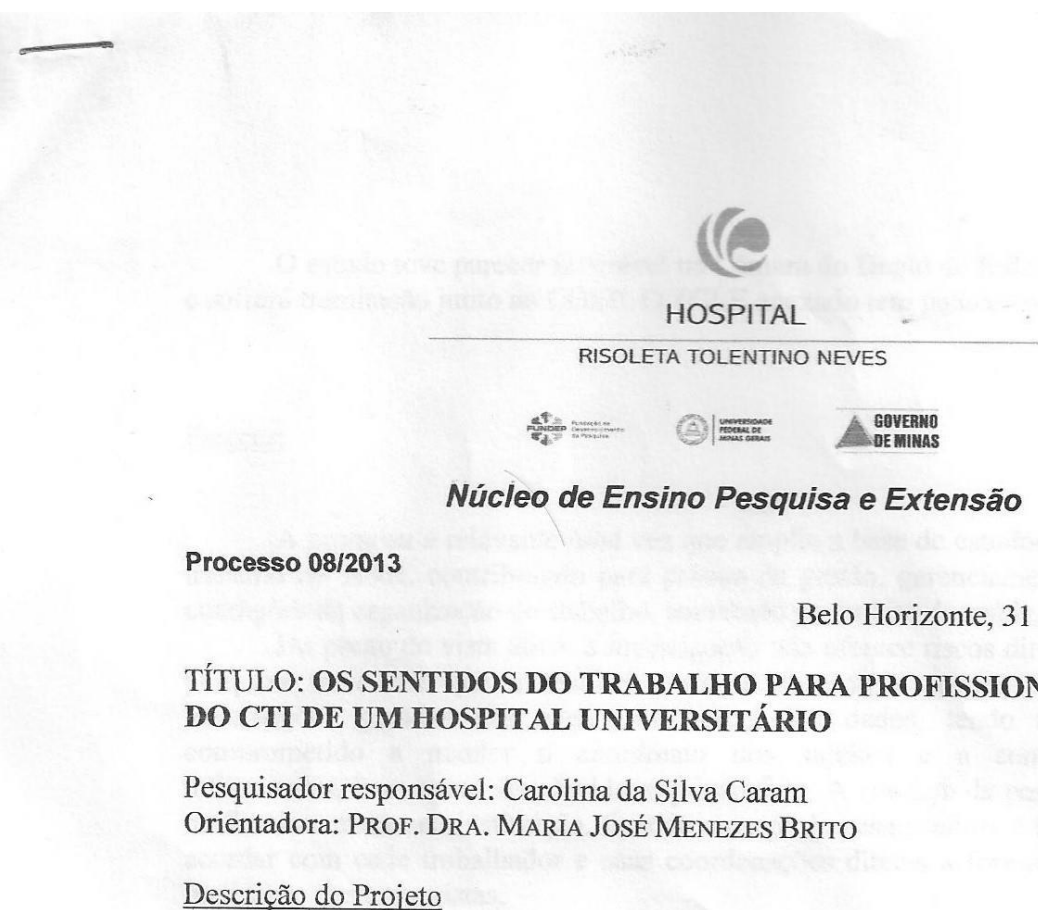

Núcleo de Ensino Pesquisa e Extensão

Processo 08/2013

Belo Horizonte, 31 de Janeiro de 2013.

\section{TÍTULO: OS SENTIDOS DO TRABALHO PARA PROFISSIONAIS DA SAÚDE DO CTI DE UM HOSPITAL UNIVERSITÁRIO}

Pesquisador responsável: Carolina da Silva Caram

Orientadora: PRof. DRA. MARIA JosÉ MENEZES BRITO

\section{Descrição do Projeto}

O projeto de mestrado supracitado propõe a partir de um estudo de caso conhecer os sentidos do trabalho para os profissionais do CTI, tomando suas concepções e motivações ocupacionais em diferentes dimensões, individual, social e organizacional.

Para empreender essa investigação a pesquisadora usará três fontes de levantamento de dados que possibilitam uma triangulação da análise. Sendo assim, essa coleta de dados se dará em três etapas: $1^{\circ}$ Aplicação de questionário de perfil do trabalhador $2^{\circ}$ Realização de entrevistas gravadas com roteiro semi-estruturado para definição de elementos sobre o trabalho 3 - Aplicação da técnica do gibi (técnica lúdica que envolve a escolha de figuras em um gibi padrão, aplicado para todos os sujeitos da amostra. Técnica que instrumentaliza o discurso do trabalhador para representação dos sentidos produzidos). Essa fase também será gravada em áudio. A coleta de dados será realizada de Março a Maio de 2013 e o tratamento das informações realizado com uso da técnica de análise de conteúdo de Bardin( Método que relaciona estruturas semânticas com estruturas sociológicas dos enunciados recolhidos na pesquisa).

A amostra de estudo será composta por profissionais do CTI com mais de um ano de trabalho na unidade, não feristas e que pertencem a categorias que tem contato assistencial direto com a paciente. São elas: enfermagem, medicina, técnico de enfermagem, fisioterapia, nutrição, psicologia. O tempo de trabalho para inclusão amostral é justificado pela base material histórica que o percurso profissional confere a experiência do sujeito. Por via de tabulação no programa Excel șerá feita uma inclusão aleatória das categorias prqfíssionais com base em todos os plantões, diurno e noturno. Com exceção do psicólogo e nutricionista que tem apenas um profissional lotado na unidade. 